\title{
The Socio-economic Position of Testators
}

\section{Social Characteristics of the Late Medieval City}

In the 1420s, the Bishop of Poznan, Stanisław Ciołek, wrote the following, in a song of praise to Krakow: "City of Krakow, your citizens united" (Cracovia civitas, Te civium unitas). ${ }^{1}$ Later, an anonymous fifteenth-century preacher added that if burghers did not create unity, they should not be called burghers, but rather peasants, arguing that Christ, as a burgher himself, greatly valued unitas. $^{2}$ This ideal of unity among the citizenry was also commonly found among the members of the urban municipality, especially in regards to outside groups or foreign influences - both inside and outside the city walls. When correspondence was exchanged or negotiations conducted with other cities, and when homage was paid to the majesty of the royal power, the Krakow community spoke formally with one voice. For example, in 1425 the city swore an oath of allegiance to King Władysław Jagiełło which begins Nos consules et tota civitas Cracoviensis... ${ }^{3}$ Yet differences of social and financial position, occupation, ethnicity, family line, place of origin and cultural capital were visible almost everywhere. These differences defined the needs and opportunities of the city's inhabitants, and thus their social and religious practices, as well.

In a community, various factors affect the unity and sense of collective identity of its members. The first of these is certainly the feeling of power that derives from belonging to this community. The bigger, richer and stronger the community, the greater and stronger this feeling becomes. Belonging is here a

1 Stanisław Ciołek, Pochwała Krakowa [In Praise of Krakow] in Codex Epistolaris Vitoldi Magni Ducis Lithuanie 1376-1430, ed. Antoni Prochaska (Krakow: Acad. Literarum, 1882), 1057-1058, $1057-1058$.

2 "Et Christosomus dicit postquam rex celorum orbis terre natus est secundum carnem cepit esse concivis non villanus. Quia civitas dicitur civium unitas, quam unitatem Christus summe dilexit et nunc diligit. Unde ubicumque cives non sunt unanimes non menciuntur dici cives, sed villani, quia non sunt concordes"; as in Krzysztof Bracha, Nauczanie kaznodziejskie w Polsce późnego średniowiecza. Sermones dominicales et festivales z tzw. kolekcji Piotra z Mitostawia (Kielce: Wydawnictwo Akademii Świętokrzyskiej w Kielcach, 2007), 271.

3 For example, the city of Krakow swore an oath of allegiance to King Władysław Jagiełło, his son Władysław, and in the event of their childless deaths, to Princess Hedwig; Codex epistolaris saeculi decimi quinti, vol. 1, ed. Anatol Lewicki (Krakow: Akad. Umiejętności, 1891), no. 67 (1425).

(C) JAKUB WYSMUŁEK, 2021 | DOI:10.1163/9789004461444_004

This is an open access chapter distributed under the terms of the CC BY-NC-ND 4.0 license. 
source of happiness and pride, even if one plays a relatively marginal role in the community. As a community is weakened, one's identification with it can likewise become the source of a sense of weakness or inferiority. The cohesiveness of any given community is maintained by collective rituals celebrating its unity and hierarchies. These include shared holiday celebrations, processions that provide an opportunity to manifest one's identification with the community and position within it, ${ }^{4}$ and traditional feasts and gatherings that play an elementary, archaic role, of inducting individuals into a circle of friends, family, clan or a wider social group. These shared celebrations also serve a most important function; they are a means of sustaining memoria - the memory of a community's history and its deceased members. ${ }^{5}$ On the other hand, community is first built through mutual utility - through giving and receiving. In this way, a network of commitments is created; that is, bonds that join people together by means of the eternal principle of reciprocity and the debt an indebted individual owes to their benefactor. In traditional societies, a donation has not so much an economic dimension as a social, moral and religious one. ${ }^{6}$ Like a will, a larger pious foundation is a form of gift, if not to the community as a whole, then at least to a specific group of people. It is a means of identifying with the community, a proof of one's trust in it and concern for it, and a testament to one's hope that this generous gift will be repaid. For giving is never a sign of indifference or neutral in character. It creates a social bond, but it is also a form of symbolic violence. ${ }^{7}$ One must either succumb to the expectation of reciprocity or reject the gift, which is seen as an insult; an affront to the donor and a renunciation of friendship.

4 "In other words, a procession, with its established order, symbolic stations, songs and a whole scenario, expressed the most important concepts of urban theology, and communicated to its participants that the city was a common good, that it was - according to a metaphor by Wilhelm of Auvergne - a shared creation of free and united citizens who lived in a wonderful environment by means of mutual agreement."; Jacques Rossiaud, Mieszczanin i życie w mieście, in Cztowiek średniowiecza, ed. Jacques Le Goff, trans.. Maria Radożycka-Paoletti (Warszawa-Gdańsk: Świat Ksiązki, 1996), 225 (J. Rossiaud, Le Citadin, "L'Homme medieval," ed. Jacques Le Goff, Seuil 1989); cf. Hanna Zaremska, "Procesje Bożego Ciała w Krakowie w XIV-XVI wieku," in Kultura elitarna a kultura masowa w Polsce późnego średniowiecza, ed. Bronisław Geremek (Wrocław: Zakład Narodowy im. Ossolińskich, 1978), 25-40, 25-40.

5 Otto Gerhard Oexle, "Memoria und Memorialüberlieferung im frühen Mittelalter," Frühmittelalterliche Studien, vol. 10, 1976; idem, "Die Gegenwart der Lebenden und der Toten. Gedanken über Memoria," in Gedächtnis, das Gemeinschaft stiftet, ed. Karl Schmid (München-Zürich: Verl. Schnell \& Steiner, 1985).

6 Marcel Mauss, The Gift: The Form and Reason for Exchange in Archaic Societies, trans. W.D. Halls (New York: Routledge, 199 o (1950)).

7 Pierre Bourdieu, The Logic of Practice (Cambridge: Cambridge University Press, 1990), 122-134. 
People's place in the community in which they live, their position and prestige are partly a matter of perspective. Everyone evaluates himself or herself from the point of view of his or her own values, prestige and power. This position is evaluated differently by one's own family, neighbours, members of social or professional groups to which one belongs, and members of other communities. In culturally homogeneous and traditional rural communities, due to the limited number of members, similarities in the way they live and work, and their fundamental self-sufficiency, there is no need to create more extensive social structures than those determined by personal prestige and wealth. A fundamental feature of a large city in almost every age is that new immigrants coming from smaller towns and the countryside had to face its social, professional, financial, class, and even ethnic, linguistic and religious diversity. In this much larger and much more complex community, a person's place was largely determined by his belonging to one or more communities that were either secular or religious in nature (and most often containing elements from both). These groups were of a formal, corporate or devotional character, or based on informal ties of friendship, neighborhood, kinship and personal interests, and comprised the complex social structure of the medieval city. The principle of group solidarity, and the identity based on it, did not necessarily differ much from that already found in rural environments. In the city, however, unlike in rural areas, social groups were more often voluntary associations than natural communities. ${ }^{8}$ Where wealth is based on money and not on land inherited, where personal activity is more important than inherited honours, people have a greater part to play in making personal decisions, selecting which groups they wish to be members of, and defining their role within these groups.

The medieval city was also a world of paradoxes and contradictions. In their search for sources of authority, its inhabitants often turned to 'old customs,' even though modernizing forces were considerably stronger in urban areas. In the city, more than anywhere else, money meant power, even as poverty was venerated, especially voluntary poverty. Finally, in a relatively small area lived a community in which there were enormous income disparities, where

8 In the well-known division between Community (Gemeinschaft) and Society (Gesellschaft) Ferdinand Tönnies referred to the earlier work of J.G. Bluntschli and R. Bradter: “...Wherever urban culture flourishes, 'Society' also appears as its indispensable medium. Country people know little of it. On the other hand, everyone who praises rural life has pointed to the fact that people there have a stronger and livelier sense of Community. Community means genuine, enduring life together, whereas Society is a transient and superficial thing. Thus Gemeinschaft must be understood as a living organism in its own right, while Gesellschaft is a mechanical aggregate and artefact.", Ferdinand Tönnies, Community and Civil Society, ed. Jose Harris (Cambridge: Cambridge University Press, 2001), 19 
alongside rich merchants who lent money to the king, lived impoverished people with very modest resources. Nevertheless, in the urban communitas the evangelical ideal of modesty and the notion of the equality of its members were still alive.

How, then, in this complex social structure, in which the determinants of position were such disparate values as humility, charity and piety, on the one hand, and ostentatious wealth and wasteful consumption, on the other, can we designate the place of those who chose to write a will? Does the social standing of the testators explain how they used wills to express, maintain or advance their own position?

It seems the answers should be sought both in the social categories used by medieval burghers and in the meaning they assigned to them. The preserved sources may bring us closer to an understanding of the structure of the social and cultural groups that included medieval Krakovian testators.

Wills are rarely used as sources in research on urban societies. This is due to a number of methodological problems, the most important of which are undoubtedly their diverse nature and their unrepresentativeness in relation to urban society as a whole. Yet, they contain a great deal of valuable information about the property and family relations of burghers that is found nowhere else. In the present chapter, devoted to an analysis of the groups to which Krakow testators belonged, an attempt has been made to overcome these difficulties in order to make the most of the potential inherent in these sources. At the same time, understanding who the people were who decided to write their acts of last will should also help us better understand their role and the reasons why these documents were written.

When describing urban society, historians often refer to a classic tripartite model, comprising the patricians, the common citizens (in Polish - pospólstwo), and plebeians (plebs) - the poorest social stratum in the city. ${ }^{9}$ Of these three

9 Andrzej Karpiński, Pauperes. O mieszkańcach Warszawy XVI i XVII wieku (Warszawa: Państwowe Wydawnictwo Naukowe, 1983); Jan Ptaśnik, Miasta i mieszczaństwo w dawnej Polsce (Warszawa: Państwowe Wydawnictwo Naukowe, 1949), 87; Maria Bogucka, Henryk Samsonowicz, Dzieje miast i mieszczaństwa w Polsce przedrozbiorowej (Wrocław-WarszawaKrakow: Zakład Narodowy im. Ossolińskich, 1986), 138-156; Jacek Wiesiołowski, "Biedni, bogaci, przeciętni. Stratyfikacja społeczeństwa polskiego w końcu XV w., in Biedni i bogaci. Studia z dziejów spoteczeństwa i kultury ofiarowane Bronisławowi Geremkowi w sześćdziesiąta rocznicę urodzin (Warszawa: Państwowe Wydawnictwo Naukowe, 1992), 145-154. 
groups, however, only the common citizens has any foundation in the sources, as a translation of the Latin expression communitas civium - civic community. ${ }^{10}$ Synonyms are the Polish terms komuna (commune) and gmina (community) derived from the German word gemeynde, which has the same meaning. The concepts of patrician and plebeian were borrowed from ancient Rome - and thus far from the realities of medieval cities - where conflicts often broke out between the privileged and politically disadvantaged strata of society. ${ }^{11}$ These are therefore not terms used by medieval townsmen themselves. In reality, a basic division between 'us and them' dominated, ${ }^{12}$ with any collectivity being defined by its opposition to some other group. Roman Czaja rightly points out that most information about how the social system was perceived was connected with social conflicts. ${ }^{13}$ When a municipality had to deal with people from outside it, such as representatives of other cities, states or territorial authorities, it acted as a homogeneous community of citizens, as a communitas. However, when conflicts broke out within the community, it usually broke down into two camps, a community of citizens (in German gancze gemeyne) and councillors exercising power over them (di libin herren), as was the case after the anti-Jewish pogrom of $1407 .{ }^{14}$ Earlier, in 1368 , when the municipal council was accused of mismanaging the finances of the community, and its citizens demanded a means to control the municipal authorities, Casimir III the Great ordered the community to elect representatives to the council, half from craftsmen (in Latin a populo mechanico) and half from the commonalty and merchants (a populo civili ac mercatorum). ${ }^{15}$ In this case, it seems that the conflict was between craftsmen and merchants, as it had been in 1418, when as a result of a complaint from the city community (in German gemeynde),

$10 \quad$ Jan Ptaśnik, Miasta i mieszczaństwo, 87.

11 "In 1516 Christoph Scheuerl (1481-1542), a lawyer and humanist, used the Roman term 'patricia' to accentuate the antiquity of the families ruling Nuremberg. In the seventeenth century, the term 'Patriciat' became widely used in Germany to refer to the people who ruled cities, and in the mid-nineteenth century the term was also used to refer to powerful elites in medieval cities."; Roman Czaja, Grupy rządzace w miastach nadbattyckich w średniowieczu (Toruń: Wydawnictwo Naukowe Uniwersytetu Mikołaja Kopernika, 2008), 18.

Ludwik Stomma, Od 'czarnej legendy' do kategorii 'swój - obcy,' in idem, Antropologia kultury wsi polskiej XIX wieku oraz wybrane eseje (Łódź: P. Dopierała, 2002), 40.

13 Roman Czaja, Grupy rzadzace, 66-67.

14 Hanna Zaremska, Żydzi w średniowiecznej Polsce. Gmina krakowska (Warszawa: Instytut Historii PAN, 2011), 471. Jan Ptaśnik, Miasta i mieszczaństwo, 89; Marcin Starzyński, Krakowska rada miejska w średniowieczu (Krakow: "Societas Vistulana," 2010), 68. 
a special, 16-person organ was established at the request of King Władysław Jagiełło to consult the council, consisting of eight representatives of merchants and eight representatives of Krakow's guilds (achte von deme Kaufmanne und achte von den Czechen) ${ }^{16}$ Without the consent of these representatives of the community, the council had no right to issue or impose new taxes, and had to report to them on the city's finances. ${ }^{17} \mathrm{~A}$ similar symbolic division of the urban community occurred in 1462, after the murder of Andrew Tęczyński, when his brother and Castellan of Krakow, John Tęczyński, named as guilty parties both members of the municipal council and representatives of the community, i.e. senior merchants and craftsmen (universum consulatum cum senioribus mercatorum et mechanicorum civitatis citarifecit). ${ }^{18}$

Among the basic symbolic divisions used by people at that time was the opposition between the urban municipality and an increasingly independent municipal council - that is between the rulers and the ruled. Another was a division within the communitas based on profession - between merchants and craftsmen, or those whose work involved bookkeeping and trade, and those who worked with their hands. Although the difference between a merchant engaged in international trade and a market stallholder was as great as the difference between a goldsmith and a local tanner, these basic distinctions were considered functional by contemporaries. Inaccurate as they may be, as models which shaped the popular imagination and social expectations of the time, it is important we take them seriously.

In Middle Ages, an occupation involving trade was associated with the intellect and accounting, while the crafts were seen primarily as forms of physical labour. Along with the disparities in the economic capital, these differing social attitudes towards specific types of work and the practices they involved influenced the social value assigned to them. The increasing employment of accounting and written culture among members of the merchant class and the nature of their work, which required the establishment of trading companies, frequent travel, dealing with money and managing financial affairs, and cooperating with people whose social class (estate) or status differed from their own, resulted in the development of a new way of thinking - a merchant's mentality - among this social class. This mentality was characterized by an ability to calculate and plan, to manage people and goods, and to participate

\footnotetext{
16 KDMK, vol. I, no. 111.

17 Jan Ptaśnik, Miasta i mieszczaństwo, 91; Marcin Starzyński, Krakowska rada, 79.

18 Codex epistolaris saeculi decimi quinti, vol. 2, ed. Anatol Lewicki (Krakow: Akad. Umiejętności, 1891), 214.
} 
in the written culture. ${ }^{19}$ At the same time, the merchant class was becoming increasingly prosperous, with ever more wealth concentrated in their hands. These factors greatly influenced the adoption and spread of writing wills among the merchant class, who now emulated members of the highest social strata in the city in drawing up acts of last will and creating foundations.

The craftsman's way of thinking was probably much more 'local-collectivist' in nature. After a journeyman completed his 'journeyman years' (wanderjahre) and chose a city in which to settle, he usually stayed there, becoming part of the local parish, guild and neighborhood structures. Both the limited prospects for social advancement offered by working in a small craft workshop and a low level of involvement in written culture caused craftsmen to be closely tied to a specific part of the urban communitas. Based on the differences between these characterological types, it can be said that while the merchant sought to emphasize his own personal social position and increase the distance between himself and other inhabitants of the city, medieval urban craftsmen were guided by the ideals of moderation and equality among the burgher class. ${ }^{20}$ Nevertheless, influenced by the practices of the upper classes, over time the practice of writing a will came to be seen as a proper way to bid farewell to loved ones and to the temporal world, and became a common practice among Krakow's craftsmen too. ${ }^{21}$

The value of structural models of urban communities, like those above, should not be underestimated, as they also express the manner in which particular social groups conceived of themselves and others. Moreover, the way in which a community and its boundaries were defined affected how power was exercised in the city and who was denied this privilege. We can expect that members of the ruling elite tended to think more often in terms of the interests

19 Agnieszka Bartoszewicz, Piśmienność mieszczańska, 240-267; eadem, "Piśmienność mieszczańska w poźnośredniowiecznej Polsce," in Historia spoteczna późnego średniowiecza. Nowe badania, ed. Sławomir Gawlas (Warszawa: DiG, 2011), 275-292; Jerzy Kaliszuk, Przemiany spotecznych funkcji pisma w późnym średniowieczu. Programy badawcze i ich rezultaty, in ibidem, 169-188; vol. Jurek, Pismo w życiu spotecznym Polski późnego średniowiecza, in ibidem, 203-232.

20 Aron J. Gurevich, Kupiec, in Cztowiek średniowiecza, 323-331 (A. J. Gurevich, Le Marchand, "L'Homme medieval," ed. Jacques Le Goff, Seuil 1989); Jacek Wiesiołowski, Socjotopografia późnośredniowiecznego Poznania (Poznan: Państwowe Wydawn. Nauk., 1997), 29.

"It is hard to deny the fact that lower-status groups often imitated the cultural practices of higher status groups. Explaining this imitation is rather more difficult. The lower groups may have done this because they wanted to rise socially, or to appear to have risen socially, because they accepted the 'cultural hegemony' of the upper classes. On the other hand, they may have imitated the habits of their so-called 'betters' as an affirmation of equity with them.", Peter Burke, Popular Culture in Early Modern Europe, New York, Ashgate 2009, 15. 
of the communitas as a whole as well as to act in ways that enhanced their own prestige and that of their family. ${ }^{22}$ Such actions included making generous bequests to city churches, especially for the founding of altars, perpetual masses, and private chapels, which not only commemorated the founder and his family, but also served the entire community. On the other hand, Krakovian burghers made pious bequests for work that served the public good, including the maintenance of city roads, bridges and city walls, which reveal something about the sacred dimension of the city, the urban community and its institutions. ${ }^{23}$ The activity of most burghers, who were prevented from participation in the broader political life of the municipality, was focused instead on concerns of smaller social groups functioning within the urban community, such as their immediate family, guilds, fraternities, and their neighborhood and parish communities. This narrower field of social contacts, limited financial means, and the craftsman's ideals of moderation and equality meant that those institutions closest to the burghers were the main beneficiaries of the provisions of their last wills.

The changes taking place in urban culture during the late Middle Ages resulted in the social elevation of the professions of the merchant and craftsman. The merchant profession, which had been earlier burdened by an association with the sin of usury, now acquired social and religious acceptance. ${ }^{24}$ As the concept arose of profit as 'compensation' for the merchant who lent money for his lost time and the risk he assumed, monetary transactions lost their previous, unambiguously negative, connotation. Belief in Purgatory, and the resulting conviction that it was possible to actively seek salvation through the prayerful support of others, led to the development of various forms of charitable activity. ${ }^{25}$ In the words of historian Jacques Le Goff, "[i]t is also clear that, in parallel with a certain social and spiritual promotion of the merchant, the management of money benefited from a shift in the ideas and practices of the Church which, it seems, wished to assist the people of the Middle Ages in their desire to safeguard their money and their lives, that is, both their earthly

22 Janusz Sztumski, Elity - ich miejsce i rola w spoteczeństwie (Katowice: “Śląsk," 1997), 45-46.

23 Marek Słoń, Religijność komunalna $w$ Europie środkowej późnego średniowiecza, in Zbožnost středověku, ed. Martin Nodl, Krzysztof Bracha, Jan Hrdina, Paweł Kras (Praha: Filosofia, 2007) (Colloquia mediaevalia Pragensia, 6), 9-21.

24 Jacques Le Goff, Money and the Middle Ages (Cambridge: Cambridge University Press, 2012), 20-22.

25 "It was manifested in special care paid to the body which, like the body of the suffering Christ, was destined to rise from the dead"; ibidem, 99; cf. Stanisław Bylina, Cztowiek $i$ zaświaty. Wizje kar pośmiertnych w Polsce średniowiecznej (Warszawa: Instytut Historii PAN, 1992), 115-135. 
wealth and their eternal salvation."26 The growing importance of money both in the everyday life of the city's inhabitants and in the policies pursued by the rulers caused property to become an increasingly important (though still not the sole) determinant of one's social position. From that time on, the amount of property one owned, and thus the urban tax revenue it generated, differentiated the city's inhabitants into distinct categories with different obligations towards the urban community.

Physical labour, previously seen as a punishment - a consequence of original sin - underwent a similar evolution in the late Middle Ages. A man who worked in a workshop with his hands became a disciple of both St. Joseph and Jesus himself, who was supposed to have worked as a carpenter in his youth. Church teachings about God's creation of the world prompted comparisons with the heavy burden of human fate: "The man who worked thus became a co-worker with God in his construction of a world which struggled to live up to the expectations of its Creator."27 Guild organizations, which became increasingly prevalent in the fourteenth and especially fifteenth centuries in Krakow, $^{28}$ not only oversaw the work of craftsmen and organized their social life, but also provided a strong base of support for enhancing the social prestige of their members. The larger and stronger the guilds were, the greater the importance of their members in the city. ${ }^{29}$ They provided a link between the city authorities, dominated by merchants, and the internally diversified community of craftsmen. It is therefore not surprising that prestigious, wellestablished guild masters were chosen by testators to act as executors of their wills or to assume the role of guardians for their underage children; moreover, in some cases, testators chose to have their last wills attested before Krakovian

\footnotetext{
26 Jacques Le Goff, Money and the Middle Ages, 149.

27 Ibidem, 71.

28 Jerzy Wyrozumski, Dzieje Krakowa. Krakow do schytku wieków średnich (Krakow: Wydawnictwo Literackie, 1992), 331-371; Hanna Zaremska, Bractwa w średniowiecznym Krakowie. Studium form spotecznych życia religijnego (Wrocław-Warszawa-Krakow: Instytut Historii PAN, 1977), 24-30.

29 Mateusz Goliński, Socjotopografia późnośredniowiecznego Wrocławia (Wrocław: Wydawn. Uniwersytetu Wrocławskiego, 1997), 463; Jerzy Wyrozumski, Dzieje Krakowa, 331-371; Feliks Kiryk, Porządek cechowy w lokacyjnym Krakowie, in Krakow. Studia z dziejów miasta, ed. Jerzy Rajman (Krakow: Wydawn. Nauk. Akademii Pedagogicznej, 2007), 76-86; Zdzisław Noga, Grupy zawodowe i przeptywy międzygrupowe w Krakowie i miastach województwa Krakowskiego w średniowieczu, in Cztowiek w średniowieczu, ed. Alicja Szymczakowa (Łódź: Wydawnictwo Uniwersytetu Łódzkiego, 2009), 253-263; Stanisław Herbst, Toruńskie cechy rzemieślnicze. Zarys przeszłości (Toruń: Nakładem Cechów toruńskich, 1933); Henryk Samsonowicz, "Cechy rzemieślnicze w średniowiecznej Polsce. Mity i rzeczywistość," PH, vol. 75, 1984, no. 2, 551-567.
} 
craftsmen. In the latter case, the craftsmen's role was formally limited to being witnesses to the transmission of the dying person's last will, though their status as senior guild members was undoubtedly an additional guarantor of the will's implementation. ${ }^{30}$

Apart from merchants (including stallholders) and craftsmen, there was a third, broad but fairly elusive, category of city inhabitant - the urban poor. ${ }^{31}$ Their numbers can only be generally estimated, and they were usually not actively involved in the local community. They did not own real estate in the city, and were tied to it only insofar as they could find a way to support themselves there. However, when their economic situation or that of the city deteriorated, or when unforeseen political or social circumstances arose, it was easy for them to leave the city walls, and either return to their home villages and towns, or move on in search of success in other large urban centres. This habit made them appear like a liquid mass of outsiders in the eyes of the city and its authorities. Of course, the status of a guild journeyman was different from that of an unskilled worker or a maid, or that of a beggar, thief or prostitute. It seems, however, that the social bonds between the poor were stronger than those tying them to other citizens of the city with whom and for whom they worked, not so much due to the occupations they were engaged in, but perhaps above all because of their lack of material wealth. ${ }^{32}$ Due to their low social status, they were also excluded from the burgher culture that was forming, as well as its ethic, social order and the forms of piety associated with it. ${ }^{33} \mathrm{~A}$ will was a tool allowing one to dispose of one's property, and thus to maintain control over its fate, even after one's death. A lack of means and the costs associated with making a will economically excluded broad groups of

$30 \quad$ CONS. 428, fol. 466 (1443); cons. 429, fol. 543 (1475); LT, fol. 133-134 (1482); as well as, for example, the will of Emerancza Długoszowa of 1508; The National Archives in Krakow, Wills and testaments, ms 779 .

"Therefore, tax registers do not include those permanent citizens of cities who did not enjoy burgher privileges, i.e.: apprentices, students, servants, hired workers, beggars and others who did not own property. Thus, municipal tax registers leave out a significant part of the urban population - the poor, who, for example, constituted $16 \%$ of Hamburg inhabitants in $1451,20 \%$ in $1487,20 \%$, and $24 \%$ in 1538 . It was discovered that at the turn of the fourteenth and fifteenth centuries only about $20 \%$ of the inhabitants of the Baltic cities had burgher privileges."; Antoni Czacharowski, "Ze studiów nad strukturą społeczną mieszczaństwa toruńskiego na przełomie XIV/XV wieku," Acta Universitatis Nicolai Copernici: Historia 9 (1973), 90.

Bronisław Geremek, Litość i szubienica. Dzieje nędzy i mitosierdzia (Warszawa: Czytelnik, 1989), 74-86.

33 Norbert Schindler, Ludzie prości, ludzie niepokorni... Kultura ludowa w początkach dziejów nowożytnych, trans. Barbara Ostrowska (Warszawa: Wiedza Powszechna, 2002), 33-36. 
city dwellers from becoming potential testators. Moreover, culturally it is no surprise that the urban poor of the period, who owned little property, rarely made wills: the growing phenomenon of the will was integral to the formation of a burgher culture aspiring to greater rationality, anchored in the ownership of material goods. ${ }^{34}$

\section{$3 \quad$ Municipal Authorities as Testators}

Affluent members of the burgher community with ties to the municipal authorities were the people primarily responsible for the introduction of the practice of making pious bequests for Church institutions and the dissemination of wills as a means of enabling such religious foundations, in the first half of the fourteenth century. Subsequently, in the late-fourteenth and fifteenth centuries, members of this same social group were those most interested in, and prepared for, the disposal of their property and establishment of rules of inheritance that would protect their estate from dispersion. Although the social elite of Krakow was certainly not limited to representatives of the city authorities, it was nevertheless members of councillors' families, endowed with the prestige of a governing authority, who had the greatest influence on the adoption and spread of new cultural trends and legal solutions in Krakow, including the increasing prevalence of the communal will.

Among the 457 Krakow burghers whose wills have survived to this day, 34 were aldermen, and another 71 were councillors. Representatives of the municipal authorities constituted nearly a quarter of all Krakovian testators. If we add to this the eighteen women who appear in wills as the wives and widows of aldermen and councillors, we find that members of these two groups comprise more than a quarter of all known Krakovian testators from the fourteenth and fifteenth centuries. It can be assumed that among those preparing written acts of last will, the final number of people associated with the circles of power, i.e. including all the widows of councillors and aldermen (including those who remarried, and whose new spouses were not city officials) and their children, sons-in-law and daughters-in-law, must have been much higher.

As can be seen from Graph 6, the share of city officials among all known Krakovian testators decreased steadily over the course of the fourteenth and fifteenth centuries. In the first half of the fourteenth century, they constituted

34 "Modern, specifically occidental capitalism grew out of relatively rationally administered, specifically occidental, urban organisations..." Max Weber, Economy and Society, trans. Keith Tribe (Harvard: Harvard University Press, 2019), 373 


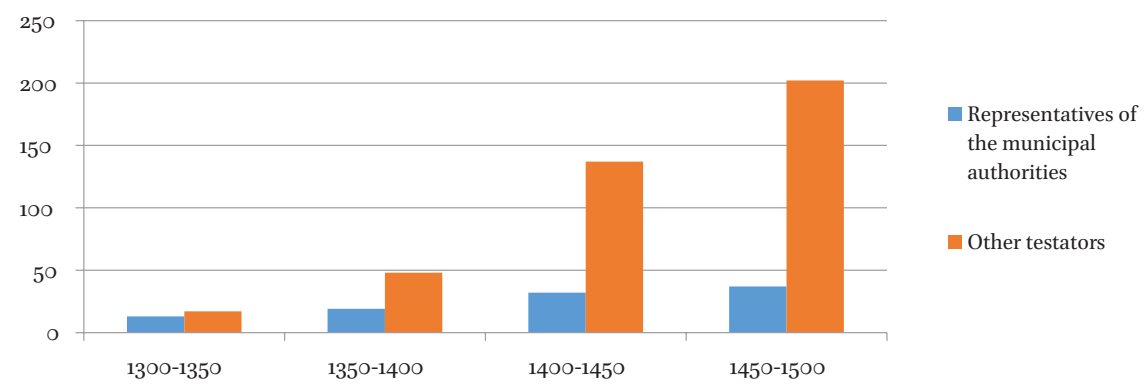

GRAPH 6 Representatives of the municipal authorities among known Krakovian testators in the fourteenth-fifteenth centuries.

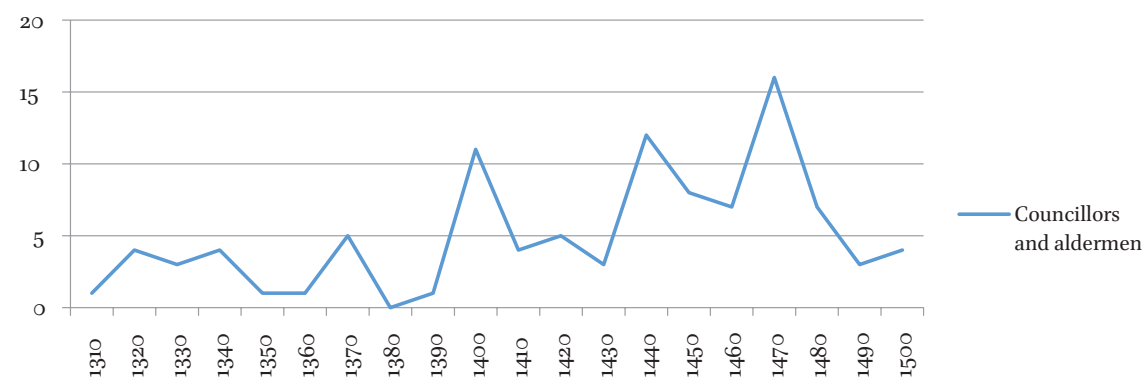

GRAPH 7 Number of councillors and aldermen among known Krakovian testators in particular decades of the fourteenth and fifteenth centuries.

as much as $43 \%$ of all testators, while in the latter half only $28 \%$; in the first half of the fifteenth century, they constituted as much as $19 \%$ of all testators, and in the latter half only $15 \%$.

There are also visible fluctuations in particular decades of the fourteenth and fifteenth centuries in the number of councillors and aldermen whose records of last will have survived to our times (Graph 7). ${ }^{35}$ The most interesting of these are the sharp increases in their number over three decades: 1391 to 1400 (11), 1431 to 1440 (12) and 1461 to 1470 (16).

Although wills are usually more affected by individual, local factors than others, there are some broader social and cultural trends worth considering here. In each of the three 'peak' moments mentioned above, slightly different reasons seem to have prompted members of the elite among Krakow's authorities to write down their last wills. The number of Krakovian wills written during the 1390 (44) that have been preserved is exceptionally large, especially in comparison with previous decades. At that time, the reasons for writing wills,

35 In this study, the date when the will was first written by each person is taken into account. 
and the form they took, changed significantly: the Krakow municipal council assumed a form of patronage over burgher wills, establishing the first book of wills and introducing as a standard practice (German Gewonheit) councillors going to sick burghers to witness the declaration of their last will. Consequently, a new form of communal will was becoming institutionalized. The municipal authorities' new approach to wills and their 'promotion' of the practice of writing an act of last will can be seen in such things as the significant number of wills made by councillors and aldermen during this decade (especially since all of these wills were written by healthy individuals).

The years 1431-1440, when as many as twelve Krakow councillors and aldermen wrote their wills, were also a period from which a significant number of all wills have been preserved. We are probably dealing here with a distortion of research data due to the absence of the first book of wills. It seems possible, therefore, that this steep increase in the number of wills recorded during this period is a reflection of their ceasing to be recorded in the missing first Liber Testamentorum, which likely occurred some time in the 1430s. This hypothesis is supported by the fact that we are not dealing at this time with a specific type of written will, e.g. during an illness or before a pilgrimage, but with various types of bequests of last will recorded both in books of the bench court and in council books.

However, the preservation of as many as sixteen wills made by representatives of the municipal authorities between 1461 and 1470 is mainly due to two important events that took place during this decade. The first was the murder of Andrew Tęczyński in 1461 and the related trial, conviction and execution of three Krakow councillors: Stanisław Leymitter, ${ }^{36}$ Jarosz Szarlej and Konrad Lang, in January $1462 .{ }^{37}$ The second event linked to this increase in the writing of acts of last will was an epidemic of plague in Krakow in 1466 and 1467, when as many as seven councillors and aldermen made such dispositions. ${ }^{38}$

The decrease in the number of wills made by representatives of the ruling elite from the 1470 os onwards is related to a general decrease in the number of wills written in Krakow, due, among other things, to the loss of one or two

36 Sławomira Pańków, "Stanisław Leymitter," in PSB, vol. 17 (Wrocław-Warszawa-Krakow: Polska Akademia Nauk, Polska Akademia Umiejętności, 1971), 263.

37 Stanisław Leymitter, LT, fol. 81; Jarosz Szarlej, LT, fol. 73-74; Konrad Lang, LT, fol. 72-73; Marcin Starzyński, Krakowska rada, 89-96.

38 Bartholomeus Graudencz, sCAB. 8, fol. 246; John Kunisz, scAB. 8, fol. 273; John Czarny, SCAB. 8, fol. 300-301; Jacob Wilkowski, cons. 429, fol. 372; Hartlip Parchwicz, SCAB. 8, fol. 269; Paul Ber, SCAB. 8, fol. 270-271; John Gartner, SСAB. 8, fol. 269. 
books of the bench court from the end of the sixteenth century and a significant decrease in the number of wills entered in council books at that time.

Among the more than 100 wills written by members of Krakow's municipal authorities, the wills of the three above-mentioned Krakow councillors, who were held responsible for the death of Andrew Tęczyński, deserve special attention due to the exceptional circumstances under which they were written. ${ }^{39}$ These men, who were among the most influential citizens of Krakow, were suddenly imprisoned and charged with the capital crime of murder. While awaiting trial in the prison located in the Krakow City Hall, they wrote their wills in accordance with the prevailing practice and notions of a 'good death. ${ }^{40}$

Stanisław Leymitter, the first to write his will, did so before the final verdict was passed on 7 th January 1462 . On July 16th 1461, when the murder of Tęczyński occurred, Leymitter was serving as the city's mayor, which probably assured a guilty plea and left him with no hope of avoiding execution. Compared to other councillors, his situation was made even worse by the fact that he was the homo novus in the group of councillors. Although he had sat on the municipal bench court since as early as 1454, he was not co-opted to the town council until $1461 .{ }^{41}$ The will Leymitter made was traditional in form. ${ }^{42}$ In the first part, he makes bequests to opera pietatis, ${ }^{43}$ to which he allocated 70 florins, and then bequeathed to his wife Sophie 6 oo florins as a dower, secured by his estate. Later in his will, he gave to his brother (perhaps his younger brother) Paul an annual payment of ten grivna "for food and clothing," which he would receive for the rest of his life. At the end of the will, he listed and donated the debts he owed and sums owed to him, along with an inventory of the lead he traded in, to his children - the heirs of the rest of the estate. He confirmed having settled accounts with his brother Nicholas, most likely his business partner, and chose as executors of the will John Wierzynek and his brother-in-law Andrew Czeringer.

39 Marcin Starzyński, Krakowska rada, 89-96; Janusz Kurtyka, Tęczyńscy. Studium z dziejów polskiej elity możnowładczej w średniowieczu (Krakow: Secesja, 1997), 373-374.

40 Stanisław Leymitter did so on January 7,1462 , Konrad Lang and Jarosz Szarlej declared their last wills during the night of January 8; cf. Marcin Starzyński, Krakowska rada, 94.

$41 \quad$ Ibidem, 93, 284.

42 Sławomira Pańków, Stanisław Leymitter, 263.

4320 florins toward the construction of the Church of the Blessed Virgin Mary, 30 florins for the building of St. Bernard's; five florins for food for poor patients of the 'big hospital' of the Holy Spirit; five florins for poor patients of the hospital of St. Hedwig in Stradom; five florins for food for lepers, men and women, both at St. Leonard's and St. Valentine's; LT, fol. 81 . 
Jarosz Szarlej's will is much longer and is rich in interesting information. The career of this renowned councillor (who had held this office since 1455) was likewise interrupted in 1462 by the murder of Andrew Tęczyński. ${ }^{44}$ On the night of the eighth of January, he was detained together with other accused councillors, and wrote down his last will while in prison in the town hall. ${ }^{45}$ The nature of this will is reminiscent of other acts of last will written by people whose illness took them by surprise during the course of their day-to-day lives. In addition to dispositions aimed at safeguarding his family's future, a major part of the will consists of a list of debts and sums owed. Szarlej bequeathed 200 fines to his wife, increased in his will by another 100 fines. He also owned a house at the market square, which his wife had inherited from her father, as well as half of another house at the market square, houses at Slawkowska and St. Florian Streets, and a cloth stall at the market square. The fact that trade in cloth was one of his main income sources is evidenced by the provisions of his will, and in particular by information about a debt owed by King Kazimierz Jagiellończyk of 400 grivna for cloth purchased from the councillor. It is interesting to note that after listing his debtors and creditors, and distributing his movable property, real estate, and clothing and personal items among his children, the testator, who was awaiting his fate on 'death row, decided to make a pious bequest of only a few grivna. ${ }^{46}$

Also interesting is the will of the third convicted councillor - Konrad (Cuncze) Lang, son of the Krakovian alderman and councillor Nicholas Lang ${ }^{47}$ and brother of another Krakovian testator and councillor from Krakow, Stanisław Lang. ${ }^{48}$ Having been raised in a well-rooted Krakovian elite family, Konrad first sat on the municipal bench court from 1442 to 1451, and was then elected councillor, and held this office until $1462 .{ }^{49}$ To his second wife, Hedwig, ${ }^{0}$ he bequeathed 400 florins as a dower, stipulating that every florin should be counted as 28 Czech groschen ${ }^{51}$ He then distributed his movables

\footnotetext{
44 Marcin Starzyński, Krakowska rada, 89-94.

45 LT, fol. 73-74.

46 He bequeathed two grivna to the monastery in Częstochowa, two grivna to the Bernardine monastery in Krakow and ordered 30 Gregorian masses to be celebrated for his soul in the monastery in Mogiła.

47 Marcin Starzyński, Krakowska rada, 93, 278.

48 LT, fol. 117 (1476); Marcin Starzyński, Krakowska rada, 286.

49 Marcin Starzyński, Krakowska rada, 278.

50 She was already married to him in 1451 when she bequeathed her hereditary possessions to him before the municipal council, and in turn, provided for a dower for her in his will before the court; SCAB. 7 , fol. 112, 165, 169 .

“[...] den gulden gerechend umb acht und czwenczig groschen bemische"; LT, fol. 72.
} 
and properties, clearly distinguishing what his wife and children should receive. ${ }^{52}$ In a clear effort to avoid family quarrels and protect his wife from potential disputes with her stepchildren, he guaranteed her the right to live in their house and have one bedroom and one dining room in it (In German eyne kemnot und stube) for as long as she remained a widow. He also divided his property between the children of his first and second marriage and allocated some of his household furnishings (perhaps as a hergewet - the hereditary property due to a man) to his oldest, already independent son, Lawrence. Konrad, like Jarosz Szarlej, owned a company (geselschaft) with his brother Stanisław and entrusted him with the settlement of the money they shared. He also did not leave out his nephew Michael (Michno), to whom he bequeathed a horse, a coat and a robe. ${ }^{53}$ Faced with death, this extremely wealthy testator allotted to pious bequests only a robe, a tunic and a fur, recommending that they be sold and used in dy werk der barmherczikeit, leaving the choice of recipients at the discretion of the executors of the will. ${ }^{54} \mathrm{He}$ ended the will with a listing of his debts and debts owed to him, part of which were to be found in a register he kept, and the names of the executors of the will: his brother Stanisław, his son-in-law Jacob, and Matthias the apothecary. ${ }^{55}$

The wills of the three executed Krakow councillors described above are extremely similar in both form and content to the last wills made by other Krakow burghers. All of them naturally differ in the specifics of the bequests, the family situation of the testators, and the pious bequests made. However, they do not contain anything that would indicate the dramatic situation of the city officials, who were imprisoned and facing death. If the unusual circumstances surrounding the writing of these wills was not already known to us, there would be little cause to focus our attention more closely on them. Knowledge of context such as this, not explained in the testamentary form and not preserved in any other source materials relating to the bequests, undoubtedly provides valuable information indicating how various external circumstances could have impacted the making of final bequests in wills.

\footnotetext{
52 The testator even specified which of the silver cups and spoons should be given to the wife and which to his children; LT, fol. 72 .

"Item so gebe ich Michno meynes bruders son das czelden pfert und den newfarben mantil mit mardern und dy olstene schawbe"; LT, fol. 72.

54 "Item dy marderynne schawbe, und den bruen rog mit mardern und das czobelyn futter, das allis sal man vorkeuffen, und das gelt In dy werk der barmherczikeit gebin noch dirkentnis der vormunden"; ibidem. LT, fol. 73 .
} 
It also seems important that there are no fundamental differences in the content and form of the wills written by city officials and generally unrelated wealthy individuals. However, it can be observed that sitting on a bench court on the municipal council could undoubtedly have had an impact on the need to write a will, as these municipal bodies clearly supported the production of such legal documents.

The source materials on Krakovian testators analysed in this study allow for a determination of the profession of a significant number of these individuals. Their professions can be discerned by a study of the use of nicknames, by information contained in the wills themselves, and by data from various entries in Krakow's municipal books. ${ }^{56}$ On this basis, the professions of 235 testators of both sexes were identified, ${ }^{57}$ which accounts for $51 \%$ of all the burghers whose wills were analysed..$^{58}$ The identified persons represent 53 professions found in greatly varying numbers in medieval Krakow (Table 2). On the one hand, numerically dominant are crafts and trades (35, i.e. 66\%) represented by only one, two or three individual testators during the analysed two hundred years; on the other hand, merchants and stallholders as a group represented as many as 65 testators $(28 \%)$.

In the group of crafts discussed above, the occupational structure is similar to that in other cities in the region. Among Krakovian testators, in Poznan, for example, a decided majority comprises those engaged in the most prestigious crafts. Based on his research on medieval Poznan, Jacek Wiesiołowski placed stallholders and goldsmiths among the wealthiest burghers, alongside

$5^{6} \quad$ Proving particularly useful were annual censuses of guildmasters recorded on the pages of council books. The first, incomplete list of guild masters from 1398 included only the guilds of butchers (arvinatorum), weavers (textorum), cutlers (cultellifabrorum) and belt makers (cingulatorum); CONS. 427 , fol. 103 .

57 Wives and widows of members of these professions were also included in the respective categories.

$5^{8}$ In the course of the study, 457 testators who were Krakow burghers were identified. Among those there were also several foreign merchants who decided to make their wills in the city due to illness or other life-threatening circumstances. However, 11 people were excluded, since their short mutual bequests or donations, made e.g. due to travel plans or plague, could also serve as a last will; these were significantly different in form from other wills. There were also 10 excluded wills of clergymen who left their wills in town books through their roots, connections and family ties. 
TABLE 2 Occupations of Krakovian testators in the years 1300-1500

Occupation

Number of

testators

Merchants and stallholders (mercator, kaufman, institor, kromer) 64

$\begin{array}{ll}\text { Goldsmiths (aurifaber, goltsmed) } & 14\end{array}$

Belt makers (cingulator, gortler) 10

$\begin{array}{lr}\text { Sellers of fustian fabric (parchanista, parchener) } & 9\end{array}$

$\begin{array}{lr}\text { Innkeepers (tabernator, kreczmer) } & 9\end{array}$

Brewers and maltsters (braxator, braseator, melczer) 8

Butchers (carnifex, fleischer) $\quad 8$

$\begin{array}{ll}\text { Tailors (sartor, schneider) } & 7\end{array}$

$\begin{array}{ll}\text { Shoemakers (sutor, schuster) } & 7\end{array}$

Bowyers (crossbow makers) (arcufex, bogner) 6

$\begin{array}{ll}\text { Bakers (pistor, becke) } & 6\end{array}$

Armourers and bladesmiths (torrifex, helmsmed, plathnerz) 5

Fish sellers (allecista, heringer, senior in foro piscium) 5

Capmakers (pileator, hutter) 4

Furriers (pellifex, korsner) 4

Sausage Makers' (arvinator, smersneyder) 4

Scribes and notaries (notarius, schreiber) 4

Salt merchants (salicida) $\quad 4$

Coopers (doleator, botener) 3

Pewter makers and bell-founders (cantrifex, kannengisser, cuprifaber, 3

ruffifusor, rothgisser, pixidarius)

Blacksmiths (faber, parvifaber, smed)

Bathhouse owners (balneator, bader) 3

Cutlers (cultellifaber, messirsmed) 3

Leatherworker (corrigiator, rymer) 3

Servants (servitor, vigil, dyner, circulator) 3

Tanners (cerdo, gerber, rufficerdo, rotgeber) 3

Apothecaries (apothecarius, apteker) 2

Professional court deputies (prolocutor, vorreder, vorsprecher) 2

Embroiderers (haftarius, zaidenhafter, hafter) 2

Purse makers (bursifex, perator, beutler) 2

Painters (pictor, moler) 2

Minters (monetarius, monczer) 2 
TABLE 2 Occupations of Krakovian testators in the years 1300-1500 (cont.)

Occupation

Number of

testators

Soap makers (smigmator)

Carriage-builders (currifex, stelmecher)

Weavers (textor, weber)

Salt mines administrators (supparius)

Customs officials (teloneator)

Dyers (tinctor, farber)

Potters (figulus, topper)

Barbers (barbitonsor, barbirer)

Needle makers (acufex, noldener)

Equerries (marstelle)

Sword makers (gladiator, zarwechter) 1

Millers (molendinator, molner) 1

Bricklayers (murator, mewrer) 1

Oil makers (oleator, olslager) 1

Silver malters (cremator) 1

Glovers (cirothecarius) 1

Saddlers (sellator, zatheler) 1

Joiners (mensifex, teschner) 1

Glaziers (vitreator, glezer) 1

Candle makers (luminator, sweszniczka) 1

Coat makers (menteler) 1

furriers, brewers, doctors, butchers and tailors. ${ }^{59} \mathrm{~A}$ similar hierarchy among professions can be found in Wrocław, where at the turn of the fourteenth and fifteenth centuries innkeepers and some stallholders were among the richest burghers, and rich in comparison to many craftsmen - such as butchers, bakers, shoemakers, weavers, maltsters, goldsmiths and furriers. At the same time, a profession's prestige was also influenced by the strength of its guild. ${ }^{60}$

59 Jacek Wiesiołowski, Socjotopografia, 30-53.

6o "This is no coincidence, but rather a source of their strength. Apart from prestige and wealth, the evaluation of the profession was based on 'political' factors, the position in the commune expressed in terms of numbers and its economic importance"; Mateusz. Goliński, Socjotopografia, 462-463. 
In German cities, such as Brunswick, Wartburg, Goslar and Göttingen, cloth cutters, weavers, tanners, shoemakers, goldsmiths, bakers and stallholders were among the most important groups of burghers. ${ }^{61}$ Studies on the social structure of medieval Torun carried out by Tomasz Jasiński and Krzysztof Mikulski indicated similarities with the occupational hierarchy presented above. At the turn of the fourteenth and fifteenth centuries in Torun, brewers, saddlers, goldsmiths and wheelwrights were among those practicing the most highly valued crafts. ${ }^{62}$

\subsection{Merchants and Stallholders}

Analysis of the data presented in Table 2 above leads to interesting conclusions concerning the prevalence of the institution of the will among particular professional groups. The most common occupational group among testators was undoubtedly merchants. Because of the blurred and rather arbitrary boundary between merchants and stallholders, the two activities were treated together in this research. Some testators involved in trade were poor stallholders, such as Peter Chromy, ${ }^{63}$ or from the middle-class, such as Stanisław Kulek, ${ }^{64}$ but the vast majority were wealthy or very wealthy members of the upper social strata of Krakovian burghers. Among the testators on a list from 1410 were both elders of merchant guilds (in Latin seniores mercatorum), ${ }^{65}$ the aldermen and, later, councillors like Nicholas Glezer, ${ }^{66}$ and Paul Homan, ${ }^{67}$ as well as many others who served as elders of the stallholders guild (seniores institorum), such as councillors Peter Hirszberg, John Weinke and Stanisław Streicher, and alderman Matthias Opoczko. This group also includes foreign merchants, such as John Raisser from Memmingen, Wilhelm Megirszheimer from Bavarian

$61 \quad$ Dietrich Denecke, Sozialtopographie und sozialräumliche Gliederung der spätmittelalterlichen Stadt, in Über Bürger, Stadt und städtische Literatur im Spätmittelalter, ed. Josef Fleckenstein, Karl Stackmann (Göttingen: Vandenhoeck \& Ruprecht, 1980), 180-183.

62 After a period of economic crisis resulting from the Thirteen Years' War, in the latter half of the fifteenth century there was a sudden change in the direction and logistics of how trade was done, which also affected the property structure of Torun's craftsmen. At that time, bakers, brewers and representatives of leather crafts (mainly furriers) gained importance and wealth; vol. Jasiński, "Z zagadnień topografii społecznej średniowiecznego Torunia, part 1: Stare Miasto," 'Zapiski Historyczne' 48, no. 3 (1983), 132-133; Krzysztof Mikulski, Przestrzeń i spoteczeństwo Torunia od końca XIV do początku XVIII wieku (Toruń: Wydaw. Uniwersytetu Mikołaja Kopernika, 1999), 133.

63 CONs. 429, fol. 16-17 (1450).

64 LT, fol. 93 (1468).

65 CONS. 427 , fol. 361,377 (1410).

66 SCAB. 4, fol. 66b (1412); SCAB. 5, fol. 121 (1426).

67 SCAB. 5 , fol. 79 (1423). 
Dinkelsbühl (Thunkilspul, near Nuremberg) as well as Erhart Eigilwart from Augsburg, who settled in Krakow. ${ }^{68}$ Also qualifying as stallholders were many burghers who bequeathed stalls in their will, as well as their wives and their widows, such as Catherine, wife of the senior stallholder Peter Bedlka, who in her will mentioned two stalls she owned in the city; ${ }^{69}$ Łazaria, the rich owner of a cloth stall and wife of Nicholas Slop; ${ }^{70}$ and the first testator in Krakow (whose will has survived to our times) Sulisława, who had a stall, a butcher's stall, and a bread stall. ${ }^{71}$ Although it is unlikely that all of these individuals were personally involved in trading from these stalls, which were sometimes owned by them only as a form of capital investment, it seems that the business activity of renters - consisting of carrying out investments, obtaining loans and the renting itself - was much closer to the types of work performed by a merchant and stallholder than to those of a craftsman.

The number of people among Krakovian testators who profited from commercial and credit transactions was in fact much higher than the number of actual stallholders recorded, perhaps even twice as high, given that most members of Krakow's elite had multiple sources of income and some craftsmen also traded in real estate, made loans, and set up their own trading companies. It can also be assumed that for a significant portion of Krakow's wealthy citizens who were outside circles of power, regardless of their designated profession, trading activities comprised at least one of a number of sources of income. A good example of such professional mobility is Simon the needle-maker (in German noldener), whose profession and limited participation in the city's official public life indicate that he most likely did not possess much property. Simon held the position of an elder of the blacksmiths guild in 1463, near the end of his life. ${ }^{72}$ There are few mentions of him apart from information that in 1448 he bought a house at Szczepańska Street worth 15 o grivna from the executors of Peter Eichler's will. ${ }^{73}$ If he had not left three versions of his will, ${ }^{74}$ it would have been difficult to believe that he was one of Krakow's richest burghers, who, alongside his work as a craftsman, was also engaged in trading and lending activities.

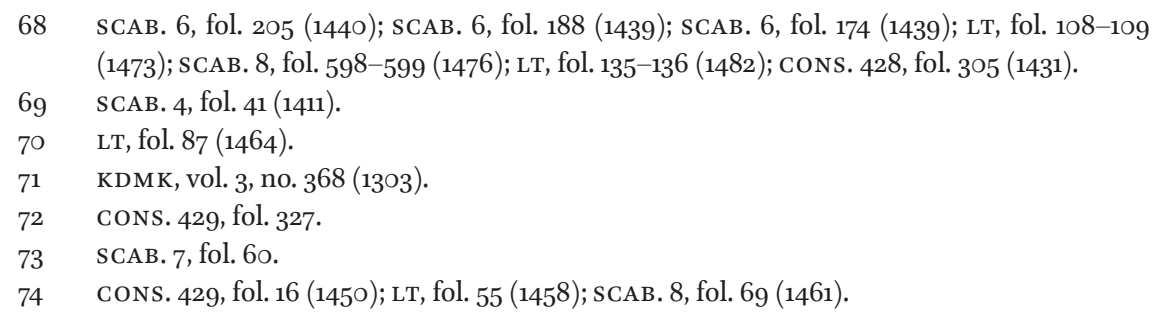


Simon made his first bequest of last will in the Jubilee year of $145^{\circ}$. Before making a pilgrimage, he made a simple bequest of all his possessions to his two daughters and wife Dorothy. He named Sigismund the butcher and Paul Brower the furrier as the executors of the will. ${ }^{75}$ Eight years later, he made another will before councillors who came to him to witness the document, in which he bequeathed everything to his second wife Catherine, including 100 florins as her previously promised dower. ${ }^{76} \mathrm{He}$ also gave 300 florins for pious deeds, of which 200 were to be donated to St. Bernard's Church. ${ }^{77}$ This time the executors of the will were the future alderman and councillor Nicholas Gobil and two elders of the blacksmiths guild, Stanisław Schilling and Nicholas Wogisgeringe. Three years later Simon made his third will, this time before a municipal bench court. ${ }^{78} \mathrm{He}$ once again bequeathed to his wife Catherine a dower of 100 florins as well as the contents of a stall (in German cromgerethe, but not the craft tools - werkgeczew), as well as valuable items and household equipment pledged to him. ${ }^{79}$ This time he confined himself to bequeathing nearly 100 florins for pious deeds, ${ }^{80}$ but in this version of his will he included additional relatives, who were to receive 20 florins "if they arrived within a year and a day." As executors of the will, he again chose the same two elders of the blacksmiths guild, Schilling and Wogisgeringe, to whom he allocated two florins each for carrying out the aforementioned dispositions.

$75 \quad$ CONS. 429 , fol. 16.

76 LT, fol. 55 .

77 "10 florins to the Blessed Virgin Mary Church for the construction of the church; two grivna to the Hungarian Chapel of St. Francis for the brotherhood; two grivna to the main hospital for the poor for food; 10 florins to St. Hedwig for the sick; 10 florins to All Saints for construction; 10 florins to St. Francis for construction; 12 florins to St. Valentine for food for the sick; 10 florins to St. Leonard for food for lepers; 20 florins to Corpus Christi in Kazimierz for construction; four grivna to St. Stephen for construction; 10 florins to St. Mark for construction"; CONS. 429, fol. 16.

78 SCAB. 8, fol. 69 (1461).

79 Among the items pledged with him he mentioned a gold-plated belt, two gold rings worth altogether 12 florins, 12 silver spoons pledged for eight florins and a chalice from the socalled Hungarian chapel [!] pledged for six grivna.

8o "10 florins to the Blessed Virgin Mary for construction; 10 florins to the Hospital of the Holy Spirit for food for poor patients; 20 florins to the brotherhood of St. Bernard for their needs; and another 20 florins to build their monastery; 10 florins to St. Francis for construction of the monastery; and I give 20 florins to my relatives who will come within a period of a year and a day, in accordance with the law of next of kin. If none of the relatives comes during this time, the 20 florins will be added to the sum for construction of the Blessed Virgin Mary Church; 10 florins for czu wegin und czu stegin; two grivna to St. Valentine; two grivna to leprous women; two grivna to leprous men at St. Leonard"; scAB. 8 , fol. 69 . 
Apart from burghers, who can generally be described as merchants and stallholders, the table above also includes people trading in specific types of goods, such as sellers of fabrics (fustian), among whom were nine guild elders, including two councillors John Sweidniczer ${ }^{81}$ (one of the richest burghers in Krakow) and John Beme, ${ }^{82}$ and an influential cloth and silk merchant Nicholas Dolsky (alias Swob); ${ }^{83}$ five fishmongers, among whom three were distinguished as 'elders of fish market' (seniores in foro piscium); ${ }^{84}$ four salt merchants (Polish prasot), whose considerable wealth can be inferred, for example in the cases of John Włosaty and Michael Godzek, ${ }^{85}$ on the basis of the high fees paid by them during the adoption of municipal law. ${ }^{86}$ Taking into account these groups of occupations as well, the number of merchants and stallholders identified among testators can be estimated to be no less than 84 persons (36\%).

One example of a wealthy Krakow fishmonger is John Czarny, who served as the senior in foro piscium from 1459 to $1465 .{ }^{87}$ Later in his career, in $1466,{ }^{88}$ he was nominated as a alderman and served in this function from 1467 to $1474 .{ }^{89}$ His appointment as commander of the tower over the New Gate (Latin Novam Valvam) in 1473 can be seen as an expression of his social prestige. ${ }^{90}$ In 1465 , in a will made before the municipal bench court, he bequeathed the significant sum of 100 grivna to his wife. ${ }^{91} \mathrm{He}$ also sought to secure the future of his wife after his death, requiring his children to give her a sunny room and a free table at which she could sit in the dining room under the window by the heater. In

81 The example of John Sweidniczer clearly shows just how misleading the simple classifications of the professional activities of burghers based on their nicknames or their guild functions were. His will of 1457 alone provides evidence of the great variety of financial and trade activities undertaken by this wealthy townsman. His most important sources of income included international trade in lead, cloth, iron, copper, wine and salt; cf. cons. 428, fol. 402 (1439); LT, fol. 39-45 (1457); senior parchanorum, 1438, cons. 428, fol. 384; cf. Danuta Molenda, Polski otów na rynkach Europy Środkowej w XIII-XVII wieku (Warszawa: Instytut Archeologii i Etnologii PAN, 2001), 104-106.

82 LT, fol. 86-87 (1465); senior parchanorum, 1436, 1439, 1443, CONs. 428, fol. 352, 399, 456 .

83 LT, fol. 143-144 (1487); senior parchanorum, 1468, 1472, 1475, 1478, 1480, CONS. 429, fol. 404, $463,527,606,653$.

84 Martinus Weyner, LT, fol. 68-69 (1461); Czarny John, sCAB. 8, fol. 223 (1465); Duchon, CONs. 429, fol. 382 (1466).

85 They both wrote their wills in 1494; LT, fol. 154.

86 They paid 36 and 24 groszy, respectively; cf. Book of Admissions, no. 8747, 347 i no. 6399, 213.

87 CONs. 429 , fol. 227,359 .

88 SСAB. 8 , fol. 262.

89 SCAB. 8, fol. 371, 473, 482, 483, 501-502, 5 O9.

90 CONS. 429 , fol. 485 .

91 She was supposed to be paid these 100 grivna by the children of the testator (probably from his first marriage), and until they did, they should pay her rent out of that amount; CONS. 429, fol. 227, 359 . 
addition, the children were to meet all her other needs. ${ }^{92}$ Later on in the will he gave his two sons Adam and Pawel 100 florins each, then divided the rest of the estate in equal parts among all his children, explaining that his daughters Hedwig and Barbara had already left the house, and had already received a similar amount of money as a dowry. Most of these dispositions were repeated by the testator in the second version of his will, which he had drawn up while serving as a alderman. ${ }^{93}$ In this version, however, he left his entire house, located behind his butcher's stall, to his wife for life, as well as repeating his earlier bequest of 100 grivna to her as a dower. Interestingly, in 1475 the sons of John Czarny, Adam and Paul, made a mutual bequest of all their possessions, claiming that they had earned everything they had from their own work and not inherited anything, and therefore could exclude their relatives from any inheritance. This decision was confirmed in court by their father, who added that he owed them 100 florins for cloth. ${ }^{94}$ Information about John's death and the execution of his testamentary dispositions is found in the record for the following year $-1476 .{ }^{95}$

\subsection{Goldsmiths and Belt Makers}

The second and third group of professions most commonly found among testators (24 persons $-10 \%)$ are the closely-related professions of goldsmith and belt maker (belts were very often decorated with silver ornamentation and sometimes even gold plated). These guilds represented the richest and most prestigious group of Krakovian craftsmen. A certain affinity and mutual ties between the representatives of these trades can be seen in the example of the Pferd family, in which there were two members named John. One of them was a goldsmith, and the other, a belt maker from Zittau. ${ }^{96}$ It is not known exactly how the two were related, but it is notable that Agnes Pferdinne, who originally came from this family, was the wife of a belt maker named Nicholas, who had the nickname Goldener ${ }^{97} \mathrm{He}$ also made his will shortly after Agnes's death, after entering into a new marriage with 'Magdalene. 98

\footnotetext{
92 If the testator's children wished to sell the house, they could only do so if they granted the widow the conditions specified in the will ("dassy den freyen willen und dy gebunge dy ich ir benumit habe yn meynem hawse sal sy haben und genissen als oben und sust sal das haws nicht vorkowft warden"); cons. 429, fol. 227, 359 . 
Although he was never a member of the city council or bench court, the goldsmith John Pferd was a very influential burgher, as evidenced by the fact that his wife Margaret was the daughter of the alderman and Krakow councillor Peter Pelczer the furrier. ${ }^{99}$ In the town books, one can find information about the professional and social career of this testator, who in 1422, 1427, 1431, 1434 and 1439 served as an elder in the goldsmiths guild, ${ }^{100}$ and in 1430 was elected as a defense commander of the Jewish Tower (in Latin capitanus Turri Judeorum ). ${ }^{101}$ John Pferd left behind an exceptionally large number of surviving wills (as many as five, from 1423, 1425, 1439, 1445 and $1445^{102}$, which provide us with a relatively good knowledge of his property and family status. He drew up the first of these acts of last will in 1423 before leaving on a pilgrimage to Rome. In it he bequeathed to his wife Margaret 200 grivna, while another 100 grivna and the tools of his craft were to be divided up between his mother Catherine and the offspring of his siblings (he mentions his nieces and nephews). ${ }^{103}$ Two years later, after returning from his pilgrimage and (probably) after his mother's death, he made another will in which he bequeathed a total of 120 grivna to more distant family members such as his cousin Sophie, from the Upper Silesian town of Niemodlin (in German Falkenberg). ${ }^{104}$ In 1439, in the third version of his will, he confined himself to securing a dower for his wife and making provisions for his sister, adult niece, two underage nieces and maid, allocating 15 o florins for this purpose, and the rest to opera pietatis. ${ }^{105}$ When, six years later in 1445 , he made another version of his will, it no longer mainly featured bequests to his family, but detailly planned pious bequests, for which he allocated 138 florins. From among the members of his large family, he now included only his sister from Niemodlin, to whom he bequeathed 50 florins, and his wife, who became the beneficiary of most of the estate, and whose dower of 200 grivna was increased by another 100 grivna; she also received a house at the market square and all its furnishings. ${ }^{106}$ In the same year, the testator changed his will once again, probably out of fear that his relatives might challenge the will in court. This will, made before the municipal bench court, was more of a mutual bequest, in which the testator bequeathed to his

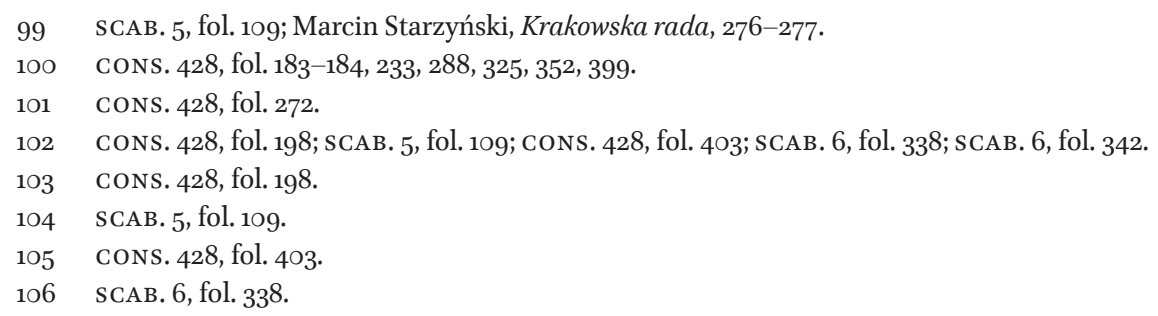


wife a larger dower and secured it with his home on the market square; she, in turn, left him the same property along with her dowry in the event that she died first. They both disinherited their relatives from their common property. ${ }^{107}$ The wills left by John Pferd show both the growing wealth of the burghers and the gradually decreasing share allocated to relatives in their inheritances. His initial, large estate was enlarged thanks to his marriage to the daughter of the wealthy future councillor Peter Pelczer. His business and family connections allowed him later to buy a house on the market square, and to enlarge it in $1431 .^{108}$ This was a visible trace of his social position. ${ }^{109}$

\subsection{Food-Related Crafts}

Those engaged in food-related crafts among Krakovian testators included those involved in the production and sale of beer (brewers, maltsters and innkeepers) as well as bakers and butchers (in total 35 people $-15 \%$ ). For the most part, they were middle-class and wealthy burghers, though none of them were aldermen or councillors. The professional activities of the owners of butcheries and malt-houses, who sold their products in Krakow's taverns and markets, shared features with those performed by both stallholders and craftsmen, who sold the goods they produced. Butchers were often the most rebellious social group in medieval towns, perhaps because of their borderline position between merchants and craftsmen. Hanna Zaremska, in her description of the relations between religious fraternities and urban elites, noted:

Cooperation between brewers and butchers was an expression of an alliance among a group of rich people who did not differ in material terms from the merchant families who ruled the city. Conflicts caused by their exclusion from the ruling class led these craftsmen to launch armed protests against the authorities, and in times of 'social tranquility' to seek other ways to satisfy their ambitions. ${ }^{110}$

107 SCAB. 6 , fol. 342.

108 That year he bought a half of a house at the market square from Anna, wife of Stanisław Morsztyn, which was located next to his own property at the market square.; SCAB. 6, fol. 18 .

109 Cf. Jerzy Pietrusiński, Ztotnicy krakowscy, 387-39o.

110 They were initiators or participants in the majority of revolts against the municipal authorities and merchants supporting them, e.g. in Wrocław in 1408, Gdańsk, Toruń and Poznan;Janusz Tandecki, Struktury administracyjne i spoteczne oraz formy życia w wielkich miastach Prus Krzyżackich i Królewskich w średniowieczu i na progu czasów nowożytnych (Toruń: Uniwersytet Mikołaja Kopernika, 2001), 82-88; Edmund Cieślak, Walki ustrojowe w Gdańsku i Toruniu oraz niektórych miastach hanzeatyckich w XVw. (Gdańsk: Gdańskie 
An example of a - not particularly wealthy - representative of the foodrelated crafts was Martin Masarz. In 1415, he bequeathed before the municipal bench court all of his movable and immovable property to his wife Catherine and son John Schirmer, except for his "butcher's shop" (thugurium arminale vulgariter Smerhutte), which was to be run by Catherine as long as she remained a widow, and then reserved for Martin's grandson. ${ }^{111}$ In 1419, "lying in sickness," Martin revoked before councillors all his previous bequests and donations, leaving to his son John all his movable and immovable property, except for 10 grivna, which he intended as - an unusually small - dower for his wife. The value of the total Martin's real estate is not known, but the dower bequest indicates that the economic position of this testator could not have been too high. However, we can speak of a social advancement in the case of his son John, who in 1416 and then in 1421 held the position of elder in the butcher's guild. ${ }^{112}$

\subsection{Clothing-Related Crafts}

Among the crafts represented by a relatively large number of Krakovian testators were the traditionally rich guilds of tailors and furriers and of capmakers (a total of 15 people $-6 \%$ ). The majority of tailors occupied a high social position. The richest of them appears to have been Peter of Pyzdry, called as a "tailor to the Queen," and later a councillor and court vogt. ${ }^{113}$ Apart from the valuable real estate he owned, further proof of his importance in the city was the fact that his son-in-law was Jacob Sweidniczer, brother of John Sweidniczer, one of the most influential patricians in Krakow. Peter earlier bequeathed to his wife a dower of 250 grivna, then increased it in his will to an impressive 700 grivna. In addition, there are wills of other wealthy townspeople who were engaged in tailoring crafts, such as the councillors John Teschner, Jarosz Clothier and John Biały. ${ }^{114}$ Estates only slightly smaller were most likely owned by the tailor John Tifnaw, who concluded a form of marriage contract (gemechte) with his wife in $1441,{ }^{115}$ and Elizabeth, the widow of the deceased tailor Philip, who owned a house on Pig Street. ${ }^{116}$

\footnotetext{
Towarz. Nauk, 1960), 20-21; Antoni Gąsiorowski, "Walki o władzę w Poznaniu u schyłku wieków średnich," KH, vol. 82, no. 2 (1975), 256-259; Hanna Zaremska, Bractwa, 105.

The value of this butcher's shop is difficult to estimate, but the mere fact of its possession indicates the relatively stable financial and professional position of this burgher; cons. 427 , fol. 88,159 .

LT, fol. 4 (1442); Marcin Starzyński, Krakowska rada, 274-275. SCAB. 8, fol. 577 (1475), LT, fol. 151-152 (1492), LT, fol. 133-134 (1482).

Together they bequeathed as many as 100 grivna (50 each) for the salvation of their souls. Furthermore, after John's death, his widow was supposed to receive 50 grivna from her father's inheritance and 40 grivna from the dower she was entitled to; SCAB. 6, fol. 227 . CONS. 429, fol. 55 (1452); SCAB. 7 , fol. 312 (1457).
} 
Four identified furriers were undoubtedly part of Krakow's elites. Matthias Paszke was an elder of the furriers guild in the years 1436, 1438, 1447, 1453, 1455 and $1457,{ }^{117}$ and in 1460 he was elected as a senior stallholder. ${ }^{118}$ In addition, from 1440 to 1469 , he sat on the bench court at least thirteen times, and in 1469 was elected for the first time to the municipal council, on which he also appears in the censuses of 1476 and $1477 \cdot{ }^{119} \mathrm{John}$ Kunisz ${ }^{120}$ and Michael Graser, ${ }^{121}$ before they were elected to the municipal bench court, held the office of elders of the furriers guild for many years, while John Baumgart's position as head of this guild is evidenced by his house on the market square and his kinship ties with the Morsztyn family. ${ }^{122}$

Two masters of the capmakers guild, Nicholas Tunkel and Matthias Hutter, and two widows of former guild elders, Hedwig Granoszowa and Anna Mazerinne, were part of much less wealthy circles among Krakovian burghers. ${ }^{123}$ They owned properties located on the side streets of Krakow, ${ }^{124}$ and their bequests were clearly different in size from those of the above-mentioned tailors and furriers.

\subsection{Metalworking and Armour-Making Crafts ${ }^{125}$}

Surprisingly, there is also a large representation of crafts related to the production of weaponry, such as bowyers (crossbow-makers), ${ }^{126}$ armourers, bladesmiths and at least one gunsmith (Latin pixidarius) belonging to the

117 Senior pellificum, 1436 , cons. 428 , fol. 352 ; 1438 , coNs. 428 , fol. 384 ; 1447 , CONS. 428 , fol. 497; 1452, CONS. 429, fol. 44; 1455, CONS. 429, fol. 114; 1459, CONS. 429, fol. 227.

118 CONS. 429, fol. 265 .

119 LT, fol. 108 (1473); Marcin Starzyński, Krakowska rada, 289.

120 SCAB. 8, fol. 273 (1467); LT, fol. 126 (1481).

121 LT, fol. 34 (1455).

122 SCAB. 6, fol. 215 (1440); CONS. 428, fol. 466 (1443).

123 SCAB. 6, fol. 149 (1437), SCAB. 7, fol. 13 (1447); SCAB. 5, fol. 157b (1428); SCAB. 6, fol. 168 (1438); LT, fol. 5 (1440); LT, fol. 145 (1487); LT, fol. 3 O (1453).

124 Matthias Hutter had a house on St. Florian Street, and Hedwig Granoszowa owned one on twergasse next to the house of the poor (bursa pauperorum); Anna Mazerinne, widow of John Mazer, had a house on Wiślna Street next to the gate; SCAB. 5 , fol. 157b (1428); SCAB. 6, fol. 168 (1438); LT, fol. 5 (1440); LT, fol. 135 (1487); SCAB. 6, fol. 335 (1445).

125 Division adopted from: Janusz Sztetyłło, "Rzemiosła metalowe wraz z uzbrojeniem," in Historia kultury materialnej Polski w zarysie, vol. 2: Od XIII do XV w., ed. Anna RutkowskaPłachcińska (Wrocław-Warszawa-Krakow: Zakład Narodowy im. Ossolińskich, 1978), 73-108.

126 Jan Szymczak, "Od samostrzelników do grzebieniarzy w Krakowie, czyli rzecz o zmierzchu znaczenia kuszy na przełomie XV i XVI wieku," in Aetas media, aetas moderna. Studia ofiarowane profesorowi Henrykowi Samsonowiczowi w siedemdziesiata rocznicę urodzin, ed. Agnieszka Bartoszewicz, Wojciech Fałkowski, Halina Manikowska, Antoni Mączak, Karol Modzelewski (Warszawa: Instytut Historyczny Uniwersytetu Warszawskiego, 2000), 122-128. 
bell-founders guild (a total of thirteen people $-5.5 \%$ ). We can speak of an extreme affluence in the case of the aforementioned bladesmith Thomas Zarwechter, who served as a guild elder and then became an alderman (in 1448 and again in 1450), ${ }^{127}$ after which he was quickly promoted to the office of Krakow councillor (1452-1466). ${ }^{128}$ Perhaps the secret of his quick social advancement, quite unusual for his profession, is connected with his marriage to the rich widow of Mark the innkeeper in $1440 .{ }^{129}$

Although craftsmen from the tinsmiths and bell-founders guilds are not primarily associated with the production of weapons, John Stochse, a gunsmith whose nickname indicates his specialisation in the production of firearms, was a member of precisely this guild. The four versions of his will allow us to examine closely his property and family status. ${ }^{130} \mathrm{He}$ served, with some interruptions, for many years - from 1415 to 1459 - as an elder in the guild of tinsmiths and bell-founders. ${ }^{131}$ Although he owned only a wooden house on Hospital Street, his significant wealth is indicated by his generous bequest for his wife's dower, which he increased to 140 grivna, and the fact that in his will we find a clear symbol of wealth and social prestige - a precious gold-plated belt. ${ }^{132}$

We can speak of moderate wealth in the case of most of those among the four armourers and five bowyers among the Krakovian testators. Besides Jacub Rolle and his wife Claire, who stood out in this respect, ${ }^{133}$ the other persons were middle-class members of the urban community. For example, Jost the bowyer (in German bogner) made a bequest for his wife's dower of 30 grivna and Henczil the bowyer (in Latin arcufex) 50 grivna, while everyone associated with Krakow's armourers guild - Nicholas Fridil the armourer (in German plathner), ${ }^{134}$ Wojtek the armourer, ${ }^{135}$ Catherine wife of Fricz the armourer ${ }^{136}$

Senior gladiatorum, 1433 , CONS. 428, fol. 315 .

128 Marcin Starzyński, Krakowska rada, 278.

129 CONS. 428, fol. 412 (1439); SCAB. 6, fol. 209 (1440).

130 CONS. 428, fol. 317 (1433); LT, fol. 30 (1453); LT, fol. 33 (1454); LT, fol. 51 (1458).

131 For example, in 1437 he belonged to the guild: Cuprifusorum, cantrifusorum et messingsloer, but in 1447 Cantrificum Rufifusorum and in 1454 Cantrificum Ruffifusorum; cons. 428, fol. 370 (1437); CONS. 428, fol. 497 (1447); CONS. 429, fol. 84 (1454). CONS. 428, fol. 317 (1433); LT, fol. 30 (1453); LT, fol. 33 (1454); LT, fol. 51 (1458).

He bequeathed as many as 160 grivna as a dower for his wife, and after his death the widow, Claire gave the house 'behind the slaughterhouses' to found a perpetual mass at St. Mary's Church, and also made pious bequests worth more than 100 grivna; SCAB., no. 1425 (1392); KDMK, vol. 3, no. 406, 532-534 (1419); SCAB. 5, fol. 31 (1420). CONS. 428 , fol. 317 (1433).

135 LT, fol. 143 (1487).

136 SCAB. 6, fol. 74 (1434); SCAB. 6, fol. 361 (1446).
} 
and Anna wife of the helmet maker ( in German helmsmedinne) ${ }^{137}$ - were all owners of wooden houses on the prestigious Grodzka Street.

\subsection{Professionals of the Written Word}

Among Krakovian testators, professions requiring a formal education are relatively well represented (eight persons $-3 \%$ ). ${ }^{138}$ These include the wills of three municipal notaries: John Stolle, ${ }^{139}$ Eustace and Christopher Rebentcz, ${ }^{140}$ as well as the public notary and later councillor Nicholas Zarogowski, ${ }^{141}$ the municipal deputy notary (in German undirstatschreiber) Nicholas Newmaister, ${ }^{142}$ two professional court plenipotentiaries Peter Streicher and Lawrence ${ }^{143}$ and, to a lesser extent, the pharmacist Paul Tanneman and Dorothy, widow of the

137 SCAB., 1641 i 1642 (1393).

138 "Apart from the notary employed in the municipal office, there were also other professional writers who could edit a document or letter, read and translate more or less complicated texts, and explain the complexities of law"; Agnieszka Bartoszewicz, Piśmienność (2012), 193 .

139 KDMK, vol. 3, no. 406, 532-534 (1419 r.); SCAB. 6, fol. 186 (1439); LT, fol. 61-63 (1459); CONS. 429, fol. 693 (1481); Bożena Wyrozumska, Kancelaria miasta Krakowa $w$ średniowieczu, 121-124; Agnieszka Bartoszewicz, Piśmienność (2012), 163-165.

140 'People in 'intellectual professions' were an important, perhaps even the most important group from the point of view of research on urban literacy: notaries employed in offices and courts, as well as by private individuals, then book copyists, tutors, court attorneys, and finally - doctors and pharmacists who required professional knowledge in their work. [...] All these people had one thing in common - they made money using a pen and were engaged in one or more of the above-mentioned professions. On the other hand, they differed in terms of wealth, social prestige, level of education and social rank"; Agnieszka Bartoszewicz, Piśmienność (2012), 36-37.

141 CONS. 429, fol. 15-16 (1450); LT, fol. 129-131 (1482); The fact that Nicholas Zarogowski held the position of public notary was mentioned in Elżbieta Piwowarczyk, Legaty testamentowe ad pias causas, $5^{\mathrm{O} 2}$. A version of his last will and testament from 1472 is kept in the archives of Jagiellonian University; cf. Codex diplomaticus Universitatis Studii Generalis Cracoviensis, vol. 2, ed. Feliks Piekosiński (Krakow: sumptibus Universitatis, 1870-1880), no. 236 .

142 Although in the Old Polish period there were such terms as podpisek and pisarczyk junior writer, such a translation of the term undirstatschreiber in the medieval period would mean a major departure from the source terminology; cf. Krzysztof Skupieński, "Notariusze i notariat w średniowiecznej Polsce," in Kultura piśmienna średniowiecza i czasów nowożytnych. Problemy i konteksty badawcze, ed. Piotr Dymmel, Barbara Trelińska (Res Historica, 3), (Lublin: Wydawn. Uniwersytetu Marii Curie-Skłodowskiej, 1998), 169-170; SCAB. 7 , fol. 120 (1451).

CONS. 428, fol. 125 (1419); SCAB. 6, fol. 184 (1439). 
pharmacist Stanisław. ${ }^{144}$ All the municipal notaries who made wills had significant assets at their disposal, numbering in the hundreds of grivna. ${ }^{145}$ The Krakow's deputy notary Nicholas and his wife Salomea made a mutual bequest that for the 300 grivna he had received from her as a dowry, he would leave her half of his entire estate, which therefore had to be worth at least 6oo grivna. ${ }^{146}$ The pharmacist Paul Tanneman also had a very large estate, ${ }^{147}$ and also owned a house on the market square. ${ }^{148}$ The situation of two professional court plenipotentiaries from Krakow, however, was more complex. As A. Bartoszewicz explains:

The entries in the municipal books of seemingly all urban centers prove the popularity of the institution of the legal plenipotentiary. Apart from their clients in court, and the burghers, nobles, peasants and clergy they represented before municipal offices, these lawyers also often represented absent parties or accompanied clients during a trial (prolocutor, prelocutor, procurator, causidicus), wielding a general or limited power of attorney in a specific case. In many cases, such functions were entrusted to relatives and neighbors. ${ }^{149}$

In contrast to medium-sized and small towns, in Krakow a group of professional court deputies was established in the mid-fourteenth century. Peter and Lawrence were not the only ones to appear as prolocutores in fifteenth-century municipal books, but they certainly appeared most frequently in them. ${ }^{150}$

144 SCAB. 6, fol. 113 (1435); SCAB. 7, fol. 303-304 (1457); SCAB. 8, fol. 466 (1472); SCAB. 8, fol. 501-5O2 (1473); LT, fol. 105 (1472).

145 On the earnings, sources of income and social status of municipal notaries cf. Agnieszka Bartoszewicz, Piśmienność (2012), 152-165; Jacek Wiesiołowski, Socjotopografia, 124-128; Bożena Wyrozumska, Kancelaria, 25-27.

146 SCAB. 7, fol. 120.

147 Agnieszka Bartoszewicz, Piśmienność (2012), 62-64; Jacek Wiesiołowski, Socjotopografia, 124-128.

148 In his will of 1435 , his bequests do not yet indicate his wealth; only entries in the books of the bench court made 38 years later indicate the significant wealth he had accumulated over the course of his long life; SCAB. 6, fol. 113 (1435); SCAB. 8, fol. 5O1-5O2 (1473).

149 Agnieszka Bartoszewicz, Piśmienność (2012), 198; Józef Rafacz, Zastępcy stron w dawnym procesie polskim (Krakow: Gebethner \& Wolff in Komm, 1923), 14-37.

150 Another very active court proxy in Krakow was Rafał from Wielopole (also known as Rafał from Krakow), at the turn of the fifteenth and sixteenth centuries, but there is no information about what he left in his will; cf. Agnieszka Bartoszewicz, Piśmienność (2012), 199-202. 
Prolocutor Lawrence appeared in municipal books for the first time in 1419, when he acted as the plenipotentiary for the parson of Pobiedziska in the will of Peter, a Krakow bathhouse owner. ${ }^{151}$ He then appeared in several dozen entries in both books of the bench court and in council books. He served in court as a guardian or executor of wills. ${ }^{152}$ In 1420 , perhaps after his marriage, he bequeathed all of his property to his wife Margaret. ${ }^{153}$ Four years later, he bought from Michael Krzykawski ${ }^{154}$ a tenement building on Wiślna Street, next door to the bishop's manor house. ${ }^{155}$ For reasons unknown to us, in 1434 the deputy vogt John Hering, acting on behalf of Lawrence, gave this house to the man's wife, Margaret, and a year later the property was sold to the Krakow municipal council. ${ }^{156}$ In that same year, Lawrence bought a house on Bracka Street from councillor Francis Neorza (guardian of the widow and children of a certain Paschek) for 122 grivna. ${ }^{157}$ The coincidence between these dates leads to the conclusion that this transaction with the Council had been previously agreed upon. After obtaining consent from the bench court to dispose of his acquired goods, in 1439 he drew up the first version of his will. ${ }^{158}$ He ordered the sale of a house at Bracka Street, paid 50 grivna to his wife from the dowry he had received, ${ }^{159}$ and confirmed the mutual bequest they had made together with her, ${ }^{160}$ while the rest of the money from the sale of the house and other goods was to be used for works of charity (in German werg der barmherczikeit). Noteworthy are the 20 grivna for "my brothers for the altar [?] to Corpus Christi in the Church of St. Francis" and the five grivna for the brothers to pay for food

$151 \quad$ SCAB. 5 , fol. 2.

$15^{2}$ Eg.: SCAB. 5, fol. 25, 32, 74, 96, 108, 117, 137, 144, 158a, 174; SCAB. 6, fol. 15, 18, 22, 35, 66, 70, 83, 86, 96, 97, 117, 12O, 123, 152, 166, 194, 201, 205, 209, 212, 214, 218, 224, 233, 245, 254, 261; CONS. 428 , fol. 317,381 .

153 SCAB. 5 , fol. 22.

154 Michael Krzykawski must have been a relatively wealthy and respected town citizen, since in 1412 he was the an elder of the salt merchants' guild (salsatorum); cons. 428, fol. 5. Moreover, in 1421 he was mentioned as the keeper of the padlocks for the chains closing Wiślna Street (Secuntur qui habent seras ad cathenas statuarum in platheis...); cons. 428, fol. 164; and, in 1422, he was appointed commander of one of the town's defence towers (CONS. 428, fol. 164); CONS. 428, fol. 188.

155 SCAB. 5 , fol. 93 .

156 SCAB. 5 , fol. 117 .

157 Ibidem.

158 SCAB. 6 , fol. 184 .

159 "L mrc gemeyner muncze das gebe ich ir hewte vor gehegtim dinge"; scAB. 6, fol. 184.

160 "[...] und den brif do wir inne enander of gegeben haben der sal bey craft bleiben und macht haben"; ibidem. 
and running a bathhouse. ${ }^{161}$ This probably concerns the brotherhood of the so-called Hungarian Chapel in the Franciscan church, with which the testator must have been associated. The remaining amounts, totalling 43 grivna, were paid to various church institutions in Krakow and the surrounding area. ${ }^{162} \mathrm{He}$ also ordered six grivna be given to his confessor Jacub Stegen from the castle (of dem hawse) ${ }^{163}$ and ten grivna to his wife's nephew. After his wife's death, everything she left behind was to be used to pay for charitable works. He chose as executors the aforementioned priest Jacob Stegen, Stanisław the pharmacist and John, the owner of a bathhouse in Piasek, and his wife. However, in 1440, a year later, he drew up a new will "for the glory of God and the salvation of his soul" (gote czu lobe und meyner zele czule hulfe). ${ }^{164}$ In it he repeated most of his previous pious bequests, this time making a donation to the fraternity at the Church of the Blessed Virgin Mary and allocating a total of just 24 grivna to 'pious works.' 165 It seems this was associated with the fact that the duty to care for the soul of the deceased was placed in the hands of his wife Margaret. ${ }^{166}$ Based on his bequests, we can see that the value of his estate was close to the amount for which he bought the house on Bracka Street, i.e. about 120 grivna, although perhaps we should also add to this the value of

161 "Item so bescheide ich czu dem heiligen leichnam czu sinte Francisco meynen brudern XX mrc czu dem gebewde und V marg den brudern daz man do von machit eyn essen und czu dem bade"; SCAB. 6, fol. 184; Kazimierz. S. Rosenbaiger, Dzieje Kościota OO. Franciszkanów w Krakowie w wiekach średnich (Krakow: Zakład Narodowy im. Ossolińskich, 1933), 76; Hanna Zaremska, Bractwa, 8o-83.

162 "20 grivna for the construction of St. Mary's Church, 10 grivna to the Dominicans of the Holy Trinity for food and their bathhouse, five grivna to the hospital of the Holy Spirit for food, five grivna to poor leprous women from St. Valentine's Hospital near Krakow and five grivna to poor leprous men from St. Leonard's Hospital near Kazimierz"; scAB. 6, fol. 184 (1439).

163 The phrase of dem hawse was also used in relation to the Higher Court of Magdeburg Law at the Krakow castle and, for example, to vicars of the Wawel Cathedral (vicarien of dem hawse); cf. SСAB. 6, fol. 178 (1439), 262 (1442). "Item so bescheide ich unsern Beich vater her Jocob Stegen of dem hawse VI mrc of das daz her got vor uns bete in der messe”; SCAB. 6, fol. 184 (1439).

164 SCAB. 6, fol. 213.

165 He left 10 grivna to the Franciscans for the construction of their church, five grivna to the brotherhood of the Blessed Virgin Mary ("Item der Bruderschaft czu unser Frawen czu stewir des dinstis unser liben frrawen V marg”), three grivna to lepers from outside Krakow for construction or other needs, three grivna to lepers from outside Kazimierz for construction or other needs, three grivna for poor patients at Krakow hospital for food; SCAB. 6, fol. 213 .

166 " [...] befele is Margarethe meyner hausfrawen in deme getrawen das ich czu irre trew habe, daz sy meynir zele dovon getrewlich gut tuen sal"; sCAB. 6, fol. 213. 
clothing and other personal belongings that were not mentioned in any versions of his will.

Although Peter Streicher, a court plenipotentiary, held functions similar to Lawrence in the city, he was undoubtedly less wealthy. His weaker position is indicated both by the smaller number of cases recorded in the municipal books (from 1411 to 1437 ) in which he appeared, ${ }^{167}$ and by his more modest estate, which we learn about mainly in his will, written in 1418, when five councillors came to the ailing burgher. ${ }^{168}$ Most of the bequests mentioned in the will were to be given to the testator's brother "Matthias, a carpenter from Pilzen." The donation was made up of cash deposited with a certain John Teuderneuder and items of clothing and weaponry, listed in detail. ${ }^{169}$ In addition, all Streicher's silver, which was also under the care of John Teuderneuder, was to be used for the creation of a chalice to be donated to the monastery of St. Mark. Peter also testified that when he married his wife, he did not bequeath any dower money to her, so, as he lay sick, he decided to give her his best blue gown and half of his house on Mirror Street (in German Spiegler Gasse, in Latin Platea Specultorum) in Krakow. ${ }^{170}$ The other half of the house was to be leased out for rent, and after her death, part of this property was to be given to his brother Matthias. From the entry preserved in the Krakow municipal book of the bench court, we learn that Peter's house, located alongside Mirror Street, was burdened by a rent of sixty groszy, which reduced the value of the property itself, which was probably not very high. ${ }^{171}$

167 SCAB. 4, fol. 43, 53, 6о, 9o; SCAB. 5, fol. 21, 75, 121, 172; SCAB. 6, fol. 92, 99, $113,141$.

168 That will was probably copied to the council book from the first book of wills, which was not preserved, as indicated by the beginning of the entry: "Copia Testamenti Petri Prolocutoris. Petir Fochsczagil, Michil Neudorff, Caspar Bozmecz, Petris Fetter i Petrus Kaldherberg Rathmannen der Stat Cracow Bekenne allen den is notdorfft wirt seyn, das in unsers Rathis keginwortikeit, die ersamen Georgius Morrensteyn czu der czeit Burgermeister und Johannes Faber unser Rathman und eitgenosen und haben bekant offinbar und mit laute, das als sie von unser bevelunge in krafft unsers und ihres Rathampts czu Petro vorspreche seyne meynunge czu vorhoren gegangen weren, do hette her derselbe Petrus vor en seyn Testamenth und lecztin willen gemacht und geschikit in sulche weyse"; CONS. 428 , fol. 125 .

169 "Czu dem irsten eynen swarczen Rok mit Weysen Lempinern undirsatter, eyne swarczen mantil desselben gewandis, eynen Roten mantil, eynen gefutirtin, eynen grunen Breslichen Rok, eyn groen Engilischis gewandis Rokmit czweliche gefutirte, czwer swert, czwee brostblech, eynen ysenhut, eyn par eyserinen hanczken, eyne swarcze kogil, eyne rote mocze, und drey par hozen"; ibidem.

170 “[... off seyne leczte fart genomen, die seyne sele faren sulde, das her ir keynen pfening noch pfeningis wert gemorgengobit hette, wenne her betwungen werre mit dem rechten dorczu sie czu nemen"; ibidem. 


\subsection{Other Crafts}

The remaining thirty crafts listed in Table 2 were represented by only one, two or three testators each. Therefore, in these cases one can speak both of their incidental character and the fact that they comprise most of the 'typical' craft occupations, including coopers, blacksmiths, cutlers, tanners, wheelwrights, weavers and carpenters. The relatively low number of representatives of these crafts among testators indicates that their decision to write a will was more likely influenced by personal factors and exceptional circumstances than by their belonging to a particular professional or social group. The presumed affiliation of people in this group with a particular craft is often indicated only by their nickname or surname. This was the case with the wealthy Dorothy Stelmecherinne (the surname meaning 'wife of a wheelwright'), who owned two houses at St. Florian Street and two stalls, ${ }^{172}$ or Margaret Glezerinne, widow of counciller Nicholas Glezer (meaning 'glazier'). ${ }^{173}$ As in the case of the abovementioned professions, many of the $5^{8}$ people representing these $3^{1}$ professions belonged to a kind of 'craftsmen's elite,' and had for many years served as elders in their guilds and confraternities. ${ }^{174}$ The unique position they held in their social and professional environment and their related ambitions to participate in writing culture and in the founding and religious activities of the municipal elite seems to have led them to be more interested than their fellow guild members in settling accounts with their loved ones and with God by means of a will.

In many cases, it is likely that individual and chance circumstances also determined that some relatively poor craftsmen are found among the group of testators under discussion. An interesting example is undoubtedly the Krakow's citizen Martin the bricklayer. His will, made before the town council, was entered into the Liber Testamentorum in $1464 .{ }^{175}$ The first mention of him comes from 1446, when he bought a house on St. John Street for 40 grivna from Andrew Radwanowicz; ${ }^{176}$ in the same year, he also obtained city citizenship,

\footnotetext{
172 SCAB. 6, fol. 202 (1440), 225 (1441).

173 CONS. 428 , fol. 243 (1428).

174 For example, Stephen the furrier, who left two versions of his will, served as an elder of the guild of Krakow furriers in the years 1410, 1415, 1429 and 1437; cf. CONS. 427, fol. 357; CONS. 428, fol. 70-72, 246, 370. Nicholas Czeginkop was an elder of the guild of German shoemakers in the years 1403 and 1417; cf. CONs. 427, fol. 173-174; CONs. 428, fol. 96-98, and Nicholas Clingsor was elected as an elder of the bakers' guild in the years 1431, 1433 and 1435; cf. cons. 428, fol. 288, 315, 336 .

175 LT, fol. 82.

176 sCAв. 6 , fol. 351,356 .
} 
paying a relatively sizable fee of 17 skojecs (i.e. 34 groszy). ${ }^{177}$ In his will, which he made before leaving on an expedition against the Turks, he bequeathed a dower of 15 grivna to his wife Margaret (secured by his house by the Gate of St. Nicholas), ${ }^{178}$ together with all his household goods and personal belongings (in Latin suppellectilibus et parafernalibus). If, however, his wife died before him, her son from her first marriage was to receive 10 grivna. Martin also made a bequest of five grivna to St. Nicholas Church (most likely his parish church) and another five grivna to the Polish Brotherhood in this church. The second part of this will is very interesting. In it he points out that if his uncle (avunculus) the noble John Banczelski came to Krakow and obtained city citizenship, he would have the right to live in this house and would have preemptive rights to its purchase. ${ }^{179}$ Martin chose as executors John Raciborski the blacksmith, John Orł the dyer, and Nicholas the municipal carpenter (Latin carpentarius civitatis) - people who, by virtue of their profession, could have been suburban burghers, like the testator himself. The figure of Martin the bricklayer is extremely interesting both because of his participation in the military expedition against the Turks and because of his blood ties to nobility. One ambiguity here is the readiness expressed in the will to respect relatives' right of inheritance, which in Martin's case manifests itself in his imposing conditions on his uncle to come to the city and obtain city citizenship, which would have merely given him preemptive rights in the purchase of Martin's house outside the city, worth around 25 grivna.

\subsection{Summary: Trade and Handicraft}

As can be seen from this analysis, the dominant position among testators was held by people engaged in trade, although clear professional classifications here are very difficult to make, even when the burghers served as elders or

177 Book of Admissions, no. 5649 .

178 "[... ] ante walvam sancti Nicolai circa ortum Orientin sita" - the expression 'ante valvam' suggests that the house was located within the city walls, but the specifying comment 'circa ortum Orientin sita' points to its suburban location. It is probably the garden next to St. Nicholas' Church, the ownership of which was transferred for 20 grivna from councilor Marek, a needle maker (noldenfesser), to councilor George Orient together with a house, barn and half a grivna for rent to support this church in 1442; SCAB. 6, fol. 261.

179 "Ita tamen si nobilem Johannem Banczelszky dicti Martini avunculum advenire contingerit et Ius Civitatis conquesierit, liberum sit ei in eadem domo demorari et eadem non alteri quam uni ex concivibus vendendi. Et omnia testata atque legata prout super descripta sunt expedire et solvere cum effectum, Si autem domum ipse Johannes habere noluerit, extunc executores, ipsius infranominati plenam et omnimodam proprietatem habebunt domum prememoratam vendendi et de pecuniis disponendi iuxta testamentaliter legata ipsius conmissaet descripta solvendi"; LT, fol. 82. 
masters in their guilds. In terms of the social advancement that seems to have occurred among a significant portion of testators, it is clear that changing one's occupational affiliation was possible, including one's belonging to a given guild. This was often reflected in the abandonment of handicrafts in favour of commercial activity, with burghers usually making such a change in an effort to diversify their sources of income. For many craftsmen, their handicraft and commercial activity were intrinsically linked. The social position they held, between the patricians and commoners, between trade and the crafts, often led to tensions, and even to outbreaks of social unrest. However, it is significant that the main participants in these events tended to be same professional groups: butchers, maltsters and brewers, as well as goldsmiths, furriers, tailors and cloth makers. ${ }^{180}$ It seems that these members of the urban community could be counted among the most socially mobile individuals, and the one's with the greatest chances of crossing group and class lines (if not in the first, then in the second generation).

\section{5}

The Financial Situation of Krakovian Testators

There are two categories of sources which allow us to assess with a high degree of accuracy the financial situation of Krakow's burghers: the city's szos tax

180 As Henryk Samsonowicz noted, "of greater importance for the shaping of power in the city was the fight between the opposition and the Patrician council. Since the mid-fourteenth century, they had been a permanent part of urban life in Central Europe. This was not a struggle between two classes; it was an attempt by people and groups that were growing wealthy quickly and trying to gain access to power and its benefits"; Maria Bogucka, Henryk Samsonowicz, Dzieje miast, 163-167; Hanna Zaremska, on the other hand, while describing the aspirations of wealthy representatives of Krakow's craftsmen, wrote: "They placed their chapels in the main churches. They started brawls over their place in processions $[\ldots]$. The statutes of their guilds often mention the importance of a decent appearance and proper clothing. Butchers, goldsmiths, furriers, cloth makers - the aristocracy of 'producers' - their organizations were associated with the main churches, while others relied on communities in their own parish churches"; eadem, Bractwa, 102-106; more on social conflicts in the late medieval and early modern cities of the Kingdom of Poland cf. Ryszard Szczygieł, "Wpływ konfliktów wewnętrznych w miastach polskich XV-XVI wieku na zmiany struktur społecznych," in Stare i nowe struktury społeczne w Polsce, vol. 1: Miasto, ed. Irena Machaj, Józef Styk (Lublin: Uniwersytet Marii Curie-Skłodowskiej, 1994), 40-41; idem, "Konflikty społeczne w miastach Królestwa Polskiego w XV i XVI wieku związane z dostępem do władz miejskich," Socium 7, 35-42; Janusz Tandecki, Struktury administracyjne i spoteczne, 82-88; Edmund Cieślak, Walki ustrojowe, 20-21; Antoni Gąsiorowski, Walki o wtadzę, 256-259. 
register and records of the size of dowers contained in marriage contracts. ${ }^{181}$ In the first case, unfortunately, the szos registers for medieval Krakow, which would enable relatively precise research on the 'socio-topography' of the city and the asset diversity of its inhabitants, have not been preserved. ${ }^{182}$ We do have, however, the municipal statute (German Willkür) announced in 1385 by the municipal council concerning the rules for the collection of this tax from Krakow's burghers. ${ }^{183}$ The tax rate was based on a burgher's wealth, taking into account his real estate, capital, and receivables, as well as the location of his home and his livelihood. ${ }^{184}$ Stanisław Kutrzeba distinguished three bases for the city's annual income: a land and residential property tax, a tax on profits from trade and production activities, and a tax on assets. ${ }^{185}$ In the first case, a fee was charged based on the size and location of a parcel of land owned within the city walls. On the basis of a so-called 'city plot' (in German ein gantczer hof), measuring 36 cubits wide and 72 cubits long, a fee was collected based on its location in relation to the market square. For parcels on the market square itself, one paid 24 groszy, for a parcel up to the first junction (krewtcze) from the market square - 16 groszy, and for plots located between the first junction and the city walls -12 groszy. ${ }^{186}$ Such evidence of the differing values of urban property is an important prerequisite for assessing the wealth of testators who owned houses in particular parts of the city. Anything that might have been used as an element of exchange or trade or provide some other source of income was taken into account when taxing such property. Horses, cattle, pigs, grain and meat were excluded from these goods and were instead classified as personal property that was kept for "a hard times" (farende habe [...] czu schlechter notdorfft); also excluded were objects usually classified as the personal property of a woman (gerada) or man (hergewet), described in the municipal statute as items for personal use, like 'jewellery.' The third part of

181 Jacek Wiesiołowski, "Stratyfikacja mieszczaństwa polskiego w późnym średniowieczu," in Struktura feudální společnosti na území Československa a Polska do přelomu 15. a 16. stoleti, ed. Ján Čierny, František Hejl, Antonín Verbík (Praha: Ústav československých a světových dějin Československé akademie věd, 1984), 278; Antoni Czacharowski, Ze studiów, 89-9o.

182 Marcin Starzyński, "Nad średniowiecznymi księgami rachunkowymi miasta Krakowa," Roczniki Historyczne 74 (2008), 165-178.

183 KDMK, vol. 2, no. 277 .

184 Jacek Wiesiołowski, Stratyfikacja mieszczaństwa polskiego, 279.

185 Stanisław Kutrzeba, Finanse i handel średniowiecznego Krakowa, 69.

186 A judgement of this kind also included changes in the size of the plot, and its enlargement or reduction in relation to its original size. The tax depended on what part of a standard urban plot they constituted (noch deme das erbe kleyn ader grosz were). Neither the size nor the structure of the house on the plot were taken into account. It was probably included in the property tax, which was $1 / 2$ grosz for each grivna, i.e. 48 groszy. 
the szos was a 12 groszy tax on shops (von der kauffkammern), and 6 groszy on stalls (von der cremen), butchers' stalls (von der fleischbencken) and 'benches' (von dem tissche). Those who had neither "inherited property" nor assets worth more than 12 grivna were to pay based on their point of sale. This tax was therefore primarily intended to tax the poorest city inhabitants who, lacking any major assets, made a living from retail trade. This is also an important source of information about the 'poverty line' in Krakow in the late fourteenth century. These rules for the taxation of burghers remained in use with only minor changes throughout the Middle Ages. ${ }^{187}$

\section{Social Structure in Other Cities and Towns}

Given the lack of szos registers for Krakow, a valuable reference would be the comparativestudies oflatemedievalWrocław conductedby Mateusz Goliński. ${ }^{188}$ In the latter half of the fourteenth century, Wrocław councillors introduced a new tax system under which the property tax was five times less than that in Krakow (only one grosz for each 10 grivna), while the money invested in rents was subject to a tax of as much as one grosz for each grivna in rent. ${ }^{189}$ Testifying to the divisions within the Wrocław municipality was the principle introduced between 1357 and 1374 that the richest of the burghers (regardless of the

187 Stanisław Kutrzeba, Finanse i handel, 66-67.

188 The rules for assessing the szos there was like those used in Krakow. They included taxes on real estate and property, but the profession declared by burghers was also taken into account. As in Krakow, taxed goods did not include household appliances, clothes, jewellery or weaponry, as well as reserves of food, meat, beer and grain stored by the owner for their own use. This similarity is hardly surprising given the strong ties between the two cities and the Magdeburg Law governing both of them; Mateusz Goliński, Socjotopografia, 290-291.

189 Such a tax regulation clearly affected the richest part of the city's population, who invested their money in trade and collected rent paid for city property. This intention is also evidenced by the system of non-taxable property thresholds, differentiated "according to the size of the capital needed to set up a workshop in this profession," merchants were exempt from taxation of the first 100 grivna, rich stallholders -30 , innkeepers -20 , and craftsmen - 10. The list of these exemptions reflects in itself the awareness that the variability of wealth among the city's inhabitants depended on the way they made their living. This hierarchy is also emphasized by another component of the szos collected in Wrocław: the de opere tax that was paid on the basis of one's occupation. According to the 1384 tax tariff, merchants were to pay 24, innkeepers 12, stallholders 6, butchers 12, bakers, weavers, shoemakers, tanners, maltsters, coopers, blacksmiths, tailors, spinners, hat makers, bathhouse owners, glaziers 6 , furriers, purse makers, cobblers, cutlers, locksmiths, belt makers, linen merchants 4 , and other crafts 2 groszy each; ibidem. 
activities they were engaged in), in other words those who owned property 190 worth at least 240 grivna, would settle their obligations to the city in person in the town hall, while other taxpayers would be visited by town officials in their homes, in accordance with the existing practice. At the same time, burghers who did not reach this 240-grivna ceiling had the szos tax they were to pay reduced by half ( 0.5 grosz for each ten grivna of property owned and 0.5 grosz for each grivna in rent). This - quite complicated - tax system was aimed at the legal separation of two social groups that lived within the urban community. Rich burghers were charged a higher tax, but at the same time, they were allowed to make a private, 'dignified' settlement and payment of their obligations. This also reflected the ideological balance between the few 'honourable' inhabitants of the city (approximately $6.7 \%$ of the total) and 'ordinary' burghers, because both classes of tax were supposed to generate the same level of revenue for the city despite the disparity in wealth between the two groups. ${ }^{191}$

The layered, 'pyramidal' structure of late medieval urban society is also evidenced by research carried out on the inhabitants of other large cities in the Hanseatic region. Roman Czaja compared the military burdens imposed on the city of Elblagg's burghers in the early fifteenth century with data on their real estate in 'land books.' ${ }^{192}$ This allowed him to classify the burghers into three strata, each of which was divided into an upper and a lower group. In the early fifteenth century, Elblagg's population "had a wealth structure typical of Hanseatic cities sustained by long-distance trade" and was characterised by a relatively large group of wealthy burghers $(14 \%-4 \%$ in the upper and $10 \%$ in the lower group) and a significant group of middle-income burghers $(28 \%-18 \%$ in the upper and $10 \%$ in the lower), while the largest group was comprised of the poorest burghers (58\%). In the latter half of this century, the gap in property ownership between burghers in the different strata widened significantly, with

190 Considered was taxable property, without the above-mentioned tax exemption, which meant, in the case of e.g. merchants and stallholders, a minimum of 340 and 270 grivna, respectively; ibidem.

191 A comparison of estimated numbers of both categories of taxpayers - about 209 representatives in the higher tax group (citizens) and about 2900 taxpayers, men and women, in the lower group ( $6.7 \%$ to $85 \%$ of the population identifiable in sources) gives an idea of the diversity in terms of wealth among the inhabitants of Wrocław. An Average wealthy burgher paid almost 17 times higher taxes than their average fellow resident from a lower tax class, while the differences between the their property and income must have been even higher; ibidem, 301 .

192 Roman Czaja, Socjotopografia miasta Elblaga w średniowieczu (Toruń: Wydawn. Adam marszałek, 1992), 38 . 
the poorest group of burghers now accounting for $64 \%$ of Elblagg's population. ${ }^{193}$ This reconstruction is supported by similar models of the wealth structures of other fifteenth-century Hanseatic cities. ${ }^{194}$

A list of the citizens of Torun's military obligations to the Teutonic Order (a Catholic military and religious order founded in 1192 in Acre and settled from 1226 in Prussia) was used by Antoni Czacharowski to study the wealth structure of the city's society at the turn of the fourteenth century. ${ }^{195}$ From this he identified four subgroups among the "wealthiest groups of Torun's society." The first and most affluent group - comprising $19 \%$ of the sample - consisted mainly of wealthy merchants, including representatives of the patricians, but also a few of the richest craftsmen (a saddler, a goldsmith and a tailor) and one innkeeper. The second group in terms of wealth included $36 \%$ of all taxed individuals and consisted of less wealthy merchants, rich craftsmen (such as tinsmiths, blacksmiths, goldsmiths, armourers) and nineteen innkeepers. The third group $-20 \%$ - consisted mainly of craftsmen (furriers, saddlers, goldsmiths, glaziers, tinsmiths and some bakers) and innkeepers. The fourth group, which included $25 \%$ of all the persons mentioned, was in actuality much more numerous, as it also included poor craftsmen who were not mentioned by name in the census. It was made up of bakers, wheelwrights, shepherds, belt makers and 26 stallholders. ${ }^{196}$

The data collected from relevant literature on the subject and presented in Table 3 show significant differences between the estimated size of the

TABLE 3 Estimated distribution of the three social strata in Rostock, Stralsund, Lübeck, Wrocław, Torun, and Elblag

\begin{tabular}{lrcc}
\hline & Upper strata & Middle strata & Lower strata \\
\hline Rostok & $7 \%$ & $38 \%$ & $55^{\%}$ \\
Stralsund & $12 \%$ & $32 \%$ & $56 \%$ \\
Lübeck & $18 \%$ & $30 \%$ & $52 \%$ \\
Wrocław & $15,8 \%$ & $84,2 \%$ & $52 \%$ \\
Toruń & $18,7 \%$ & $29,3 \%$ & $58 \%$ \\
Ebląg & $14 \%$ & $28 \%$ & \\
\hline
\end{tabular}

193 Ibidem, 42-45.

194 Approx. 7, 38 and 55\% respectively for Rostock in 1430, 12, 32 and 56\% for Stralsund $1405^{-}$ 1409, and about 18, 3 o and 52\% for Lübeck in 146o; as in Roman Czaja, Socjotopografia, 45.

195 Antoni Czacharowski, Ze studiów, 89-96.

196 Ibidem, 94. 
social strata in particular cities. They are related both to the different research methodologies adopted and to the different types of sources available to the researchers. The specificity and size of each of these cities is also of no less importance. ${ }^{197}$ Taking into account the reservations above, it seems justified, however, to adopt a model of a large late-medieval city in which the upper strata was formed by about $10-15 \%$ of its inhabitants, the middle strata by about $30 \%$, and the lower strata by about $55^{-6 \circ \%}$. The complicated nature of the actual social relations means that this division into layers is something of a simplification, but it allows us to see the vertical structure of wealth in urban society and the significant differences in terms of the level of affluence among these particular groups, which are traditionally referred to as patricians, commoners and plebeians. Social divisions based on financial status determined in large part both the social prestige and self-identification of individuals: only the richest burghers and their close relatives had access to holding municipal offices, the nature of one's work determined the 'nobility' of one's profession, personal wealth determined the burden of city taxes and therefore the individual support of the city's finances, and sumptuary laws restrained individuals from making inordinate displays of wealth through their choice of attire.

\section{7}

\section{Wealth and Social Status}

The divisions between the rulers and the ruled, as well as between large-scale trade and small-scale handicraft resulted in enormous differences in wealth among Krakovian burghers. ${ }^{198}$ In no other environment was 'hard cash' such a key to social advancement as in the city:

With some exceptions (Jews or foreigners), material conditions always take precedence over social status, determining levels of respect or contempt. With certain periodic exceptions, money makes it possible to move from craftsmanship to the world of business, to gain entry into the

\footnotetext{
197 There was a much smaller higher stratum in Rostock and Lübeck, compared to other cities listed on this table, probably due to the fact that it only contains the richest burghers, so-called patricians, who made up the upper group of the upper strata in the six-group division. The upper lower group was included in the wider middle stratum.

198 "Differences in status, origin, social status, or, in short, qualitative differences, created social divisions which overlapped with property divisions. Moreover, the urban social model was still bourgeois and the basic factor influencing social diversification was money"; Jacques Rossiaud, Mieszczanin i życie w mieście, 191 (J. Rossiaud, Le Citadin).
} 
Hanseatic League, to markets, to a place among the rich, and finally even into the ranks of the city elite. 199

In the late medieval Kingdom of Poland, it was even common for the wealthiest Krakovian burghers to be raised to the rank of nobility. 200

The data emerging from analyses of tax records from other late-medieval towns in the region can only serve as a reference point for research on Krakow's inhabitants. The lack of a source base allowing for easy comparisons means that in principle the only type of sources enabling an even fragmentary reconstruction of the social structure in the city are records reflecting marital contracts that were concluded there, i.e. dower records. It is assumed in the literature that these records provide a relatively faithful picture of the economic situation of the spouses involved, smoothing out short-term rises and falls in the wealth of the townspeople or their exemption from rent payments, which could affect, for example, the szos register for particular years. ${ }^{201}$ The usefulness of these source records for research on the social structure of the city was proven by Jacek Wiesiołowski, who used the example of late medieval Poznan. In libri resignationes from the years 1430-1499, he found over 2000 dower records made by Poznan's burghers. This allowed him to carry out an exemplary study of the city's social hierarchy and socio-topography. ${ }^{202}$ His research showed that over this period, the median value of bequests changed little, increasing from fifteen to 24 grivna at the end of the century. ${ }^{203}$ At the same time, the arithmetic mean of bequests grew almost continuously from 22 to 65 grivna, an indication of the growing stratification of wealth and the increase in the concentration of wealth in the hands of the richest burghers during the fifteenth century. ${ }^{204}$

In municipal sources from Krakow we find only occasionally entries concerning the means for securing the money promised to future wifes. For the

\section{Ibidem.}

200 Zdzisław Noga, Krakowska rada miejska w XVI wieku. Studium o elicie wtadzy (Krakow: Wydawnictwo Naukowe Akademii Pedagogicznej, 2003).

201 This phenomenon is indicated, for example, by szos registers from Kazimierz in Krakow from the years $1385^{-1387}$, where 353,406 and $33^{8}$ people paid the szos tax. Also in Olkusz, in the years $1455^{-1456}$, there were 197 and 110 szos taxpayers. Significant differences in the number of burghers taxed were also found in Lviv in the years 1406-1417; cf. Jacek Wiesiołowski, Stratyfikacja mieszczaństwa polskiego, 280; Danuta Molenda, Dzieje Olkusza do 1795 roku, in Dzieje Olkusza i regionu olkuskiego, 171.

202 Jacek Wiesiołowski, Socjotopografia

203 Ibidem, 16.

204 Ibidem, $15^{-25}$. 
years 1300-1500, only eighty bequests of this type were found in municipal books (both in books of the bench court and city council). At the same time, most of these dowers were very high (100-200 grivna), and in some cases dowers were given in the form of real estate, a house, a stall or a garden (or part of one), whose value is difficult to estimate precisely.

Dower Records in Krakovian Wills

A lack of sufficient sources makes it impossible to conduct detailed research on the social structure of Krakow. It seems, however, that dower bequests fulfilled a function similar to that of burgher wills. Confirmation of the amount of the dower promised to a wife and the rules for the division of property between spouses (and their descendants) in the event of the death of one of them - evidence of marriage contracts that had been concluded - constituted a frequently occurring element in burgher wills. The fact that the municipal authorities merged these two forms of documents is evidenced by, among other things, information that in 1396 the Krakow municipal council established the first, now-lost book of wills, referred to as Liber Testamentorum et dotaliciorum - the book of wills and dowers. ${ }^{205}$

Research has allowed us to identify 125 wills containing information about the amount of a dower due to a wife, constituting about $25 \%$ of all acts of last will, and $37 \%$ of those wills written by men. For the majority of the remaining $63 \%$ of wills, the widow's economic security usually consisted of a bequest for a specific part of the testator's estate (usually one-half, one-third, or a part equal to that received by each of the children) and bequests of property as a dower, with no indication of its estimated value, which made it impossible to use it for this purpose.

Limitations related to the statistical use of dower bequests for assessing the wealth, and thus the social position, of testators can in part be compensated for by prosopographic research on selected individuals. Despite widely shared views on the fundamental usefulness of dower bequests in research on the social structure of late medieval cities, it should be stressed that the amount given as a dower in each case varied according to a wide range of factors, including some very obvious ones, such as the economic situation of the husband's

205 Registra perceptorum et distributorum civitatis Cracoviensis annorum 1390-1393, 1395-1405 nec non 1407-1410, ed. Franciszek Piekosiński, in Libri antiquissimi civitatis Cracoviae saeculi decimi quinti, pars posteriori, Krakow 1877,313 . The fact that the book was still in use in 1410 is proven by an entry in the council book; CONS. 427 , fol. 371. 
and wife's families, as well as whether it was their first or successive marriage, or whether either of them had received an inheritance from their parents or relatives. Moreover, the difference between a will made in the municipal book shortly after marriage and a will written at a dying man's bedside was often a reflection of the passage of time, during which the property and personal and social positions of the spouses could have changed significantly. The emotional relations between them greatly influenced the final dispositions made to one or both of them. An example of this is undoubtedly the frequently enlarged dowers, so-called dotalicium, which sometimes increased the amount due to the wife after the death of her husband by two- or three-fold. However, the institution of the dotalicium itself shows that the initial amount of the dower, which was a very important part of the marriage contract, was remembered and probably sometimes secured in writing, and any increase was usually added to the initial amount. ${ }^{206}$

Since one quarter of all the preserved wills constitute a relatively representative source base, these were compared with the data collected by Jacek Wiesiołowski for fifteenth-century Poznan. The aim of this exercise was to determine the wealth and, consequently, the social position occupied by this group of testators. To some extent, the results of this analysis should also be representative of the entire group of Krakow testators from the fourteenth and fifteenth centuries, who were divided into six income groups according to the model proposed by Wiesiołowski. ${ }^{207}$

The data collected in Table 4 allow us to see the exceptionally stratified nature of testators' wealth throughout the entire period under study. Upper upper-income testators were responsible for at least half of all the acts of last will produced, and together with lower upper-income testators account for as

206 Bartłomiej Groicki wrote about an unspecified but pledged security of the dower in the latter half of the sixteenth century. He considered this practice a fraud committed by women who "cast aside their fear of God, shame, faith and marital duty, having forgotten their children's children, dared to oppose their consciences and evidence, to demand large sums of money which had never been promised them at the time of their marriage; Thus they deprived their children or their husbands' friends out of a large part of their hereditary goods contrary to God's will, claiming this promised dower from their husbands' property"; idem, Tytuty prawa majdeburskiego (Warszawa: Wydawnictwo Prawnicze, 1954), 62.

207 Each of them was divided into a higher and a lower group. "The convertibility of the six groups and the flexibility of the system are the factors that justify this division. The two groups in the upper strata allow for a precise definition of phenomena among urban patricians, the diversity of the Poznan populace is reflected in the three groups encompassing average burghers (the entire middle strata and the upper group of the lower strata), while all of the plebs, which are rarely mentioned in the sources, belong to the lower part of the lower layer"; idem, Socjotopografia, 13. 


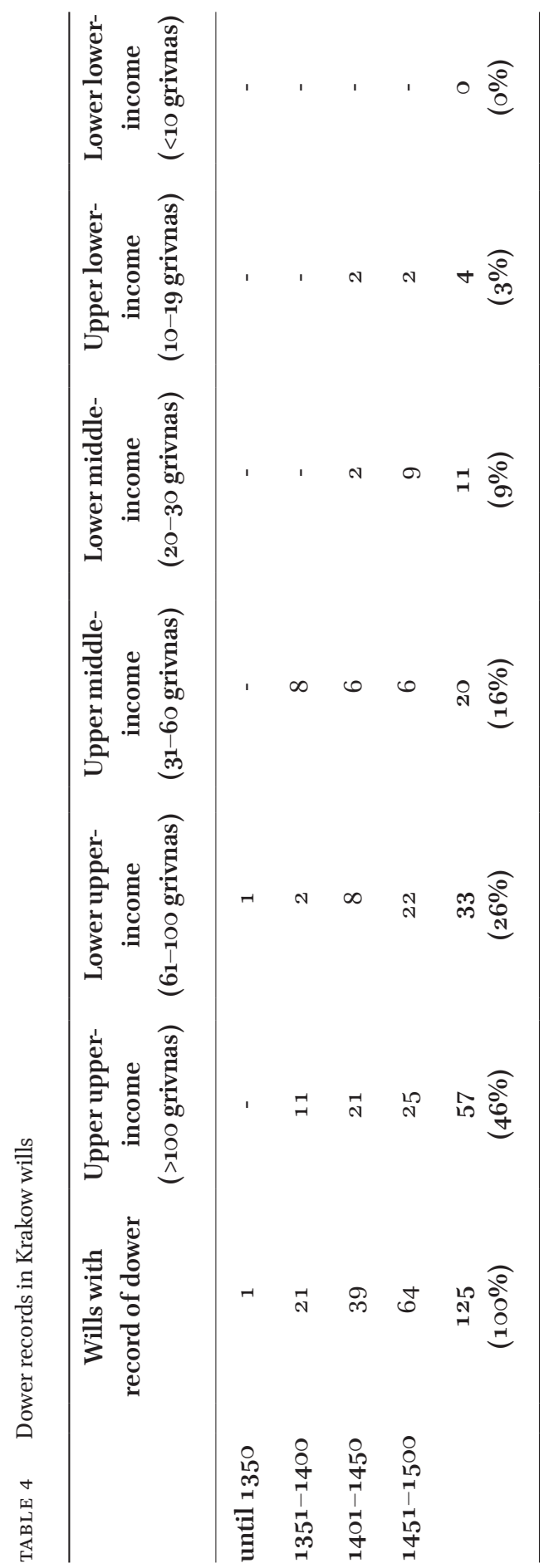


much as $72 \%$ of all the wills analysed (9o out of 125 ). $25 \%$ of these acts of last will (31 out of 125) were written by representatives of the middle-income (upper and lower groups), and only in four cases (3\%) were testators from the lower-income groups. If, in line with Wiesiołowski's proposal, we apply this division to the traditional tripartite model of urban society, which differentiates between patricians, the general population (commoners) and plebeians, this means that representatives of the city's elite wrote almost three quarters of all the wills under discussion, while members of the financially and socially diverse general population made one quarter of the wills, and only in four cases ( $3 \%$ of all wills) can we assume that the testators were from among the poorest burghers, and thus classified as plebeians. In this group, however, there are very few people whose dowers were less than ten grivna, which would qualify them as belonging to the poorest group of Krakovian burghers.

\section{9}

\section{Estimates of Testators' Wealth}

The wealth of Krakovian testators, and thus the social class they belonged to, was examined above in the case of the one quarter of those whose wills contained dower bequests. A closer examination of the almost 447 testators whose wills have survived to the present day required, however, more detailed prosopographic studies. These made it possible to estimate burghers' assets based both on data contained in the wills themselves and from indirect information found in Krakow's municipal books. When assessing the wealth of each individual, the most important criteria, apart from the above-mentioned dower bequests, included: bequests of money and rent made in wills, properties owned and their location within the city or outside of it, the functions performed on the municipal council, family and geographical origin, occupation and other sources of income.

On the basis of the collected data, the testators were divided according to the previously adopted six-part division, into groups conventionally named the very rich (corresponding to the upper upper-income group), the rich (corresponding to the lower upper-income group), the moderately well-to-do (upper middle-income group), those of modest means (lower middle-income group), and the poor (upper lower-income group). As the above analysis of the dower bequests shows, during the period under study, nobody from among the poorest burghers (those from the lower low-income group) are found among Krakovian testators. Due to the marginal occurrence of wills made by people who, according to Wiesiołowski, would represent a burgher of average means civis medianus (one who would find himself between the upper lower-income 
and lower lower-income groups), the differences between wealthy burghers is more visible in this division.

These groups of testators could be defined using the above criteria as follows:

- the poor: dower bequests between ten and nineteen grivna; cash donations of up to 20 grivna; wooden houses on the city's side streets and outside the city; craftsmen belonging to poor guilds, journeymen, servants, residents of the suburbs and their close relatives and immediate family (wives, children, stepchildren, sons-in-law);

- those of modest means: dower bequests between 20 and 30 grivna; cash donations between 20 and 50 grivna; wooden houses on the city's side streets; guild craftsmen, occasionally elders but of less important guilds, and their close relatives and immediate family (wives, children, stepchildren, sons-in-law);

- those moderately well-to-do: dower bequests between $3^{1}$ and 6o grivna; cash donations between 50 and 100 grivna; wooden houses, real estate on important 'gate' streets in the city, but also on the streets leading off of these streets; guild elders and wealthy craftsmen and their close relatives and immediate family (wives, children, stepchildren, sons-in-law);

- the rich: dower bequests between 61 and 100 grivna; cash donations between 100 and 250 grivna; tenement buildings and other properties in the city on important, 'gateway' streets; aldermen on the bench court, long-time elders in Krakow's wealthy guilds and their close relatives and immediate family (wives, children, stepchildren, sons-in-law);

- the very rich: dower bequests over 100 grivna; cash donations over 250 grivna; tenement buildings and real estate on the market and out to "the first junction" 208 or more than one house in various parts of the city; members of the municipal council and bench court; born into councillor's families and the wealthiest merchant families.

208 "Another division of the space of Krakow were three zones of property tax, based on their rates. This division is found in the De exactione civili 'schoss' judgement from 1385. It defines the tax rates applicable in particular zones, as well as their limits. The first zone included the houses located at the market square, where the tax rates were the highest. The second zone consisted of buildings situated at the market blocks, but separated from the first group by currently non-existant streets running among them, and from the third one by major crossstreets. There the rates were slightly lower. The third zone included the area stretching from the so-called first junction (das erste kreucze), i.e. the first block of the street leading from the market square to the walls. The tax was lowest there"; Piotr Tyszka, Obraz przestrzeni miejskiej Krakowa XIV-XV wieku w świadomości jego mieszkańców (Lublin: Wydawnictwo Uniwersytetu Marii Curie-Skłodowskiej, 2001), 221-229. 


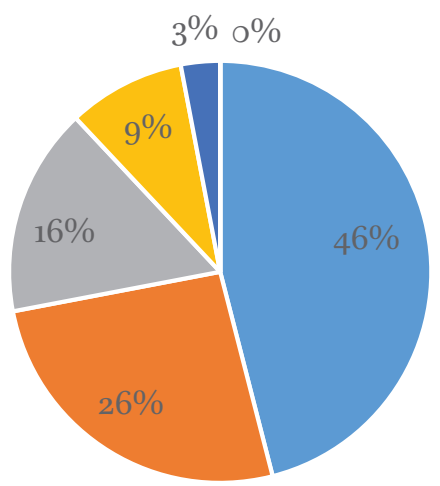
- Upper upper-income
- Lower upper-income
- Upper middle-income
- Lower middle-income
- Upper lower-income
- Lower lower-income

GRAPH 8 Estimates of the wealth of the $25 \%$ of all testators who included dowers in their wills

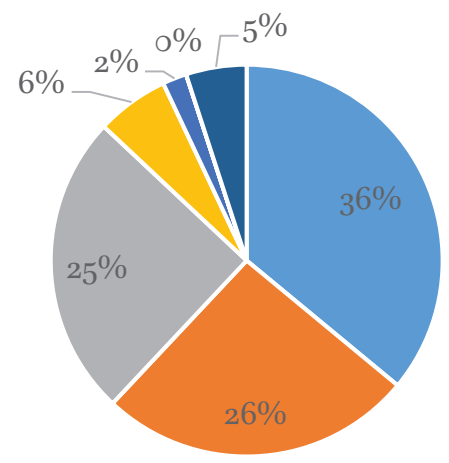

- Upper upper-income

- Lower upper-income

- Upper middle-income

Lower middle-income

- Upper lower-income

n Lower lower-income

- No data

GRAPH 9 Estimates of the wealth of all testators based on indirect information

The rules discussed above for assessing the so-called szos tax indicate (based on the tax levied on poor stallholders) that the 'poverty line' was considered to include those whose estate had a value of less than twelve grivna (they only paid tax on the place of sale as part of the szos tax). ${ }^{209}$ According to the above system of division, the poor peddler would be classified as being in the lower lower-income group. Such poor burghers do not, however, appear among Krakovian testators - at least from what is possible to determine on the basis of surviving wills.

As can be seen from Graphs 8 and 9, estimates of the assets of all the individuals whose wills have been preserved largely coincide with the calculations made for the 125 persons who mentioned in their wills the sum of the dower

209 Stanisław Kutrzeba, Finanse i handel, 69. 
they bequeathed to their wives. Even if we were to take into account the $5 \%$ of individuals for whom source information is insufficient even to allow us to estimate their wealth, and include them in the lowest strata of the urban community, ${ }^{210} 62 \%$ of all wills would have been made by those from the upper strata, about $30 \%$ by persons from the middle section, and only a small percentage would have been made by those from the lower strata. At the same time, the assets of all testators are undoubtedly somewhat underestimated due to the caution exercised in analysing the source references, which in many cases have been preserved in a fragmented state.

The data collected largely confirms the elite social status of Krakovian testators. The vast majority originated from a narrow circle of the richest Krakovian burghers, from among people whose entire estate is difficult to value, but who made dower bequests to their wives many times greater than those of middle-income and lower-income burghers. The income diversity seen among the testators extends along a wide scale, ranging from ten grivna to 1800 florins (about 1350 grivna). It also indicates a growing stratification in terms of wealth among Krakovian burghers. In the first half of the fourteenth century, the largest (and only) dower bequest was 100 grivna; over the next 50 years, 250 grivna; in the first half of the fifteenth century, 750 grivna; and in the latter half of this century, it reached the aforementioned 1800 florins, or 1350 grivna. Nevertheless, representatives not only of Krakow's financial elite and wealthy craftsmen, but also some of the poorer inhabitants of Krakow, made the decision to write a will.

Changes that took place among testators during the analyzed period are presented in the chart below. The initial dominance of wills made by the richest Krakow burghers, usually city officials, council members and aldermen or their close relatives, can be seen here. Over the next fifty years, this initial bias towards wealthy burghers is balanced by a growing number of middleclass testators. Interestingly, Graph 10 clearly shows that, starting in the latter half of the fourteenth century, there is a gradual increase in the number of lower-income testators. Although on a personal level, the making of a last will was decided primarily by individual factors, the collected data testifies to the gradual dissemination of written last will dispositions in wider circles of urban society.

210 Although among them there may also have been some testators who were much more affluent than average; it seems that their absence in Krakow's municipal books indicates their negligible social significance, and since there were no registered commercial transactions on their part, they could not have been wealthy. 


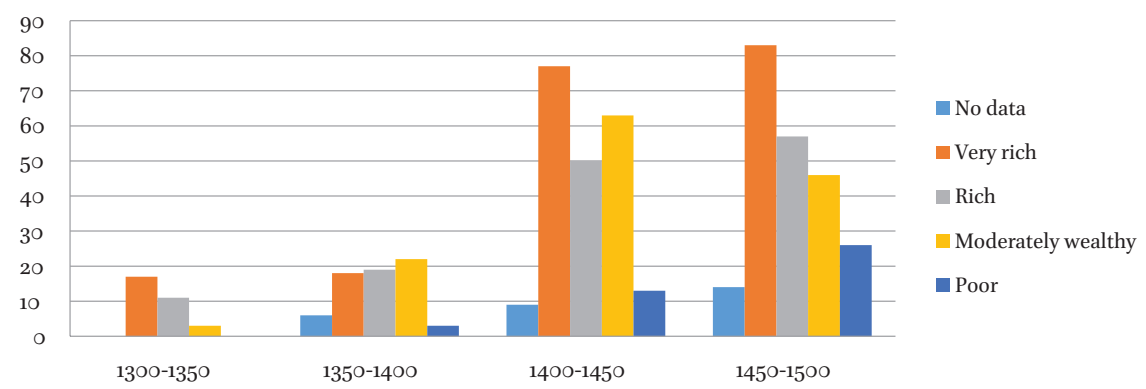

GRAPH 10 Changes in the wealth of testators in the fourteenth and fifteenth centuries.

The breakdown of the wealth of female testators seen in Graph 11 and 12 below, is likewise interesting. These represent members of the same social groups as male testators, but they are to a much greater extent middle-income, and less often very rich burghers. A small shift of just a few percent can be seen over time in each of the three richest social groups. The most significant factor in female Krakovian burghers' decision to write a will appears to have been their becoming widows. Both the need to dispose of part of the property owned by the married couple and the limited possibilities for capital accumulation by unmarried widows were conducive to their pauperisation if they did not re-marry. ${ }^{211}$ The relative lack of wealth among these women was also influenced by the custom and legal principle (not always respected) that real estate - the most valuable property in terms of capital accumulation - was to

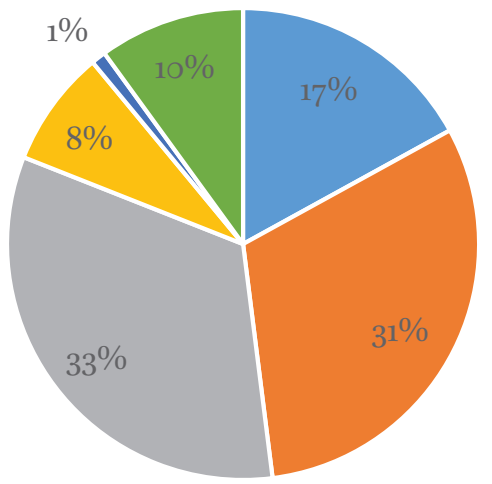

- Upper upper-income

- Lower upper-income

- Upper middle-income

- Lower middle-income

- Upper lower-income

- No data

GRAPH 11 Asset structure of female testators

211 Consequently, the evaluation of a widowed woman's wealth on the basis of the goods she possessed usually indicated a poorer social circle than the one to which she actually belonged. This factor may have had an impact on the possibly underestimated social position of some of them; Andrzej Karpiński, Kobieta w mieście polskim w drugiej połowie XVI iw XVII wieku (Warszawa: Instytut Historii PAN, 1995), 206-207. 


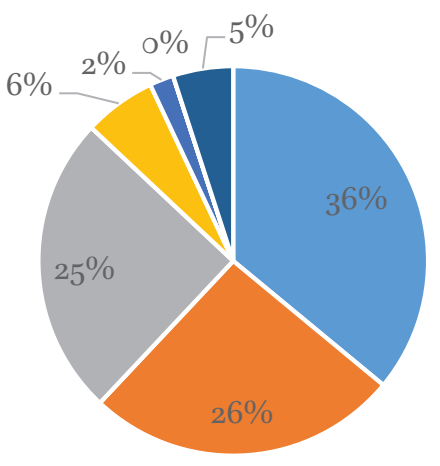

- Upper upper-income

- Lower upper-income

Upper middle-income

- Lower middle-income

- Upper lower-income

- Lower lower-income

- No data

GRAPH 12 Asset structure of all testators

be inherited by sons and other male members of the family, while women were expected to leave the home with the money and valuables they had inherited from their deceased husbands, usually in the form of a dower. It can therefore be assumed that in many cases the economic position of a widow-testator did not reflect her real social position.

\subsection{Impoverished Testators}

Only ten testators whose records of their last will have survived to this day have been classified as poor burghers, i.e. those belonging to the poorest group. ${ }^{212}$ Out of these testators, there were eight men and two women. Amongst the men, there was a butcher, a baker, a stallholder, a bricklayer, a shoemaker, a fustian cutter, a servant at Wawel Castle, and in one case, no information has survived to indicate his occupation. For one female testator, the nickname textrix indicates she worked as a weaver, while another is represented only by her first name and her husband's first name (Anna Gregorinne). Four of these male burghers made dower bequests in their wills: three for ten grivna each and one for fifteen grivna. The possessions of the remaining four male testators were estimated on the basis of their bequests and a small number of entries in municipal books.

\footnotetext{
212 In relation to the system proposed by Jacek Wiesiołowski with three social class layers, each of which was divided into an upper and a lower group, the category of 'poor burgher' corresponds to the lower upper social group.
} 
The baker Piots Ossuch, who made his will during an illness in 1445, noted that Barbara, his daughter from his first marriage, had already been married off and should get one third of the proceeds from the sale of his house, but only if she so requested, while the remaining proceeds should go to his wife and his daughter Martha. ${ }^{213} \mathrm{He}$ had bought the house behind the Rogacka bathhouse in 1428 from the councillor Bernard of Brzeg (who himself had been given it in a court settlement) and declared that he was owed eight grivna for it. ${ }^{214}$ The fact that this was the actual value of the property is confirmed by the fact that in 1449 Barbara, the daughter of the now deceased Peter, received three grivna from her stepmother, in accordance with her father's will, which represented the money she had been promised from the sale of the aforementioned house. ${ }^{215}$ It can therefore be assumed that since the value of the house was 8-9 grivna, the value of the baker's other assets was not much higher.

Among all the fourteenth- and fifteenth-century acts of last will, there is only one made by a journeyman - Johnny from the goldsmiths' guild (in Latin artificii aurificum familiaris), who together with Martin the bricklayer, set out in 1464 on a campaign against the Turks. According to his will, written on a piece of paper, he also had a relatively valuable estate. He left to the guild a sword and six silver skojecs worth together eighteen florins, thirteen silver grivna and all his clothes and other things, which in the event of his death were to be divided into three parts between his brother, sister and pious deeds. He gave his goldsmiths' tools to his relative Wojtek. This will proves that even the goldsmith Johnny, who had not yet started a family, and did not have a house in the city (he probably lived with his master), already had assets worth at least 30 grivna.

\section{$10.2 \quad$ Testators of Modest Means}

Although in terms of the wealth found within the city's overall social structure, burghers of modest means ${ }^{216}$ corresponded most closely with Krakow's commoner class, to which the average burgher (Latin civis medianus) belonged, such individuals comprised only about $6 \%$ of all testators. They made dower bequests in the region of $20-30$ grivna, which is two or three times higher than the amounts recorded by burghers who belonged to the poor, but also two or three times lower than those characteristic of the more affluent burghers of average means.

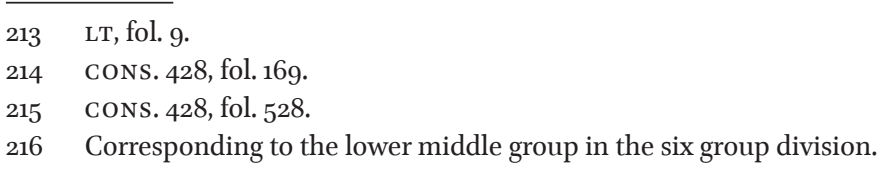


Among twelve of the 32 individuals (37.5\%) for whom dower bequests were known to have been made, five secured them with 30 grivna, two allocated 30 florins (i.e. 22.5 grivna) and five with 20 grivna each. This category also includes a relatively large number of women - eleven (34\%), of whom nine were already widows at the time of the writing of their will. In addition, of the $3^{2}$ wills made by both sexes, seven people $(22 \%)$ made wills before going on a pilgrimage (including all four of those who made wills from the latter half of the fourteenth century). It seems that the nature of these provisions was conducive to the disclosure in the wills of only part of the property owned, the rest having to be spent on travel expenses. The wealth of the remaining nine male testators $(21 \%)$ was estimated on the basis of their bequests and a few entries in municipal books.

John Panzira, elected in 1438, 1451 and 1454 as an elder in the shoemaker's guild, was included among the group of poor citizens. ${ }^{217}$ In his will, written in 1458, before councillors who had come to his home, he gave his second wife Catherine a dower of 30 grivna secured by a wooden house at the corner of St. John Street (opposite St. John's Church). ${ }^{218}$ Due to his stipulation that if his wife did not receive this money, she had the right to lease all his movable and immovable property, it can be assumed that the value of the house was about 30 grivna. In order to secure her future existence, he not only gave her his shoemaker's bench, but also allowed her to work as a shoemaker even after his death, until she found a new husband to take care of her. He also allowed his son-in-law Maciek Bozanczin to live in half the house until John's children from his first marriage reached adulthood. They were to be the final heirs to the house and the shoemaking bench, as well as to other movables, clothing and weapons. A debt of less than six grivna was to be paid after the sale of the first wife's clothing. Two shoemakers were chosen as executors of the will, one of whom was then an elder in the shoemaker's guild. A year later, Catherine, who was now married to Nicholas Mikulka, received the house on St. John Street from the executors and guardians of her first husband's children. ${ }^{219}$

\subsection{Moderately Well-Off Testators}

Among moderately well-off testators (corresponding to the upper middleincome group) were burghers whose assets and social position placed them above those representing the statistical civis medianus. They constituted a large portion of all testators, approximately $25 \%$. They made dower bequests

217 CONS. 428 , fol. 384 ; CONS. 429 , fol. 23,84 .

218 LT, fol. 5 o.

219 Then she sold it to the furrier Nicholas Wolfram; SСAв. 8, fol. 369. 
of between 31 and 6o grivna, which was two to three times the amount pledged by lower-income burghers. Among this group were many wealthy craftsmen and members of older guilds, as well as stallholders, inn-keepers, bathhouse owners and even attorneys.

Among the testators who left relatively numerous entries in municipal books (along with three versions of his last will) was Nicholas Topler. In the will he made in 1450, he divided his personal belongings between his mother and wife Catherine; these included his most valuable clothing (fox fur-lined coats, two newly-dyed tunics and two belts, one of which was gold-plated), cloth (20 ells) and four silver spoons and bowls. He ordered the remaining goods belonging to him to be given after his death to his relatives. ${ }^{220}$ The nature of this bequest suggests that it could have been made, like many other wills in that particular year, before Nicholas's pilgrimage to Rome. His first wife died shortly after his return to Krakow, and in 1455 he made a mutual bequest with his new wife, Margaret. ${ }^{221}$ Another will made by Nicholas Topler dates to 1461 , when he went on another pilgrimage to Rome. ${ }^{222}$ This time, apart from valuable personal property, he also listed a tenement building on Sławkowska Street and a debt of 6 o grivna owed by his sister Barbara, and secured by her house on St. Florian Street. The siblings had inherited these valuable properties after the death of their mother (as Nicholas explains in another document). Before setting off once again, he entrusted his sister and her husband Kacper with the care of his only child, ${ }^{223}$ his daughter Ursula, and financially secured the future of his third wife Catherine, bequeathing her a dower of 60 florins ( 45 grivna) and noting that when he took her for his wife, he received 50 florins from her, of which he still owed her 34 florins. ${ }^{224}$ Moreover, he placed in a box the valuable moveable goods meant to be given to his child and deposited them with his sister, leaving the rest of his household furnishings for his wife's use. Nine years later, Nicholas made a third version of his will, written before councillors when he was lying in a state of infirmity. 25 This last will had a different character from the previous ones, since the first part of it was taken up by a list of debtors and creditors, followed by confirmation of a dower bequest to his wife Catherine

\footnotetext{
220 CONS. 429, fol. 16.

221 SCAB. 7 , fol. 218.

222 LT, fol. 69.

223 This was probably Caspar Topeler, an elder of the tanners' guild in 1459, 1461, 1466 and 1468; cons. 429, fol. 227, 287, 370, 404 .

224 He gave her his yellow marten-lined coat (de coftir) toward repaying this amount, and he was supposed to return the rest if he came back from his pilgrimage.

225 LT, fol. 99-100.
} 
of 6 o florins, absent from earlier versions of the will. Nicholas ordered that two silver spoons and a silver belt be given to St. Bernard's Church and used to make a chalice and a patena (i.e. a plate used in the ceremony of the Eucharist). The will ended with a bequest of rent for his niece and the donation of two houses at Sławkowska and St. Florian Streets to Ursula's daughter.

It is worth noting Nicholas Topler's presumed participation in two pilgrimages to Rome and his three marriages. It can also be assumed that although he had a relatively large estate, he did not achieve much professional or social success in his life. He did not act as the elder of any of Krakow's guilds, and his property did not increase as a result of his actions, but only after his mother inherited a significant sum.

\subsection{Wealthy Testators}

The testators included in the group of rich burghers represented the city's economic and social elite. The amounts of bequests written to wives were usually round sums of 100 florins or 100 grivna, indicating that the value of the testator's entire property was likely at least two or three times higher. In this group, one can already find many aldermen, especially those who had not yet been able to join the city council. There were also many rich guild masters in this group, mainly representatives of profitable professions, such as merchants, goldsmiths, stallholders, furriers, innkeepers and fish merchants, but there were also pressmen, tailors, butchers, shoemakers, captains, wheelwrights and archers. ${ }^{226}$ Among the 137 testators included in this group there were also 36 women $(26 \%$ of the total), most often the well-secured widows of wealthy Krakow burghers.

A typical example of a rich burgher is the goldsmith Nicholas Brenner. ${ }^{227}$ After obtaining citizenship in Krakow in 1440, he was listed in the book of records of new citizens as a goldsmith from Paczków near Nysa. His identity was certified by Krakow guild elders, and he paid a significant fee of one grivna to become a citizen. ${ }^{228}$ Soon afterward he married the widow of the deceased goldsmith Pawel Brenner. ${ }^{229}$ Nicholas must have had previous contact with the goldsmiths of Krakow, since they vouched for him. This is also proven by the fact that five years later he was elected as an elder of the goldsmiths' guild in Krakow. ${ }^{230} \mathrm{He}$ also held this prestigious position in later years $\left(1448,145^{\circ}\right.$,

226 The hierarchy of professions in the discussed group of crafts is similar to that in other towns of the region.

227 Jerzy Pietrusiński, Ztotnicy krakowscy, 594-599.

228 "Niclas Brenner de Paczke aurifaber h.i. Pro littera fideiusserunt seniores in brevi, dedit 1 mrc"; Books of Admissions, no. 5071, 161.

229 Jerzy Pietrusiński, Ztotnicy krakowscy, 594.

230 CONS. 428 , fol. 477. 
$1455,1458,1460$ and 1464).231 By the end of his life, his social position in the city had improved such that in 1462 he was elected to the municipal bench court. ${ }^{232}$ However, soon afterwards (in 1464) he fell ill and "lying on his mortal bed" (German tot bette), he gave his last will to the councillors who had come to his home. ${ }^{233}$ Using the security of half of his house, he confirmed a previously made bequest of 100 florins for his wife Barbara's dower. He donated his remaining property to his son Lorenzo. This brief bequest for his family was preceded by a detailed list of all the debts and receivables he had not managed to settle before his death, and which he left to his wife. This entry is an extremely interesting source of information both about the items he produced and about their intended recipients (including the nobleman John Kobiliński, the canon John Długosz, the voivode of Lublin Dobek, the voivode of Tarnów and the voivode of Krakow John Tęczyński). ${ }^{234}$ The presence of these figures testifies to the fact that this testator was one of the most valued goldsmiths not only in Krakow itself, but also in the whole region, and that his social and financial standing improved thanks to his exceptional professional skills. ${ }^{235}$

\subsection{Extremely Wealthy Testators}

The last and largest group of testators is made up of people counted among the richest and most influential spheres of Krakow's society. Representatives of this social group, often identified with the patrician class, ${ }^{236}$ are estimated to have comprised only a few percent of the city's overall population, but made as many as $36 \%$ of all preserved bequests of last will. Among the testators from this group, as many as 69 people were councillors on the Krakow municipal council $(45 \%)$, while the remaining male testators consisted of close relatives of councillors and rich aldermen. There were many merchants, including several who came to Krakow from other urban centers, sometimes very distant ones (such as Wilhelm Megirszheimer of Dinkelsbühl, John Raisser of Memmingen or Erhart Eigilwart of Augsburg). ${ }^{237}$ There were also Krakow's writers (Eustace the municipal notary, John Stolle of Głogów, Nicholas Newmeister

\footnotetext{
231 CONS. 428, fol. 511; CONS. 429, fol. 3, 114, 196, 264, 347 .

232 CONS. 429, fol. 119.

233 LT, fol. 83-84.

234 From spoons and plates to gold-plated belts and stripes to crosses, monstrances and chalices; LT, fol. 83-84.

235 The testator's death in the same year is evidenced by an entry in the council book in which the council gave Barbara's widows precedence before all his creditors to claim her dower from the estate of the deceased; SCAB. 8, fol. 187.

236 Roman Czaja, Grupy rządzace, $16-18$.

237 LT, fol. 135-136 (1482); SCAB. 8, fol. 598-599 (1476); CONS. 428, fol. 305 (1431).
} 
municipal deputy notary, and Christopher Rebentcz) ${ }^{238}$ whose wealth was equal to that of the richest citizens of Krakow. Among the factors proving their financial and social position, we can first mention the public functions they served on the municipal council and the municipal bench court, the bequests of dowers of considerable size (from 100 to 1350 grivna in the case of the richest of them, John Sweidniczer) and real estate located on prestigious plots near the city market square and in its vicinity. This group, due to its elite character, seems to be the most interconnected. Its characteristic feature was its participation in the culture of writing and wide reception of the practice of preserving a last will in writing. In many cases, wills made by a husband, his widow, his son or daughter have been preserved. ${ }^{239}$

Since the first wills appeared in Krakow, female testators have been found among those who made them. ${ }^{240}$ Although in the fourteenth century, testators were most often men - considered the rightful managers of property and goods - over time the number of women in this group grew and, as in other large urban centers, during the course of the two centuries under study here, constituted almost $30 \%$ of the total. ${ }^{241} \mathrm{Graph} 13^{242}$ shows how the number of female testators evolved in relation to the number of surviving wills.

238 LT, fol. 61-63 (1459); SCAB. 6, fol. 186, 187, 267; CONs. 429, fol. 27-28; KDM K, vol. 3, no. 439 (1439, 1442, 1451, 1454); SCAB. 6, fol. 186, 187, 267; CONS. 429, fol. 27-28; KDMK, vol. 3, no. 439 (1439, 1442, 1451, 1454; SCAB. 7, fol. 120 (1451); CONS. 429, fol. 693 (1481).

239 The well-known Morsztyn family is a good example of this, where the wills of Nicholas (1416 - SCAB. 4, fol. 143), John (1450 - CONS. 429, fol. 12), Stanisław (1450 - SCAB. 7 , fol. 86) and George ( 1500 - LT, fol. 161-164) have been preserved, as well as the wills of people linked to this family, e.g. councilorcou John Pitchen (LT, fol. 45), who was Stanisław's father-in-law, while his brother-in-law was the municipal notary Eustace (LT, fol. 61-63), or John Baumgart, a furrier (scAB. 6, fol. 215; CONs. 428, fol. 466).

240 KDMK, vol. 3, no. 368 (1302).

241 Similar proportions are found in medieval wills from other towns in the region, e.g. in Konstanz, in the period from 1368 to 1542 women made $31.7 \%$ of all the preserved wills, and in Bratislava $-38 \%$. However, these proportions tend to vary from 20 to more than $5 \circ \%$ depending on the town, the size of the preserved collections of wills and when they were written; cf. Paul Baur, Testament und Bürgerschaft, 61-68; Das Pressburger Protocollum Testamentorum 1410 (1427) - 1529, vol. 1, ed. Judit Majorossy, Katalin Szende (Fontes rerum Austriacarum, Österreichische Geschichtsquellen, 3, Fontes Iuris), (Wien: Bohlau Verlag), 3-10.

242 In Graph no. 6, in cases where the testator made more than one will, the date of the first will was taken into account. 


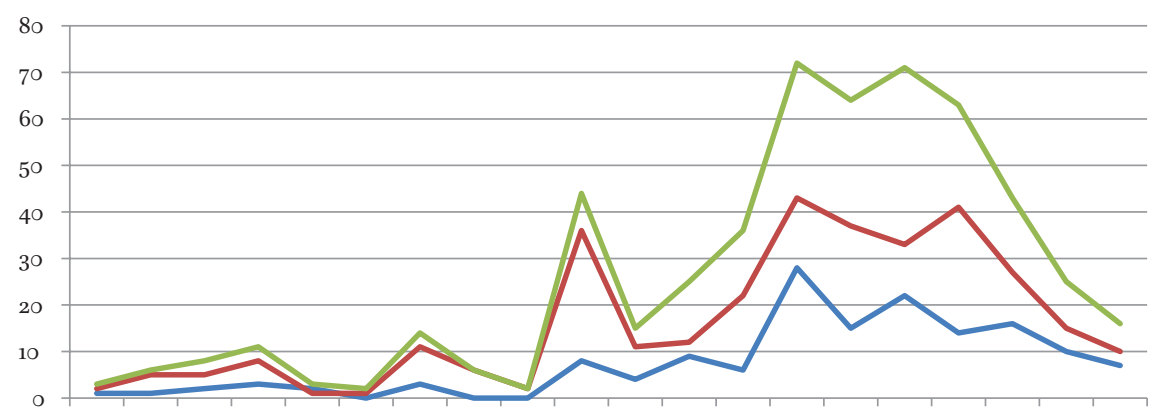

13101320133013401350136013701380139014001410142014301440145014601470148014901500

GRAPH 13 Number of women (blue) and men (red) among all Kraków testators (green) in the fourteenth and fifteenth centuries

This continuing dominance of male testators was natural in the medieval city, reflecting the culture and social dynamics of the day, according to which a married woman was subordinated to her husband, who managed their common property. Nevertheless, the comparison of the number of female and male testators from the period $1431-1470$ brings interesting results. These results are based on the source database of municipal bench and council books, both of which have survived for this period.

Table 5 shows that in the discussed period the percentage of women among all testators was over $50 \%$, and in some decades it even reached $65 \%$ and $67 \%$. It is a valuable testimony of the similar participation of (usually wealthy) men and women in the group of Krakow testators. On this basis, it can be concluded that in the period of relative dissemination of wills among Krakow burghers, gender seemed not to play a major role.

TABLE 5 The number of women and men among Krakow testators in the years 1431-1470

\begin{tabular}{lccc}
\hline Years & Women $(\mathrm{N})$ & Men $(\mathrm{N})$ & $\begin{array}{c}\text { Percent of women } \\
\text { among testators }\end{array}$ \\
\hline $1431-1440$ & 28 & 43 & $65 \%$ \\
$1441-1450$ & 15 & 37 & $41 \%$ \\
$1451-1460$ & 22 & 33 & $67 \%$ \\
$1461-1470$ & 14 & 41 & $34 \%$ \\
Total & 79 & $\mathbf{1 5 4}$ & $\mathbf{5 1 \%}$ \\
\hline
\end{tabular}




\section{Immigrant Testators}

\subsection{Immigration and the City's Population}

The image of large medieval cities that emerges from demographic research presents local metropolises as sick and weak organisms, 'consuming' large numbers of their inhabitants (due to high mortality rates) and thriving only thanks to a constant influx of new settlers from the countryside and smaller population centers. In the words of Jacek Wiesiołowski, "Medieval cities are considered to be giant places of extinction for their inhabitants, where the population cannot even sustain its own numbers, and where growth is totally dependent on high rates of migration."243 This phenomenon must also be taken into account when analysing the socio-occupational structure of Krakow. It is worth noting, however, that this refers to the population of the city as a whole, which itself was highly diverse in every respect, including in the fertility and mortality of its members. Studies of the development of pre-industrial cities point to a fundamental difference between two categories of inhabitants, permanent residents (i.e. burghers born in cities and immigrants who stayed in them permanently) and those who stayed there for a short time, for example because they were too poor to stay permanently. ${ }^{244}$ One theory derived from historical demographics proposes that it was the increase in mortality and lower fertility among immigrants that contributed to the negative birth rate in medieval cities. ${ }^{245}$ The essence of this distinction is the assumption that the living conditions and social roles available to newcomers made it difficult for them to start a family and attain a stable living situation, which in consequence contributed to lower birthrates and worse conditions for raising a child than among the city's permanent residents. It can be assumed, however, that it was mainly difficult living conditions, a problem experienced by the majority

\footnotetext{
243 Jerzy Wiesiołowski, Socjotopografia, 235 .

244 "The permanent residents, consisting of natives and some immigrants, lived out their lives in the city - married, had children and died - and enjoyed some measure of natural increase. The temporary immigrants who came to the cities, on the other hand, were preponderantly artisan journeymen and servants, and people of that status could seldom marry by the standards of early modern society. Given the high mortality conditions of the times, they contributed their due share of deaths to the vital registers of the cities, but as illegitimate fertility was substantially lower than legitimate, deaths outnumbered births by a very large amount"; Allan N. Sharlin, "Natural Decrease in Early Modern Cities. A Reconsideration," 'Past and Present' 79 (1978), 127, as in Jan de Vries, European Urbanization 1500-1800 (Cambridge (Mass.): Harvard University Press, 1984), 181.

Jan de Vries, European Urbanization, 185.
} 
of both newcomers and permanent residents of cities, that had the greatest impact on this phenomenon.

\subsection{Newcomers to the City}

The origin and family ties of Krakovian testators can be determined on the basis of three sources: a nickname indicating the place of origin of the person concerned; entries in the books of records of new citizens, in which the place of origin of a new citizen was sometimes noted; and finally, the contents of wills, in which the testator's parents or siblings living in other cities were sometimes mentioned, or bequests made (or foundations established) for hospitals and parish churches located in other communities. ${ }^{246}$

Nicknames containing place-names are most commonly found in wills made in the first half of the fourteenth century, when Krakow's elites had close ties with Wrocław and cities in Upper Silesia and Małopolska, a fact reflected in people's names. ${ }^{247}$ Among the testators were Krakow residents originally from Racibórz, ${ }^{248}$ Cieszyn, ${ }^{249}$ Żary, ${ }^{250}$ Głogów, ${ }^{251}$ Kluczbork, ${ }^{252}$ Olkusz $^{253}$ and Rożnów. ${ }^{254}$ Later, the practice of including one's hometown in one's name began to decline, especially among wealthy burghers, in favour of professional nicknames and a newly emerging form of family name - surnames. Despite this, in the fifteenth century, the origins of burghers who had come to Krakow from elsewhere is sometimes indicated by their surname, e.g. John Willusch from Zator, ${ }^{255}$ Nicholas Klausnicz a fustian maker from Nowy Torun ${ }^{256}$ or Gregory from Nowy Sacz. ${ }^{257}$

Of the 256 fifteenth-century male testators whose wills have survived to the present day, as many as 87 (i.e. $34 \%$ ) are found in the book of admissions to

246 Urszula Sowina, Kazimierz Pacuski, Testamenty mieszczan Krakowskich jako źródta do badań nad stronami rodzinnymi imigrantów w Krakowskiej elicie wtadzy (Przyktad Jana z Regut na Mazowszu), in Elita wtadzy miasta Krakowa i jej zwiazki z miastami Europy w średniowieczu i epoce nowożytnej (do połowy XVII wieku). Zbiór studiów, ed. Zdzisław Noga (Krakow: Antykwa, 2011), 433-445.

247 Jerzy Rajman, Mieszczanie z Górnego Ślaska w elicie wtadzy Krakowa w XIV w., in Elita wtadzy miasta Krakowa, 49-80.

248 Henryk of Racibórz; NKiRMK, no. 286 (1313).

249 Nicholas of Cieszyn; NKiRMK, no. 1189 (1336).

25 O Herman of Żary; NKiRMK, no. 119o, 1325 (1336).

251 Sydelman of Głogów; NKiRMK, no. 1352, 1397 (1340).

252 Gertrude, a widow of Nicholas from Kluczbork; NKiRMK, no. 1548 (1345).

253 Frederick of Olkusz; NKiRMK, no. 106 (1310).

254 Peczold of Rożnów; NKiRMK, no. 34 (1306).

255 CONS. 427 , fol. 46 (1394).

256 LT, fol. 94 (1468).

257 SСAB. 8, fol. 29 (1460). 
municipal law (Libri iuris civilis) in Krakow, i.e. among the burghers obtaining city citizenship. ${ }^{258}$ Another 74 testators were found to have acted (sometimes several times) as guarantors of persons being granted citizenship in Krakow, which indicates that they had already done so. On the basis of this data it can be concluded that a significant number of testators, at least one third of them, were immigrants who had arrived in Krakow from elsewhere, and who then, following a variety of different paths, merged into the city's urban society. What is more, among the group of 89 burghers, as many as 17 of them served as Krakow councillors. This proves that the city's elites were quite open to 'foreigners' who possessed significant economic and cultural capital. Social capital, in turn, was usually acquired by newcomers by marrying Krakow citizens belonging to this elite. 259

Although books of records of new citizens are a very valuable source for research on the medieval society of Krakow, they inform us only about a certain segment of the people who came to the city. While the purchase of a house was not officially required to obtain citizenship in Krakow, and sometimes even members of the poor were allowed to receive such a status (in such cases, the councillors granted them exemptions or reductions of fees) $)^{260}$ only a small percentage of all immigrants to Krakow were interested in obtaining citizenship in the city. The greatest interest was expressed by those who would benefit directly from such a change. These were most often merchants and craftsmen, for whom citizenship in the city would give them the right to join a guild or be granted trade privileges made to Krakovians. ${ }^{261}$ It is therefore not surprising that the ownership status of testators who had the right to obtain citizenship reflected basic tendencies observed within the group as a whole: 39 newcomers $(45 \%)$ can be described as very rich, fifteen $(17 \%)$ as rich, $26(30 \%)$ as welloff and only seven (8\%) as poor. Again, the rich and very rich - representatives of the upper class - constitute the vast majority of all 87 testators considered

\footnotetext{
258 In some cases, there are some doubts as to whether the note in the Book of Admissions relates to a given testator or just a person with a similar name and nickname. This problem mainly concerns townspeople with popular names, such as John, Peter, Matthias or Nicholas, with nicknames indicating their occupation.

259 The concept of economic, cultural and social (and symbolic) capital was developed by Pierre Bourdieu; cf. idem, The Forms of Social Capital.

260 "In fourteenth- and fifteenth-century Krakow (1392-1485), many people, i.e. $5^{8}$ people, defined as servants (servitor, famulus) became citizens of the city, as well as four janitors in the years 1401-1503, and fourteen people generally referred to as laborator in the same period"; Stanisław Gierszewski, Obywatele miast Polski przedrozbiorowej (Warszawa: Państwowe Wydawn. Naukowe, 1973), 38. Neophytes, Jews, Lithuanians and Ruthenians were usually also exempted from the fees; cf. Books of Admissions, XVIII.

Stanisław Gierszewski, Obywatele miast, 36 .
} 
here. Similar conclusions can be drawn from an analysis of the fees paid for citizenship. The tax rate charged depended on one's wealth and, as mentioned above, ranged from nine to 60 groszy. Among the 87 testators who obtained Krakow citizenship, in 27 cases we know the amount of their fees. These were in the range of sixteen to 72 groszy, ${ }^{262}$ with an arithmetic mean of 37.5 groszy, and a median sum of 36 groszy.

In nearly every case, the decision to emigrate meant a radical change in one's living situation. Newcomers to Krakow had to work hard to build up their social position from scratch, unless a foundation had been laid earlier by previously existing trade or family contacts (which appears to have been the case for at least some of those who came to Krakow from the surrounding area and for merchants engaged in long-distance trade). For many immigrants, the easiest way to assimilate and make a career in their new environment was to get married. While married burghers such as John Raczko de Brunen brought their wives to Krakow from their hometowns, ${ }^{263}$ poorer immigrants who lacked the support of relatives, friends or co-workers in the city had a harder time finding a marriage partner than the cives who were born in the city. ${ }^{264}$ This problem affected both men and women alike. However, it can be assumed that the majority of newcomers were men who were expected to be more mobile than women in a traditional society such as this one. One of the most reliable ways to find a place within the city's social structure was to marry into a Krakovian burgher family. However, the marriage market must have been characterised by a relatively higher demand than supply of potential 'good wives.'265 And, as Rossiaud points out, "Money undoubtedly facilitated integration, but it was not able to solve all one's problems. Even if he possessed the same level of property as a local burgher, the immigrant did not have the same network of contacts or the same opportunities for employment, admission to a guild, or participation in public life as the native-born, who put before him all sorts of legal and practical obstacles." ${ }^{266}$ Urban history studies confirm that these two

262 It was not until 1436 that the practice of recording the amounts paid by citizens was established; Books of Admissions, XIV-XV.

263 "Johannes Raczko de Brunen i.h. Matis Pasko et Nickel Edrer pro littera et eius uxore huc in duodecim septimanis sub pena X mrc et perdicione iuris civilis., ballistam dedit"; Books of Admissions, no. 5578 (1445).

264 Jan de Vries, European Urbanization, 186-197.

265 This phenomenon seems to have been occurring despite estimates by German historians indicating a larger share of women than men in Hanseatic cities; Henryk Samsonowicz, "Zagadnienia demografii historycznej w rejonie Hanzy w XV-XVI w.," Zapiski Historyczne 28 , no. 4, 523-554.

266 Jacques Rossiaud, Mieszczanin i życie w mieście, 187 (J. Rossiaud, Le Citadin). 
tendencies often coexisted; protectionist policies favouring the sons of local citizens were bolstered by legal and financial obstacles placed before immigrants that could be easier or harder to overcome, depending on the city's need for labour. ${ }^{267}$ Rich and well-off immigrant-testators who through their resourcefulness, wealth and family influence, found their future wives in Krakow, gradually blended into the city's fabric after their marriage. Some married rich widows, such as Paul Newburger, the future Krakow alderman and councillor, who took Krakow citizenship after marrying the widow of councillor Tilman de Bruch. ${ }^{268} \mathrm{~A}$. Bartoszewicz gives the following example: "After his marriage to Ursula Hoze, the career of Eustace, deputy notary of Krakow from 1451, began almost immediately: in 1454 he became the head of the municipal chancellery, and obtained city citizenship; ${ }^{269}$ he then entered the circle of Krakow patricians, began trading in lead from Olkusz, and accumulated considerable wealth."270 The social successes of other famous Krakow litterati were also often associated with marriages to wealthy widows. ${ }^{271}$

The time immigrants spent in the city before they wrote their wills also testifies to how rooted they had become in the city. The differences in this respect are, of course, enormous and depend on many individual factors, ranging from whether the wills were made a few years before obtaining citizenship or made a few decades later. However, both the arithmetic mean and the median in both cases amount to as much as a 21-year difference between acquiring citizenship and the writing of a will, ${ }^{272}$ which indicates both the old age of a large portion of the testators and the long years they spent in Krakow.

Despite the testators having lived in Krakow for many years, in many wills one can find traces of old family ties, whether professional or purely emotional, connecting testators with their former home towns. In many cases, siblings who remained in the family's hometown were included in the will. For example, the wealthy burgher John Lode, who became a citizen of Krakow in 1446, paying a fee of as much as one grivna to obtain citizenship, ${ }^{273}$ bequeathed in 1456 ten

\footnotetext{
267 Stanisław Gierszewski, Obywatele miast, 48.

268 "Paulus Newburger maritus relicte Tilmanni de Bruch h.i. Pro littera portanda ad festum Pasce fideiussit Tawbinfelt et Sweydniczbir"; Books of Admissions, 136.

269 The municipal notary Eustace, when accepting the municipal charter of Krakow in 1455, was exempted from such a fee.; cf. "Eustachius notarius civitatis i.h. Prius litteram portabit,nichil dedit”; Books of admissions, no. 6255 .

270 Agnieszka Bartoszewicz, Piśmienność (2012), 183.

271 Ibidem.

272 In the case of testators who left several versions of their last will, only the date of the first one was considered.

Books of Admissions, no. 5670 .
} 
florins to his brother Nicholas Lode from the Małopolska town of Pilzen, which he was to receive when he grew up. ${ }^{274} \mathrm{John}$ Baumgart, who became a citizen of Krakow in $1412,{ }^{275}$ bequeathed in his will of 1440 part of his estate to his sister in Dresden. ${ }^{276}$ The wealthy Ambrose Czockeling did the same, and in 1451 gave his sister and her children from Wrocław 50 florins. ${ }^{277}$

In his will, Paul Ber, a long-time alderman and later Krakow councillor, wrote very clearly about his ties with his family in Głogów. This burgher, whose 'good fortune' in the process of obtaining citizenship was guaranteed by the alderman Bartholomew Graudencz, ${ }^{278}$ bequeathed in his will of 1467 to his sister Anna part of the money due to him from the family house in Głogów, where this Anna still lived. ${ }^{279}$ Moreover, he gave the Głogów local parish Church of St. Nicholas a chasuble and a large new missal, "so that these two things could be used every day to remember and comfort the souls of my parents and relatives whose bodies lay in rest there." ${ }^{280}$ This clearly testifies to the sense of community he felt with both his family and his former parish church.

Signs that testators maintained attachments to religious communities to which they once belonged are present in many other cases, as well. Although the numerous churches in Krakow are usually the primary beneficiaries in their last wills, burghers also made donations to former parish churches and hospitals in their hometowns. This was the case with John Sweidniczer, who obtained Krakow citizenship in 1417. He sold his house in Świdnica in order to establish a fund for a new altar with a substantial annuity (twelve to fourteen grivna) in the local parish church. He also decided to make a donation to the monastery Church of the Holy Cross in Świdnica (belonging to the Knights of the Cross with the Red Star) and the Franciscan Church of the Blessed Virgin Mary in Torun, where his brother Jacob and perhaps other relatives lived. ${ }^{281}$

Krakovian testators from Wrocław also took into consideration in their wills places of worship with which they were formerly associated. In 1439,

\footnotetext{
274 LT, fol. 37.

275 Books of Admissions, no. 2335.

276 " [...] meynir swestir Barbara dy czu Drezen in der Stat wonet und ir elicher man ist genant Michel Richter"; sCAB. 6, fol. 215.

277 LT, fol. 26.

278 Books of Admissions, no. 569 o.

279 SCAB. 8, fol. 270-271.

280 "Ouch bescheyde ich ken Grosglogow yn dy pharkirche zu sinte Niclos eyne kamiche kasel dy beste undir czween dy ich gereyt habe und das grosse newe Missale das man dy czwestucke alle tage notczen sal zu eyme gedechtnisse und troste meyner elden und frunden zelen, der leythnam derselbist rasten"; SСAв. 8, fol. 270-271. 
Margaret, widow of alderman Nicholas Slepkogil, bequeathed twelve and a half grivna to Wrocław councillors for an altar in the Corpus Christi chapel in the parish church at the Wrocław market square. ${ }^{282}$ John Kletner, a rich burgher from Wrocław who later served as a alderman and councillor in Krakow and who obtained Krakow citizenship in 1448 , bequeathed in his will in 1460 the handsome sum of 500 grivna to his sister Barbara from Wrocław, and also left detailed instructions for making pious bequests. He left 200 florins in the 'trusted hands' of Henry Hemmerdeye in Wrocław, which was to be used to support charitable work at St. Barbara's Hospital, or another beneficiary of Henry's choice. ${ }^{283}$ Another 400 florins owed to him were to be donated to fund construction of St. Catherine's Church in Wrocław, and especially - in accordance with the testator's wishes - the construction of its nave.

The rich stallholder Martin Streicher, who came from Brzeg, and John Schultis (also known as Thob Johan), one of the richest patricians in Krakow, both made generous bequests. Streicher bequeathed an annuity of three grivna to the local hospital in Brzeg. ${ }^{284}$ In the first version of his will, made in 1443, John Schultis used the huge sum of 66 grivna (collected in rent in Wrocław) to make various bequests: he bequeathed ten grivna each to St. Anthony's Church in Brzeg, to his local parish church and to the parson's household in Brzeg, and used the remaining 36 grivna and 32 groszy in rent for the foundation of a perpetual sung mass at one of the altars for the salvation of his soul. ${ }^{285}$ In a second will, made eight years later, he repeated his previously made pious bequests. ${ }^{286}$

Some testators also mentioned their native cities because they still owned property in them, presumably inherited from their immediate families. This was true in the case of John Reinczka, who came from Olkusz. Four years after he obtained Krakow citizenship in $1458,{ }^{287}$ following an illness he made a will in which he stated that his wife could live in their house in Olkusz until her death (if she remained a widow). ${ }^{288} \mathrm{~A}$ similar provision was included in the last will and testament of Stanisław Czolek in 1479. He granted to his brother Nicholas Koth possession for life of his property in Zator, but after Nicholas's death, it was to be given to Stanisław's heirs. ${ }^{289}$ The origin of Nicholas, the

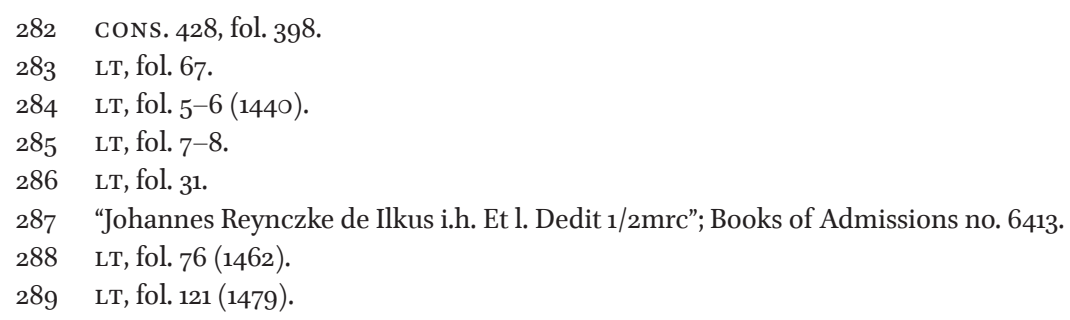


owner of the Jewish bathhouse, who obtained citizenship in Krakow in 1446, is suggested by his ownership of real estate in the town of Robczyce. The mention in his will of 1453 of people from nearby Pilzno (Nicholas Jangueski and Matthias łaziebnik) indicates that after leaving Robczyce, Nicholas could have lived for some time in a larger city, and only at the end of his life moved to the capital, Krakow. ${ }^{290}$

Often, however, a testator and his closest relatives were also able to leave their hometown in search of opportunity both closer and farther away. A good example of this is the will of John Tile, who mentioned relatives (frunde) living in various places: Dominik Czop with his son John from Sandomierz (Czudmir), a relative named Merlin, the daughter of Crotinpfulis from Racibórz (Rathibor), and the daughter of Andrew Ruswormos from Ząbkowice Śląskie (Frankinsteyn). ${ }^{291}$

\subsection{Cultural Capital of Newcomers}

On the basis of the examples given above, it can be seen that the strong ties connecting Krakow and Silesia in the first half of the fourteenth century continued to be maintained later. Świdnica, Brzeg, Głogów and - above all - Wrocław were all cities from which a significant part of Krakow's rich burghers and even its power elites were recruited. These wealthy and influential burghers were also most interested in maintaining ties with their former towns, where their property, family members and former parish churches, as well as the remains of their ancestors, still remained. However, there is also no shortage among the testators of influential Krakow burghers coming from other, often quite distant population centres, such as John Raisser from Bavarian Memmingen, ${ }^{292}$ Erhart Eigilwart from Augsburg, ${ }^{293}$ or Gotfrid Fattinante from Genoa. ${ }^{294}$

Behind the rapid social advancement of wealthy immigrants in large cities were undoubtedly previously established business contacts and considerable wealth. However, we cannot ignore a less obvious factor: their cultural capital. This meant knowing what behaviour was 'proper' and how to behave in particular places and circumstances, and how to talk to different people. Norbert Elias' research on the phenomenon of the 'civilisation process' showed how the social norms for a good education were shaped in the Middle Ages, and in

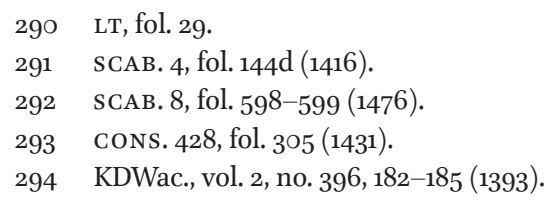


subsequent centuries. ${ }^{295}$ Legal principles for proper dress (e.g. anti-sumptuary laws, ${ }^{296}$ and bans on walking around the city without a head-covering, as laid down in the municipal statutes), ${ }^{297}$ and behaviour in the town hall, at a fraternity meeting or at the church, ${ }^{298}$ as well as at the table, ${ }^{299}$ were resources of cultural knowledge, without which it was impossible to function in a group. While first generation immigrants from villages and small towns who came to Krakow had to assimilate many of these rules and certainly would not have felt comfortable, the more sophisticated citizens of large German or Italian cities who came to Krakow could use their cultural capital in their relations with the citizens of Krakow and in their efforts to penetrate its elite social circles. This was probably the case with Italian newcomers, who initially took lucrative positions as royal miners, served the king, and engaged in large amounts of international trade, ${ }^{300}$ as well as the Rhineland Germans, who from the midfifteenth century eagerly came to Krakow. The Krakow councillor and secretary of King Sigismund I, Louis Decius, proudly describes the process by which his compatriots from Wissemburg come to Krakow: "Reinfred arrives in Krakow, and having found financial success and respect here greater than in his former homeland, he brings in his relatives and friends." ${ }^{301}$ Cultural capital was at least as important as material capital in making immigrants valuable partners. The same rules seemed to apply elsewhere. Antoni Gąsiorowski describes a similar situation in Poznan, discussing the successful career and rapid promotion of a newcomer to the city, George Bock, as follows:

$\mathrm{Bo}[\mathrm{c}] \mathrm{k}$ with his merchant and banker individuality, shaped in the conditions of a big city like fifteenth-century Gdańsk, surpassed all his partners in Poznan, both in terms of his significance as a merchant and his influence with the municipal government. The history of his career, however,

\footnotetext{
295 Norbert Elias, Przemiany obyczajów w cywilizacji Zachodu, trans. Tadeusz Zabłudowski (Warszawa: Państwowy Instytut Wydawniczy, 1980).

296 KDM K, vol. 1, no. 21; KDM K, vol. 2, no. 259, 334, 352; Najstarszy zbiór przywilejów i wilkierzy miasta Krakowa, vol. 2, ed. Stanisław Estreicher, no. 12.

297 KDMK, vol. 2, no. 334.

298 Ibidem.

299 Obyczaje w Polsce. Od średniowiecza do czasów wspótczesnych, ed. Andrzej Chwalba (Warszawa: Państwowe Wydawnictwo Naukowe, 2004), 6o-63.

3 oo Stanisław Kutrzeba, Jan Ptaśnik, "Dzieje handlu i kupiectwa krakowskiego," Rocznik Krakowski 14, 1910, 96-108.

301 Ibidem, 73 .
} 
shows how easy it was to make a career in a city like Poznan for an important newcomer who had come from a big city center. ${ }^{302}$

It seems that, soon after their arrival in Krakow, less wealthy burgher-testators tended to engage in the crafts, and not trade, and often lost contact with their hometowns. However, knowing that their relatives still remained in their hometowns, many had fearful thoughts about how their relatives' rights of inheritance might compromise the financial security of their immediate family. It can also be assumed that most of these immigrants came from nearby cities, towns and even villages - from these places wealthy peasant youths, the sons of members of the rural elite, came to Krakow. ${ }^{303}$ It can also be assumed with a high probability that Krakow attracted moderately well-to-do peasants and the rural poor. As a large city - with a market, hospitals and almshouses it offered greater chances of earning money and food than could have been expected in the countryside, even in periods of food shortages. However, these sorts of immigrants did not usually try to obtain Krakow citizenship, to which they probably did not even aspire. It is even less likely that they would write their wills in Krakow, relying instead on the traditional rules of inheritance of property, or giving only oral instructions concerning their assets. ${ }^{304}$

Jacek Wiesiołowski's estimates, which used 1.5 children per burgher family as the fertility rate indicator in medieval Poznan, brought him to the conclusion that the demographic growth of the city was possible only with a significant influx of immigrants, who constituted $60 \%$ of the city's population in each generation. ${ }^{305}$ Even if the number of children in the average Krakovian burgher family was higher and the percentage of immigrants living there slightly lower than in Poznan, the population of medieval Krakow must still have consisted to a large extent of immigrants, constituting a colourful

302 AntoniGąsiorowski, “Ludnośćnapływowawstrukturzespołecznejpóźnośredniowiecznego Poznania," Studia i Materiaty do Dziejów Wielkopolski i Pomorza, 11, no. 2(22) (1975), 11-25.

303 Ibidem.

304 Studies on migration from rural to urban areas in the Old Polish period indicate that the rule that "the larger the city, the smaller the number of people of rural origin had a chance to enter the ranks of citizens. Conversely, in large cities, peasants were more likely to be accepted as labourers than in small towns, while the urban poor were more likely to be accepted as 'loose' people. After all, the struggle for the labour force between the feudal lords and big cities continued. There is no available research for medieval Krakow concerning the size of peasant immigration and what part of it was granted citizenship, but it was probably proportionately smaller than in fifteenth-century Poznan, where about 1/3 of all people granted town rights originated from rural areas"; Stanisław Gierszewski, Obywatele miast, 111; Antoni Gąsiorowski, Ludność naptywowa, 13-15.

Jacek Wiesiołowski, Socjotopografia, 236. 
mosaic of people of varying levels of wealth, engaged in many different professions, and representing a variety of cultural groupings that had different places within the life of the city. Only $10 \%$ of those who obtained citizenship in Poznan in the years 1443-1445 left any trace in other sources, which means that "the vast majority of these burghers did not make a career in the city, did not conduct any property transactions (which would have been reflected in the completely preserved resignation books), [and] did not attain a municipal office such as the guild seniority, not to mention a place on the bench court or the municipal council." ${ }^{306}$ Martin Nodl, who studied the society of medieval Stríb at the turn of the fourteenth and fifteenth centuries, stated that only one third of immigrants settled in the town permanently. Only those who stayed in the city for more than ten years had a chance to gain higher material status and move to a higher tax group. ${ }^{307}$ This significant mobility among the poorest inhabitants of the city is confirmed by the changes in the number of taxpayers in Kazimierz in the years $1385^{-1387}$ : "The set of property owners is relatively stable, and the whole burden of the changes falls mainly on the poorer strata, especially those who have no possessions, who respond quickly to a changing economic situation or a downturn, and during such times either leave the city or are drawn to it."308

\section{Determinants of Testators' Social Position}

\subsection{Economic Capital}

From what we know about the composition of the Krakow municipal council, a large amount of economic capital was a conditio sine qua non for applying for a seat on the council. This condition was fulfilled by all of the 66 councillors whose wills have survived in municipal books to the present day (which is about $21 \%$ of all 325 known councillors up to the end of the fifteenth century).

Graph 14 reveals certain patterns in the dower bequests found in councillors' wills, indicating to some extent the distribution of wealth among them. Three main thresholds can be distinguished: up to 200 grivna - nine bequests (most of them before the 1430s); from 200 to 450 grivna - thirteen bequests (from the 1430 s to the end of the century) and from 450 to 1350 grivna - four

\footnotetext{
306 Antoni Gąsiorowski, Ludność naptywowa, 18.

307 Ewa Wółkiewicz, Migracje do miast średniowiecznych w świetle ksiag przyjęć do prawa miejskiego, in Miasto czyni wolnym. 79 o lat lokacji Opola (ok. 1217-2007), ed. Anna PobógLenartowicz (Opole: Polskie Towarzystwo Historyczne, 2008), 52.

308 Jacek Wiesiołowski, Stratyfikacja mieszczaństwa polskiego, 278.
} 


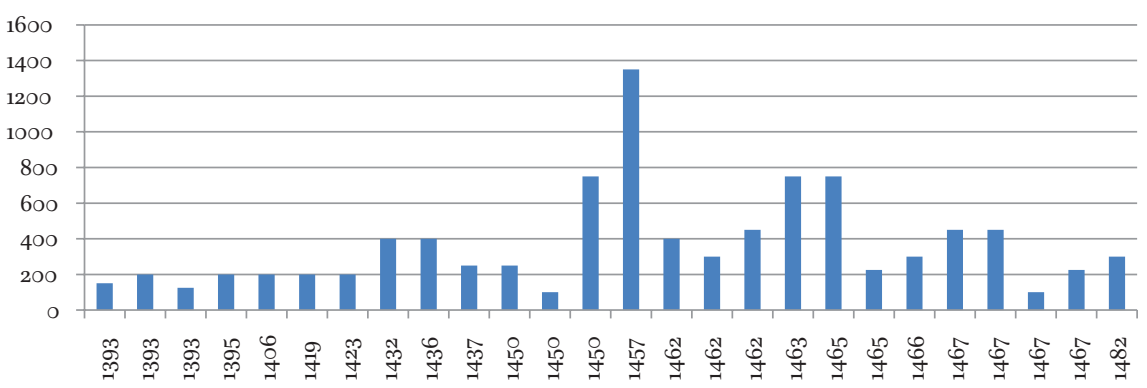

GRAPH 14 The amount bequeathed in dowers in the wills of Krakow's councillors

bequests. It should be noted, however, that the table above includes the largest dowers present in the wills made by each individual. When he made his first will before councillors in 1439, councillor John Sweidniczer left his wife Anna 600 grivna, as well as 200 grivna for the dower promised to her before their wedding (which probably took place around 1417, when he obtained city citizenship) and an additional 400 grivna as an expansion of the dower. ${ }^{309}$ In 1447, he revoked the will, 310 and in 1456 provided a dower for his second wife Agnes, giving her 6oo florins, which was to be added to the 1000 florins that she had brought into the marriage (she had been a widow with her own children). ${ }^{311}$ Later that year, John, stricken with illness, called for councillors and once again revoked all his previous wills, this time leaving his wife Agnes 1800 florins for her dower as well as the money she had brought into the marriage. ${ }^{312}$ This is also the case with another very wealthy councillor, John Teschner, who in his testament of 1453 revoked all the bequests and donations he had previously made to his wife and gave her a dower of 8 oo florins "for her faithful service" and allowed her to live in his corner house for the rest of her life. ${ }^{313}$ However, nine years later, in 1462, he testified before councillors and in the presence of his brother-in-law, John Turzon of Levoča:

[I]n accordance with the call of the holy Christian Church, he went with his wife Martha to her home city of Levoča, and there, before councillors

\footnotetext{
309 CONS. 428, fol. 402.

310 Ibidem.

311 CONS. 429 , fol. 137 .

312 This will is dated 1457 in Liber Testamentorum, but other provisions related to the execution of his will indicate that Sweidniczer died in 1456; LT, fol. 39-43; CONS. 429, fol. 16o, $163,167,172,173,174,176,178,18$ o, 192, 194,195, 210, 212, 213, 218, 221, 229, 246, 247, 249, 261$262,274,279,310,328,338$.

CONS. 429 , fol. 71 .
} 
in that city, bequeathed to her a dower of 600 florins; today, in presenting this letter, he was informing [the councillors] that he was adding an additional 400 florins to the dower. Therefore, after his death she was to receive 1000 florins secured by all his assets, with no objections permitted from his relatives. ${ }^{314}$

As the examples above show, the amount of the dower varied depending on when it was made, the financial status of the testator, the social and financial position of the wife's family, and whether or not the testator had remarried after the death of his previous wife. However, it is also worth noting that testators and notaries writing down their wills usually tried to adhere to the principle of indicating both the amount of the dower promised before the marriage and the amount that had been added to it (in Polish przywianek).

On the other hand, among the testators, we find many burghers whose large dower bequests and considerable wealth were still not enough to qualify them for a seat on the municipal council. In Graph 15, which lists the amounts of the dowers bequeathed by wealthiest testators, we can see that the group of very rich burghers included, apart from the aforementioned 26 councillors, 32 other Krakovian burghers. Among the rich burghers (corresponding to the lower upper-income group in Jacek Wiesiołowski's classification) we find another $3^{2}$ citizens of Krakow who made dower bequests of between 6o and 100 grivna. These figures do not provide a basis for estimating the total size of these groups, nor for assessing what part of them were Krakow councillors, but they do point to the existence of a relatively broad and varied group of very wealthy Krakovian burghers who were never officials in the municipal government. To investigate further who they were and how their wealth compared to councillors', the sizes of their dower bequests have been compared with those made by councillors.

In most cases, the dowers contained in the wills of non-councillors are similar in size to those of Krakow councillors. The vast majority of non-councillors (27 individuals) bequeathed between 150 and 300 grivna, while only five of them left their wives more than 300 grivna (compared to ten councillors who made such provisions). As a result, there is a smaller range than in the councillors' group, yielding a mean value of 239 grivna, and a median value of 200 grivna. While in the case of the non-councillor burghers we are dealing with a fairly homogeneous group, in most cases they were no less wealthy than the group of councillors.

314 CONS. 429, fol. 338. 


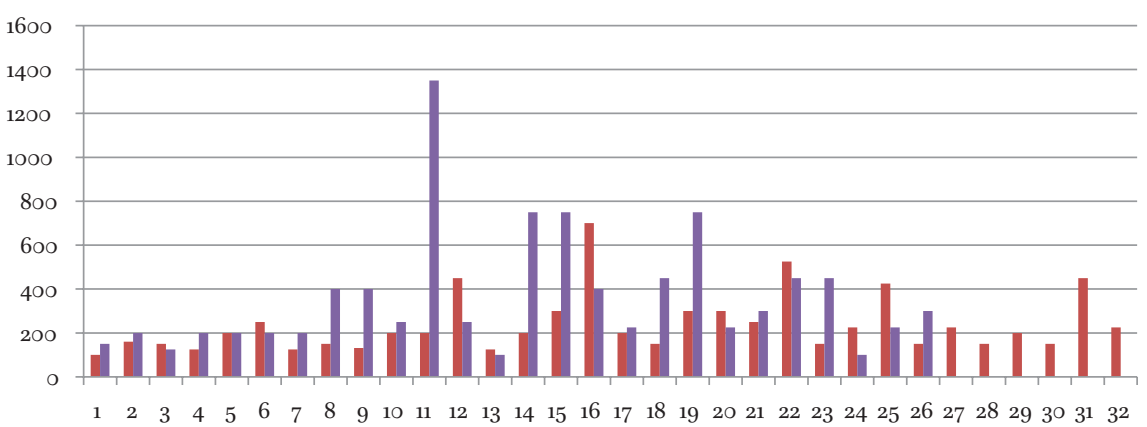

GRAPH 15 Amounts of dowers contained in the wills made by Krakówcouncillors and the wealthiest non-councillor Krakow's citizens

The most prominent people in the non-councillor group are the five individuals whose dowers amounted to more than 300 grivna. In order to better illustrate their social position, references to them contained in municipal books are presented below:

1. Erhart Eigilwart, of Augsburg, who served on the bench court in 1418 and 1421, was a merchant who had ties to Wrocław and the prosecutor Conrad Goczcze of Augsburg. In 1422 he was entered into the municipal book as elder of stallholder guild (senior institorum). The preserved will was made by Eigilwart while ill in $1431 .{ }^{315}$

2. John Schultis, alias Thob Johan, who probably came from Brzeg, was a alderman in Krakow (in 1419, 1421, 1424, 1426 and 1428) and one of the richest merchants in the city, trading with Košice, Lviv and Wrocław. In 1406, he was among those few who paid the special royal tax for the armed expedition to Lithuania (he paid the relatively small amount of four grivna). ${ }^{316}$ In 1421, he was mentioned as a person who held the keys and padlocks to the chains that closed off the ends of the streets leading to the market, ${ }^{317}$ which means that he owned a house on a prestigious corner plot by the market. In 1422 he was elected the commander of the tower above the New Gate (in Latin Nova Valva) on the city walls. ${ }^{318} \mathrm{He}$ founded his own chapel and altar in St. Mary's Church. After his death, he

315 CONS. 428, fol. 305. Erhart Eigilwart (Egilbart) is mentioned in the book of records of a new citizens only once, as a guarantor for Jost Reborr in 1417; cf. Books of Admissions, no. 3049 .

316 CONS. 427 , fol. 270.

317 CONS. 428 , fol. 165 .

318 CONS. 428 , fol. 188 . 
was entered into the Book of the Dead of the Brotherhood of the Blessed Virgin Mary (as was his son John, who also left a will). ${ }^{319}$

3. Sylwester Sweidniczer, brother of John Sweidniczer, was one of the richest fifteenth-century Krakovian burghers. He obtained Krakow citizenship in 1439, after paying an entrance fee of one grivna, backed by his father-in-law Nicholas Scholwicz, a Krakow councillor. In 1451, after the death of Scholwicz, and his wife's receipt of an inheritance from her father, he secured a dower of 200 grivna for her. In 1452, when he was ill, he raised the amount of dower 700 florins. He owned a house at the market square. He was a cloth merchant. ${ }^{320}$

4. Eustace Statschreiber became Krakow deputy notary in 1451, but obtained citizenship only in 1454 and was then appointed the municipal notary. He traded in lead from Olkusz. He married Ursula, daughter of councillor John Hoze and the widow of Nicholas Schirtel. In 1453, in a mutual bequest, she gave him all the rights to the inheritance from her parents and sisters, while he secured this inheritance with his own estate and left her a dower as well. ${ }^{321}$ The will, written on his sickbed, was entered in the Liber Testamentorum in $1459 .{ }^{322}$

5. Peter Schepcz was a Krakow alderman (1481-1483) and son-in-law of Peter Pelczer (son-in-law of John Sweidniczer). ${ }^{323}$ In 1477, after the death of his father-in-law, his wife Hedwig gave her inheritance from her father to him. ${ }^{324}$ In 1482 , he made his own will, which he later confirmed before the bench court. In it, he included many carefully thought out pious bequests and divided his property between his daughter Dorothy and second wife, also named Dorothy, who was pregnant at the time. ${ }^{325} \mathrm{He}$

319 Józef Mitkowski, "Księga zmarłych bractwa kościoła Panny Marii w Krakowie (wiek XIVXVIII)," Studia Historyczne 11, no. 1 (1968), 85.

320 LT, fol. 28-29; Books of Admissions, 4995, 158; CONS. 429, fol. 35; SCAB. 6, fol. 303 .

321 SCAB. 7 , fol. 165,173 .

322 LT, fol. 61-63; cf. Bożena Wyrozumska, Kancelaria, 123; Agnieszka Bartoszewicz, Piśmienność (2012), 164, 183.

323 Bequest of a dower for Sweidniczer's daughter in 1443; SCAB. 6, fol. 293.

324 CONs. 429, fol. 585 .

325 A total of 66 florins: "I give 10 florins to the hospital for food for the poor; five florins to poor pupils for food; five florins to St. Valentine for food for the poor; 10 florins to St. Hedwig for food for the poor; 10 florins to St. Bernard for food for the monks; four florins to St. Leonard for food for the poor; two florins to the poor lunatics (torichten) for food; two florins to the imprisoned for food (gefengene in den stogk); two florins to St. Francis for Gregorian masses, for food; two florins to St. Trinity for Gregorian masses (for the salvation of the soul); two florins to the monks at St. Catherine for Gregorian masses; one florin 
owned the following properties in Krakow: a house at the market square, another house on St. Florian Street, and half a pharmacy. In his will he also made many pious bequests. He entrusted guardians to settle all his liabilities with the help of his accounting book and other notes. After his death, in order to validate his will, it was entered into the Liber Testamentorum, and his son, also called Peter Schepcz, confirmed its validity. ${ }^{326}$

Of these five Krakovian burghers, all with considerable estates, none were councillors. Three were aldermen (two of them only held the position for $2-3$ years), one was a municipal notary, and one was a brother of the very influential councillor John Sweidniczer. Peter Schepcz and Eustace the notary had connections with the families of councillors. But the most notable thing they had in common was the fact that they were all engaged in long-distance trade. Although they were not members of the municipal council, and did not belong to the Krakow elite, they were nonetheless part of the same social circle. It is possible that what prevented them from becoming councillors was the fact that they all appear to have come from outside of Krakow: Apart from Peter Schepcz, whose origin is unknown, the remaining four testators came from other cities and had to build their social capital from scratch when they relocated to Krakow.

The data presented above suggests that the city's ruling elite was significantly diversified in terms of wealth and individual prestige. The council, like the entire town population, had its own structure. The council was led by a few of the most influential individuals, notable for their wealth, business transactions and connections. The remaining councillors comprised a less diversified group, similar in wealth to other prosperous Krakow residents. This confirms the assumption that wealth (economic capital), although an important factor determining the social position of testators, was certainly not synonymous with a place on the council. It seems fair to assume that this kind of social advancement was determined by other factors, which, in the language of Pierre Bourdieu, can be described as cultural, social and symbolic capital. ${ }^{327}$

\subsection{Cultural Capital-Education}

In late medieval Krakow, the university elite had long been legally and socially distinct from Krakow's burghers. Although members of the Studium Generale

to the monks of the monastery of the Blessed Virgin Mary for Gregorian masses; one florin to the monks at St. Mark for Gregorian masses; 10 florins for the altar of the Virgin Mary (der tofele der Juncfraw Marien)"; LT, fol. 137-140.

326 Ibidem.

327 Pierre Bourdieu, The Forms of Social Capital, 46-58. 
enjoyed great authority, because they were subject to church law they were considered to be more like clergymen than townspeople. Despite their mutual connections with town citizens, like priests and monks they were not of the same community as the city's other citizens, at least not from the perspective of the authorities, because they were not subject to their jurisdiction and were not bound by the same legal norms as other inhabitants. Over the course of the late fifteenth century, however, due to the university's close ties with the city, the growing number of influential burghers' sons among the student population, and changing cultural trends - often associated with the Renaissance, broadly defined - the representatives of academia began to play an increasingly important role within the upper strata of civil society. ${ }^{328}$ As early as in 1393, Gotfrid Fattinante from Genoa chose the Krakow bishop, a doctor of Canon and Roman laws Peter Wysz from Radolin, as one of the executors of his will. ${ }^{329}$ Similarly, in 1439, as one of the executors of his will John Sweidniczer appointed Doctor of Canon law Nicholas from Brzeg. ${ }^{330}$ In 1484, the validity of Francis Gliwicz's will was confirmed by the Krakow canon and John Starzechowski, a doctor of canon law. ${ }^{331}$ In 1468 , the first councillor from the university was the dean and rector of the university, the noble astrologer and doctor of medicine Peter Gaszowiec. It seems, however, that of much greater importance to Krakow's ruling elite was the university professor John of Reguła, who assumed the office of councillor in $1482 .{ }^{332}$ As a councillor, he visited the sick who wanted to record their last will. ${ }^{333}$ His strong ties with the city are also evidenced by the fact that his will was included in the Liber Testamentorum. ${ }^{334}$ His future son-in-law, Lukas Noskowski from Mazowsze, who was

328 Antoni Gąsiorowski, "O mieszczanach studiujących na Uniwersytecie Krakowskim w XV wieku," in Aetas media, aetas moderna, 653-663.

329 "Constituit insuper sepedictus dominus Gotfridus ac prefecit Reuerendum virum dominum Petrum de Radolina virum utique elegantissimum, iuris vtriusque doctorem ac ad Cracouiensem ecclesiam predictam postulatum, ac Magnificum Spitconem Palatinum et Capitaneum, necnon Consules Ciuitatis eiusdem predictos, qui sunt aut fuerint in futurum, presentis sui testamenti ac voluntatis sue vltime suos veros procuratores, factores, actores et executores legitimos atque certos"; KDWac., vol. 2, no. 396.

33 CONS. 428 , fol. 402.

$331 \quad$ KDMK, vol. 3, no. 474 .

$33^{2}$ Zdzisław Noga, Urzędnicy miejscy Krakowa, part 2: 1500-1794 (Krakow: Wydawnictwo Naukowe Uniwersytetu Pedagogicznego, 2008), XXI.

333 In 1482 he probated the will of Susan Mathis Beckinne, in 1484 that of Catherine Jorge Goltsmidinne, in 1487 that of Hedwig Granoszowa, in 1492 that of Jarosz the tailor, and in 1493 that of George Monczer; LT, fol. 135, 142-143, 145, 51-152, 153 .

334 For more on John from Reguły and his will cf. Urszula Sowina, Kazimierz Pacuski, Testamenty mieszczan krakowskich jako źródła, 433-446. 
born in Nałęcz, assumed the post of councillor in 1520, after finishing his university studies. ${ }^{335}$ In the sixteenth century, the number councilors who were 'doctors' increased to sixteen, ten of whom received the title in medicine and six in law. This trend continued in other centuries, which corresponds to the situation in many other European cities, including Cologne (where, however, it was primarily doctors of law who joined the ranks of the city's elite power structures). ${ }^{336}$ Meanwhile, the number of sons from wealthy Krakow families who were enrolled as students was growing. ${ }^{337}$ The growing social significance of a university education can be observed in the biographies of many of the most influential burghers, future Krakow councillors, in the late-fifteenth century, who were enrolled as students at the University of Krakow. ${ }^{338}$

\subsection{Social Capital-Quarter Captains, Tower Commanders and Administrators}

A burgher's importance, and the level of respect they commanded in society, was determined in large part by their participation in the official structures of government, the municipal council and the municipal bench court, and was also bolstered by membership of a guild as an elder (as discussed earlier in the chapter). Many testators served in these prestigious offices, which, alongside

335 Zdzisław Noga, Krakowska rada, 142-143.

336 Ibidem.

337 " [...] data concerning social status of the matriculated were only found for 83 persons. Among them, 57 students came from families that were part of the highest elite of the Krakow patriciate. Their fathers or relatives were members of the council, and their families acquired their financial position through trade, leasing salt mines and Krakow town tariffs. The most numerous families were the Morsztyn family (11 people), the Szwarc family (five people), the Krupka family (five people), and the Salomon family (six people). Three students each came from the Arnsberg, Koczwar, Teszner, Genkner families, while two each came from the Borek, Turzon, Bar, Scholtis and Kuncz families. Only one representative of the Becks, Bems, Brendelers, Brigers, Wiewiórkas, Noldenfessers, Longpeters, Orienths and Wolframs was confirmed in the university records. This is certainly not the entire list of all the members of the Krakow patricians who were ever admitted to the university. Among the remaining 26 persons, whose fathers' occupations were determined with more or less certainty, there is no prevailing profession. They include sons of tailors, furriers, shoemakers, belt makers, goldsmiths, herring traders, maltsters, fat producers, merchants, bag makers, cutlers and wheelwrights"; Krzysztof Boroda, Studenci Uniwersytetu Krakowskiego w późnym średniowieczu (Krakow: Wydawnictwo Avalon, 2010), 122-124.

338 The Album studiosorum Universitatis Cracoviensis features, among others, Kasper Gengner in 1462, John Kisling in 1463, Kasper Ber in 1470, John Haller since 1482, and, in the late fifteenth century, Jphn Turzon, Nicholas and Peter Solomon, George and John Morsztyn; Zdzisław Noga, Krakowska rada, 146-148. 
a burgher's financial situation, provides the best indication of their social position within the city. However, apart from these high stations, Krakovian testators also held other, less frequently mentioned city offices, that likewise testified to their social capital.

One interesting group in Krakow was the 'quarter captains' (in German Virtilsleute, and in Latin Capitaneos quartalibus, Seniores quartalium, Quartalenses, or Hominum quartaliorum), who were chosen for this office by the municipal council. ${ }^{339}$ In the first entry containing information about them (from 1396) in council books, it is noted that they were chosen 'by the streets' (per platheas). ${ }^{340}$ This may indicate that they were both residents of a given street and representatives of it in matters delegated to them by the municipal council. This is indicated by the above-mentioned entry, which states that particular streets in each quarter of the city were the responsibility of specific people. For example, in the pottery quarter, Langseidel was responsible for Franciscan Street; Bozemecz for Wiślana Street; Grudner for Jewish Street and John Voit for Shoemaker's Street. ${ }^{341}$ During the period up to 150o, information is given only fourteen times about the selection of quarter captains (in the years 1396, 1419, 1421, 1422, 1425, 1426, 1430, 1441, 1452, 1461, 1464, 1469 and 1473); however, on the basis of these entries and other notes in which they are mentioned, it can be assumed that in one form or another this function was performed by these persons throughout this period. Their task was to adjudicate simple disputes related to urban plots of land, the buildings on them, and the walls and canals that separated them from one another. ${ }^{342}$ As many as 43 Krakow testators as well as nine people who wrote wills that have been lost are found on lists of quarter captains in council books. In addition, it has been possible to identify the names of six quarter captains who made separate dower bequests for their wives, six who made mutual bequests with their wives, one

339 CONS. 427 , fol. 68.

340 "Capitaneorum ad quartalia Civitatis per platheas singulas constituti, feria secunda proxima post festum Beatorum Viti et Modesti martirum. Anno domini MCCCXCVI nunc currente per dominos consules Anni illiusdem"; cons. 427, fol. 68.

341 "Quartale Castrense: In plathea Castrj a Circulo usque ad Ecclesiam Sti Petri Tylo Zatheler, Henricus Parchowicz; et ab Ecclesia Sti Petri ulterius usque ad Valuam: Iacussius maritus Wercholmine, Petrus Cadner; Quartair figulorum: In plathea minorum, Langseidel, Wysle: Bozemecz Iudeorum Grudner, Sutorum Hannus Voyt; Quartale Slawcoviense: Stephanus, Hannus de Scawin, Slavcoviensis: Oderberg Iohannis, Hano Hesse et Iorge Deuczulrich; Quartale Carnificum: Floriani, Miczko Smersneyder et Tempilvelt, Hospitalis Valhenne; Carnificum: Degin et Petir Bemisch"; cons. 427, fol. 68.

342 E.g. the case of a wall between two houses built by Peter Graser, Cons. 428, fol. 274; the case of the gutter between the houses of Hannus Borg and Wilhelm at Bracka Street, CONS. 428 , fol. 319 . 
who made a bequest to his wife, and one who made a pious bequest. All in all, the above-mentioned group accounted for nearly half of all the people we know who held this function. Among them were 32 Krakow councillors (those sitting at the time on the municipal council or as aldermen on the bench court), fourteen further aldermen and 20 other influential burghers, most of whom were recruited from among wealthy Krakovian guild elders. The institution of quarter captain, which probably did not have any major significance for or influence on the shape of the city's political order, is, however, an interesting example of the existence of a kind of informal urban elite, which was not limited solely to councillors and aldermen. As a group exercising certain judicial powers, quarter captains were chosen from among rich and influential burghers, including both those who also sat on the municipal council and bench court, as well as others who were not members of these bodies. Initially, capitanei quartalium may have been meant to represent the citizenry of Krakow as a whole. For example, among all those serving as quarter captains in 1396, two acted as representatives of the Krakow community (as opposed to the city council) in 1408 after an anti-Jewish pogrom. ${ }^{343} \mathrm{~A}$ preliminary analysis of quarter captains as a group shows an ever-increasing number of councillors holding this position year to year. ${ }^{344}$ In result, over the course of the fifteenth century, this municipal function was dominated by the city council.

Another valuable example of a group of individuals invested with special trust (and thus social prestige) by the burghers are those who were responsible for crucial elements of the city's defence: the iron chains securing Krakow's streets (an element of the security system inside the city) and the towers in the city walls. In the first case, in 1421, 63 people are listed (two of these have been crossed out) as having been entrusted with padlocks to the chains securing particular streets in the city. This group includes both councillors and aldermen, as well as people who did not hold these positions (including some of the above-mentioned quarter captains). ${ }^{345}$ Although the first (lost) book of wills was probably still being kept at that time, we have information about the wills made by some of these people and, in individual cases, the wills themselves, which were entered in the books of the bench court. ${ }^{346}$

343 Peter Cadner, Peter Valhenne and John Steynbach, who was a quarter guard in 1422; CONS. 427 , fol. 278,311 .

344 There were no councilors among the quarter captains in 1396 and 1419, although some were wealthy; in 1441 councilors comprised at least half of them, and in 1473 most of them.

345 "Secuntur qui habent seras ad cathenas statuarum in platheis"; cons. 428, fol. 164.

346 E.g. of Nicholas Opoczko, SCAB. 6, fol. 110, 111 or alderman and councillor Ederer (Oderer), SCAB.,1676. 
Valuable information has been preserved in council books about commanders of city towers and gates (capitanei turrum et valvas Civitatis), ${ }^{347}$ including lists of commanders of city towers from the years 1410, 1414, 1422, 1430 and $1473 .{ }^{348}$ In the event of danger, two or four (perhaps depending on the size of the area) trusted burghers from among Krakow's citizenry were entrusted with commanding the defence of a tower and the adjacent parts of the walls. In the census of 1473, it is indicated which parts of Krakow's walls should be guarded by craftsmen from specific guilds. ${ }^{349}$ The appointed tower commanders, however, were not acting as representatives of the guild, but - as in the other cases discussed above - belonged to an elite group of burghers endowed with the highest level of authority and trust within the city, and who were often members of the municipal council, bench court or influential Krakovian families. It is worth noting that although in the 1410 census current or former councillors constitute the vast majority of such individuals, they are only found sporadically in later censuses - for example, in 1430 there were four councillors, and in 1473 none. However, in each of the five preserved entries, one can easily find many people who made wills or other types of bequests in the event of their death.

An individual's social capital can also be evidenced by prestigious functions performed in their religious community, such as holding the office of parish treasurer (in Latin vitricus ecclesiae) or church and hospital lay administrator (provisor), having patronage over a chapel or altar in a church, or serving in a senior position in one of Krakow's religious brotherhoods. ${ }^{350}$ Records of numerous wills written by such councillors have survived. These include wills by Kacper Krugil, the Carmelite Monastery's treasurer, Peter Graser, the administrator of the Holy Spirit Hospital (he also made a mutual bequest with his wife and donated rent to the brotherhood in the Church of the Holy Virgin Mary) and Peter Kaldherberg, the treasurer of St. Mary's Church. The administrator of this church was the alderman Michael the goldsmith (Michil goltsmed or Michael aurifaber), whose will has survived to our times. The very wealthy burgher Bartholomew Melczer, one of the administrators of the Holy Spirit Hospital, who in 1425 also served as its treasurer, also made a testamentary

347 The first of the preserved lists date back to 1410 and was probably written following the outbreak of the Polish-Teutonic War: "Feria secunda die sancte Egidii 1410, Nota infrascripti sunt ad Turres Civitatis et valvas Capitanei electi"; cons. 427 , fol. 378. CONs. 427 , fol. 378 ; CONs. 428 , fol. 66 , 188-189, 272; CONS. 429 , fol. 485 .

349 Cons. 429, fol. 485 .

$35^{\circ}$ Agnieszka Bartoszewicz, Warta, spoteczeństwo miasta w II połowie XV i na początku XVI wieku (Warszawa: Wydawn. Fundacji Historia pro Futuro, 1997), 131. 
bequest to his wife and stepdaughter. In Krakow, as in many other large cities in late medieval Europe, the municipal council began in the latter half of the fourteenth century to assume its authority over the city's religious institutions. This was connected, on the one hand, with the growing independence of the municipal authorities, and, on the other, with the perception of the city community and its market, stalls, gates, and churches as a single organism, whose functioning the councillors worked to ensure and maintain. In the literature on the subject, it is common to describe this phenomenon as religion civique, ${ }^{351}$ 'urban religiosity,'352 or 'communal religiosity.'353 During the fifteenth century, the council managed to assert its sole guardianship over urban churches, and thus the position of treasurer or administrator in the city's churches was usually held by designated councillors. ${ }^{354}$

\section{Changes in Social Position}

Statistical research on the wealth and social position of testators enables a better understanding and characterisation of the group of Krakow burghers who for various reasons showed the most interest in drawing up an act of last will. The image obtained from a reconstruction of Krakow's social structure reflects quite well the domination of the richest burgher-testators over their less wealthy fellow-townsmen. This kind of analysis, however, does not help us recognize or understand the dynamic character of the 'social position' occupied by such individuals over the course of their lives or the multi-faceted nature of the factors that influenced it. Only a closer look at individual wills and an

351 Trevor Dean, The Towns of Italy in the Later Middle Ages (Manchester: Manchester University Press, 2000), 63-71.

352 Halina Manikowska, Religijność miejska, in Ecclesia et civitas. Kościót i życie religijne w mieście średniowiecznym, ed. Halina Manikowska, Hanna Zaremska (Warszawa: Instytut Historii PAN, 2002), 11-34.

353 Marek Słoń, Religijność komunalna, 9-21.

354 Church treasurers among the councillors included Nicholas Gemlich (the treasurer of the 'New Monastery'), Kacper Krugil (Carmelite Monastery), Martinus Belze and Nicholas Kezinger (St. Bernard's Church), Peter Graser (Hospital of the Holy Spirit) and Peter Kaldherberg and Nicholas Zalcz, who were treasurers at the Blessed Virgin Mary Church at the market square in Krakow. Other aldermen and burghers who acted as church treasurers and administrators included John Smed, Alex, Nicholas carpentarius, Bartholomeus Melczer, Michael the goldsmith and Nicholas Kazimirski; cons. 427, fol. 401 (1411), 405 (1411), 409 (1411); CONS. 428, fol. 467 (1444); CONS. 429, fol. 324 (1463), 568 (1476); SCAB. 4, fol. 70 (1412); SCAB. 5, fol. 97 (1424), 106 (1425); SCAB. 6, fol. 245 (1441), 281 (1443), 357 (1446); SCAB. 8, fol. 293 (1466). 
attempt at a partial reconstruction of the lives of those who made them can reveal the weaknesses of using dower bequests as the sole means for determining the social status of Krakovian burghers. It also allows us to see that while we rarely encounter a situation in which an individual suddenly experiences social advancement or a decisive decline in standing, transition to a higher or lower status in terms of wealth during a burgher's lifetime was quite common. Both quantitative and qualitative research have their limitations and weaknesses, so it seems that only a combination of these two research methods will allow us to obtain a richer and more nuanced picture of the social reality of late medieval Krakow.

\subsection{The Dower and Level of Wealth}

Although in most cases dower bequests seem to provide a good indication of the financial situation of Krakovian burghers, like other types of sources, they cannot be approached uncritically. An interesting case here is the last will of the shoemaker Nicholas Mewsil in which the dower bequest does not seem to accurately reflect the testator's wealth or the amount of inheritance due to the wife. Mewsil's will was entered into the Liber Testamentorum in 1458.355 Defined by the councillors as 'our citizen' (unsir mitburger), Mewsil obtained Krakow citizenship on Christmas Eve $1415,{ }^{356}$ and as early as 1422 served as an elder in the Krakow shoemakers guild. ${ }^{357} \mathrm{He}$ also held this position in 1434 and $1439 .{ }^{358}$ In 1425, he bought from John Weigant a house on Wide Street, next to the Dominican monastery. ${ }^{359}$ He sold this property in 1436 (the house was already rented at that time for 36 groszy to the Church of All Saints). ${ }^{360}$ In 1456, it was reported that he owned a house on St. Florian Street. ${ }^{361}$ Moreover, in municipal books he appears once (in 1431) as a guarantor for the wife of another shoemaker from Krakow, ${ }^{362}$ twice as a witness in a case related to the care of orphans (1435 and 1441$)^{363}$ and once as the court representative of Anna Weinbrotinne, widow of the shoemaker John Weinbrot. ${ }^{364}$ Given this high level of social activity, it is surprising the testator's last will and testament

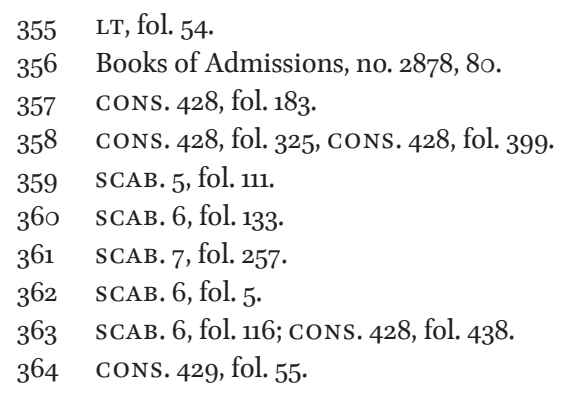


contains a bequest of only ten grivna as a dower for his wife Margaret, which was to be paid to her from the sale of her inheritance "or other acquired goods. ${ }^{365}$ In addition, she was to receive all the family's household furnishings. The rest of the estate was to be divided between his wife, his son Gabriel and his daughter Appolonia, with the exception of a shoemaker's bench and related equipment, which was intended for his daughter Justine. The will was confirmed by his wife Margaret, son Gabriel and daughter Justine, together with her husband George Fleischenbrot. ${ }^{366}$ In the light of other information gathered about this testator, it can be assumed that such a small bequest in the will may be a trace of the low level of affluence of Nicholas Mewsil at the time he married Margaret (perhaps shortly after obtaining citizenship of the city in 1415). The forty-three years that had passed since then and information we have about his life testify to his social and economic advancement, while the actual bulk of the inheritance his wife Margaret was to receive came from the third of the estate that she was to be given.

The case of the maltster and innkeeper John Specht is an example of how the size of the dower could depend on the wealth of the wife's family and the emotional factors binding her to her spouse, rather than on the economic situation of the testator himself. After obtaining Krakow citizenship in 1424, Specht was listed as a maltster from the Lower Silesian town of Przemków. ${ }^{367}$ His move to Krakow might have been facilitated by another, perhaps related, John Specht, who became a Krakow citizen in 1417, and in 1423 and 1425 was already serving in the position of elder in the belt makers guild. ${ }^{368}$ The first mentions of the malster John Specht in municipal books date back to 1433 and 1435, when he appeared in a census of guild elders as one of the chosen elders of the innkeepers guild. ${ }^{369}$ His quick integration into the structure of Krakow society and his professional advancement allowed him to buy a house in 1437 on a plot located on the corner of Hospital Street. ${ }^{370}$ Two years later, in 1439, he is listed as being a elder in the maltsters' guild. ${ }^{371}$ At about that time, now a respected citizen of the city, he began to act as both the executor of the wills of Margaret

\footnotetext{
365 "[...] also dassy meyn erbe do ich ynne wone noch meynem tode vorkewfen sollen, und von dem gelde adir aus ander meynen gewissen guttern folgen sal"; LT, fol. 54.

366 What is remarkable here are the unusual names of Mewsil's children: Appolonia, Gabriel and Justine, which in a way point to his broader intellectual horizons.

367 Book of Admissions, no. 3684, 105.

368 sCAB. 5, fol. 193, 217.

369 Cons. 428 , fol. 316,336 .

370 SCAB. 6, fol. 137 .

371 CONS. 428 , fol. 399.
} 
Lechlerinne (1439 and 1442), ${ }^{372}$ innkeeper Peter Warzigarnek (1450) ${ }^{373}$ and Margaret Grobniginne (1460), 374 and as the attorney of Barbara Fornalin during the sale of her house (1442). ${ }^{375}$ When in 1451 the councillors detected fraud being committed by innkeepers serving beer, he was appointed as a trusted individual to be one of the commissioners investigating the quality of the city's beer. ${ }^{376} \mathrm{He}$ may also have gone on a jubilee pilgrimage to Rome in 1450, the year in which he made his last will before the municipal bench court, together with other burghers who were going on pilgrimages. In the will, he bequeathed all his possessions to his wife Barbara and son John, to be divided equally, and stated that if his son died childless first, his property should be given to his more distant relatives after his wife's death. ${ }^{377}$ The testator returned safely from the pilgrimage, but it seems that soon afterwards he had to deal with the death of his son, because four years later, in 1454, he and his wife Barbara bequeathed all of their property to one another in the event of the death of one of them. ${ }^{378}$ However, John also survived his wife Barbara, and after some time, now quite old, remarried, this time to a Margaret, who is mentioned in his will of 1466. This was a notable year because during it Krakow was stricken by plague, which sowed terror among its inhabitants. John Specht, most likely out of a fear of dying - though he was apparently not ill himself - decided to write his will before other councillors. ${ }^{379}$ He divided most of his estate among Krakow's hospitals (five florins for St. Valentine's, ten florins for St. Hedwig's and 30 florins for St. Spirit's) and for food for the Bernardine brothers (20 florins). However, he bequeathed only 20 grivna to his wife, Margaret, and did not mention any other relatives save for his nephew, Melchior the shoemaker (Malchar des schuster), who he made an executor of his will. One year after the epidemic ended, however, he revoked the will on account of having sold the house on Hospital Street (to the alderman and later councillor Paul Ber). ${ }^{380}$ The last version of John Specht's will was made (this time before the bench court) in $1469 .{ }^{381}$

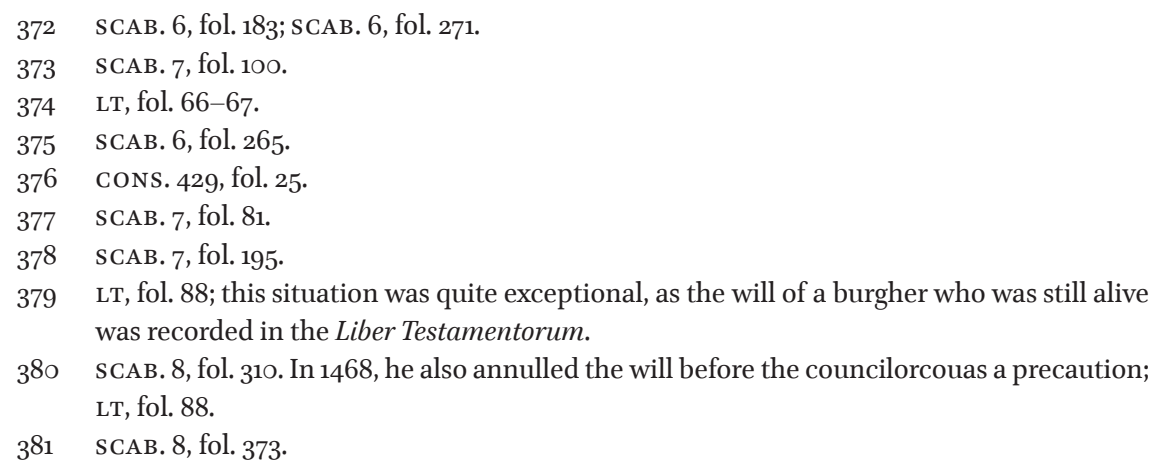


In accordance with law and custom, he asked whether he could dispose of his acquired (and not inherited) property according to his will and, after obtaining approval from the bench court, handed over to them his will written on a piece of paper. In it he repeated part of his previous will's provisions, giving his wife 20 grivna as a dower and making bequests to the same institutions he had previously endowed. This time, however, after the sale of the house, his pious bequests were much more generous. He contributed once again mainly to Krakow's hospitals: 30 florins to the women in Holy Spirit, 30 florins to the poor in St. Hedwig's, 10 florins to the poor in St. Valentine's and ten florins to St. Leonard's Hospital. He also donated to the Bernardines (4o florins for food), and the Bernardine Sisters from St. Agnes (10 florins for food). In this version of the will he also included the children of his nephew Melchior, to whom he bequeathed 20 florins, provided that Melchior would help him and work for him (her dy notczen und do mitte arbitten sal). Other relatives were excluded from the inheritance. John Specht died at a very old age, as evidenced by the fact that it was not until 1476 that his wife Margaret received from the will's executors the 20 grivna due to her. Specht's story is both an interesting example of a burgher's life and the social advancement he made, as well as providing proof of the extent to which in certain justified cases the dowry no longer reflected the social and financial status of the testator. Having married once again, this time to a woman who was poorer than himself, John Specht was legally obliged merely to secure for her a relatively modest dower (which corresponded to the dowry she brought to the marriage). It can be assumed that due to a lack of strong emotional ties with his new wife, he chose to focus his bequests on Church institutions and his more distant relatives than to use his money to secure the economic situation of his wife after his death.

Due to the nature of the dower itself, as a form of compensation and security for the dowry provided earlier by the wife, a new marriage to either a better- or poorer-situated spouse could change its amount. However, there is no shortage of examples where even in the case of a marriage to the same woman, especially in the absence of offspring - the natural heirs to the estate - the size of the dowry could be increased significantly. A good example of this is the figure of John Lode, who made his first will in 1439 before going on a pilgrimage to Rome. ${ }^{382}$ Arguing that this step was intended to avoid family disputes about the property he would leave behind, he bequeathed to his wife Margaret 50 florins, and to his underage brother Nicholas ten florins, along with all his

382 The date of the will is unknown. It could have been written in 1439, according to its place in the Liber Testamentorum, but in several cases, in the first part of the book, the order of the registered wills is distorted; $\mathrm{LT}$, fol. 10. 
personal belongings. He donated the rest of his property to St. Mary's Church, Holy Spirit Hospital, the Franciscan brotherhood, ${ }^{383}$ and to help 'poor people.' In 1454 John and Margaret made a mutual bequest of all of their goods, ${ }^{384}$ and two years later, in 1456, John Lode, "going to the Turks who did not know the Christian faith" and counting on the possibility of death among these 'heathen,' this time bequeathed as much as 100 florins to his wife Margaret, and ten more florins to his brother Nicholas Lode of Plzeň, when he reached adulthood. Of the previous pious bequests, there remained only the donation of ten florins to the Krakow hospital. It may be assumed that in this case, the doubling of the dowry to his wife Margaret was not connected with a corresponding doubling of the testator's estate, but, above all, with their lack of children and the husband's entrusting the salvation of his soul to his wife (as evidenced by the much more modest pious bequests made in the second version of the will).

\subsection{Social Mobility}

In analysing the social position of Krakovian testators, one's efforts can be frustrated by encounters with enigmatic and incomplete information about the assets contained in wills or by an over-reliance on the size of dower bequests. It is likewise risky to base one's work on a single will produced by a given individual as a means of determining his or her economic and social capital. In the case of those testators for whom prosopographic research yields a larger volume of data, one generally sees changes in their social position over the course of their lives. ${ }^{385}$

Social advancement can be seen, for example, in the case of the poor oil seller John Noga. In 1442, he bought from Peter the oil seller a house behind St. Stephen's Church with a rent of sixty groszy, ${ }^{386}$ and then, in the same year, bequeathed a dower of 30 grivna to his wife Dorothy. ${ }^{387}$ When he wrote his will in 1464 , he already owned two houses behind St. Mark's Church, ${ }^{388}$ one of which was shared with his son by his second wife, Catherine, while the other was sold for 6o grivna by the executor of his son's will (who was also called John Noga the oil seller). ${ }^{389}$

\footnotetext{
383 This refers to the brotherhood in the so-called Hungarian chapel in St. Francis Church; Hanna Zaremska, Bractwa, 81-83.

384 SCAB. 7 , fol. 195 .

385 Roman Czaja, "Społeczna mobilność jako paradygmat badań nad patrycjatem i grupami kierowniczymi w średniowieczu," in Elita wtadzy miasta Krakowa, 9-21.

386 SCAB. 6 , fol. 258 .

387 SCAB. 6 , fol. 269 .

388 sСАв. 8, fol. 177 .

389 CONS. 429 , fol. 545 .
} 
Szymek from Jewish Street can also be counted among the group of Krakow burghers who became wealthy as a result of their own labour. He confirmed his will before a bench court, where, according to custom, he asked if "he could dispose of his earned wealth in accordance with his will, namely, if he wishes, to give one child more than to others or to another, depending on his merits" (uni puero plus dando quam aliis vel alio iuxta erga eum plus merito). After receiving a positive answer from the bench court, he handed over his will, written on a piece of paper, which was then entered into the court's book. ${ }^{390} \mathrm{He}$ began with a bequest of ten grivna to his wife Dorothy, to which he added 20 more grivna and secured this with his property, in particular his house on Jewish Street and by the garden in front of Szewska Gate. This significant increase in the size of the dower (melioracio dotalicii) was justified by the fact that her money helped to pay off the house rent of two grivna, with which it had been burdened. Szymek bequeathed 20 grivna to each of his three children, who were also to inherit in equal parts what remained after the sale of the property. This will was accompanied by an interesting note, which shows that after the testator's death the widow was repaid 30 grivna by Stanisław, a son from Szymek's first marriage. The note also states that Stanisław gave 20 grivna to Dorothy, Szymek's daughter, and five grivna to Barbara, a maid not mentioned in the will. The testator, despite his initial low social status (which may be indicated by the ten grivna he originally bequeathed as a dower), significantly increased his estate, since in his will he had assets worth almost 100 grivna (of which his wife was entitled to 30 ). Information about the testator's second marriage and the fact that his new wife (perhaps from her dowry or inheritance money) had paid off the encumbrance against their home also sheds more light on this will. The increase in her dower was equal to the amount needed to pay off the rent. This will is undoubtedly an interesting example of how successive marriages could contribute to the accumulation of economic capital, even among relatively low-income burghers. While entering into a favourable marriage could significantly influence the social advancement of even a not-very-wealthy burgher, in the case of wealthy individuals belonging to the social elite, it must have had an even more significant impact. ${ }^{391}$

390 SCAB. 8, fol. 202.

391 The previously mentioned alderman Peter Schepcz is a good example. The goods he inherited from his first wife, Dorothy, are evidenced by the very valuable clothes and ornaments mentioned in his will. These were supposed to be given to his daughters from his first marriage. The assets brought by his second wife Jadwiga point to the very large dowry she received, which was at least the equivalent of the dower she was given. What is more, after they married, Peter came into even more wealth when his wife Hedwig received an inheritance from her parents from the town hall in 1477; cf. LT, fol. 137-140; CONS. 428 , fol. 585 . 
Analysing the wills described above, we see the dynamic and complex nature of the position occupied by an individual within a social group and the many elements affecting this situation which are difficult to discern by means of quantitative research. A highly significant factor influencing the accumulation of economic capital among burghers was their successive - very often two or three - marriages. Well-considered marriage contracts played a greater role primarily among members of Krakow society's upper class (as evidenced by, among other things, the size of dower bequests entered into municipal books), but there is no doubt that for less wealthy burghers this could also have provided a means by which to significantly increase their wealth and thus improve their social situation. ${ }^{392}$

The gathered data indicate that wills as 'tools of power' could have played an important role in the burgher's individual strategies of securing and improving their social position. A variety of testamentary practices, including securing marriage contracts, management of goods accumulated during lifetime, disinheriting distant relatives, as well as popular reciprocal clauses between spouses, allowed and supported the accumulation of goods within urban families. All of these testamentary practices had an impact on a general social mobility in the city. However, as indicated by the analyzed wills, these 'tools' were used primarily by members of the most privileged groups, in which the surplus of capital facilitated its further multiplication.

The complexity of Krakovian wills, written for various reasons, in different ways and during different periods during the lifetime of the testator, means that any estimates of individuals' financial situation and comparisons made between wills must be made with great care. In only a few cases have several versions of the wills written by a single burgher been preserved; more cases like these would have made it possible to better understand both the circumstances surrounding the writing of wills in this period and the changes in the economic and social situations of the testators involved.

392 Zdzisław Noga, Grupy zawodowe, 253-263. 